\title{
Characteristics, sources, and transport of aerosols measured in spring 2008 during the aerosol, radiation, and cloud processes affecting Arctic Climate (ARCPAC) Project
}

\author{
C. A. Brock ${ }^{1}$, J. Cozic ${ }^{1,2,{ }^{*}}$, R. Bahreini ${ }^{1,2}$, K. D. Froyd ${ }^{1,2}$, A. M. Middlebrook ${ }^{1}$, A. McComiskey ${ }^{1,2}$, J. Brioude ${ }^{1,2}$, \\ O. R. Cooper ${ }^{1,2}$, A. Stohl ${ }^{3}$, K. C. Aikin ${ }^{1,2}$, J. A. de Gouw ${ }^{1,2}$, D. W. Fahey ${ }^{1,2}$, R. A. Ferrare ${ }^{4}$, R.-S. Gao ${ }^{1}$, W. Gore ${ }^{5}$, \\ J. S. Holloway ${ }^{1,2}$, G. Hübler ${ }^{1,2}$, A. Jefferson ${ }^{1}$, D. A. Lack $^{1,2}$, S. Lance ${ }^{1,2}$, R. H. Moore ${ }^{6}$, D. M. Murphy ${ }^{1}$, A. Nenes ${ }^{6,7}$, \\ P. C. Novelli ${ }^{1}$, J. B. Nowak ${ }^{1,2}$, J. A. Ogren ${ }^{1}$, J. Peischl ${ }^{1,2}$, R. B. Pierce ${ }^{8}$, P. Pilewskie ${ }^{9}$, P. K. Quinn ${ }^{10}$, T. B. Ryerson ${ }^{1}$, \\ K. S. Schmidt ${ }^{11}$, J. P. Schwarz ${ }^{1,2}$, H. Sodemann ${ }^{3, * *}$, J. R. Spackman ${ }^{1,2}$, H. Stark ${ }^{1,2}$, D. S. Thomson ${ }^{1,2, * * *}$, \\ T. Thornberry ${ }^{1,2}$, P. Veres ${ }^{1,2}$, L. A. Watts ${ }^{1,2}$, C. Warneke ${ }^{1,2}$, and A. G. Wollny ${ }^{1,2, * * * *}$ \\ ${ }^{1}$ Earth System Research Laboratory, National Oceanic and Atmospheric Administration, Boulder, Colorado, USA \\ ${ }^{2}$ Cooperative Institute for Research in Environmental Sciences, University of Colorado, Boulder, Colorado, USA \\ ${ }^{3}$ Norsk Institutt for Luftforskning, Kjeller, Norway \\ ${ }^{4}$ Langley Research Center, National Aeronautics and Space Administration, Hampton, Virginia, USA \\ ${ }^{5}$ Ames Research Center, National Aeronautics and Space Administration, Moffett Field, California, USA \\ ${ }^{6}$ Chemical and Biomolecular Engineering, Georgia Institute of Technology, Atlanta, Georgia, USA \\ ${ }^{7}$ Earth and Atmospheric Science, Georgia Institute of Technology, Atlanta, Georgia, USA \\ ${ }^{8}$ National Environmental Satellite, Data, and Information Service, National Oceanic and Atmospheric Administration, \\ Madison, Wisconsin, USA \\ ${ }^{9}$ Atmospheric and Oceanic Sciences, University of Colorado, Boulder, Colorado, USA \\ ${ }^{10}$ Pacific Marine Environmental Laboratory, National Oceanic and Atmospheric Administration, Seattle, Washington, USA \\ ${ }^{11}$ Laboratory for Atmospheric and Space Physics, University of Colorado, Boulder, Colorado, USA \\ * now at: Laboratoire de Glaciologie et Géophysique de l'Environnement, Grenoble, France \\ ** now at: Institute for Atmospheric and Climate Science, ETH Zurich, Zurich, Switzerland \\ ${ }^{* * *}$ now at: Droplet Measurement Technologies Inc., Boulder, Colorado, USA \\ ***** now at: Biogeochemistry, Max Planck Institute for Chemistry, Mainz, Germany
}

Received: 8 October 2010 - Published in Atmos. Chem. Phys. Discuss.: 11 November 2010

Revised: 28 January 2011 - Accepted: 4 March 2011 - Published: 16 March 2011

\begin{abstract}
We present an overview of the background, scientific goals, and execution of the Aerosol, Radiation, and Cloud Processes affecting Arctic Climate (ARCPAC) project of April 2008. We then summarize airborne measurements, made in the troposphere of the Alaskan Arctic, of aerosol particle size distributions, composition, and optical properties and discuss the sources and transport of the aerosols. The aerosol data were grouped into four categories based on gas-phase composition. First, the background troposphere contained a relatively diffuse, sulfate-rich aerosol extending from the top of the sea-ice inversion layer to $7.4 \mathrm{~km}$ altitude. Second, a region of depleted (relative to the background) aerosol was present within the surface inversion
\end{abstract}

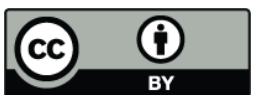

Correspondence to: C. A. Brock (charles.a.brock@noaa.gov) layer over sea-ice. Third, layers of dense, organic-rich smoke from open biomass fires in southern Russia and southeastern Siberia were frequently encountered at all altitudes from the top of the inversion layer to $7.1 \mathrm{~km}$. Finally, some aerosol layers were dominated by components originating from fossil fuel combustion.

Of these four categories measured during ARCPAC, the diffuse background aerosol was most similar to the average springtime aerosol properties observed at a long-term monitoring site at Barrow, Alaska. The biomass burning (BB) and fossil fuel layers were present above the sea-ice inversion layer and did not reach the sea-ice surface during the course of the ARCPAC measurements. The BB aerosol layers were highly scattering and were moderately hygroscopic. On average, the layers produced a noontime net heating of $\sim 0.1 \mathrm{~K} \mathrm{day}^{-1}$ between 3 and $7 \mathrm{~km}$ and a slight cooling at the surface. The ratios of particle mass to carbon monoxide (CO)

Published by Copernicus Publications on behalf of the European Geosciences Union. 
in the BB plumes, which had been transported over distances $>5000 \mathrm{~km}$, were comparable to the high end of literature values derived from previous measurements in wildfire smoke. These ratios suggest minimal precipitation scavenging and removal of the BB particles between the time they were emitted and the time they were observed in dense layers above the sea-ice inversion layer.

\section{Introduction}

Global temperature records show a statistically significant warming in the last century, with most of the change attributed to anthropogenically emitted greenhouse gases and associated feedbacks (IPCC, 2007). Temperature increases in the Arctic exceed the global average increase, especially in winter and spring. Coincident with the observed and modeled warming is an observed decrease in seasonal Arctic sea-ice coverage and thickness. The summertime extent of sea-ice has decreased significantly in recent decades (Lindsay et al., 2009), and this reduction now clearly exceeds that expected from natural short-term variability (Francis and Hunter, 2006; Johannessen et al., 2004; IPCC, 2007; Holland et al., 2010). Many climate models predict an ice-free summertime Arctic Ocean within a few decades (Winton, 2006; Stroeve, 2007; Holland et al., 2010), with attendant disruptions to Arctic ecosystems, ocean circulation, weather patterns, and global climate. Additional effects of a warmer Arctic may include substantial expansion of resource extraction and seasonal shipping traffic due to improved sea access (Corbett et al., 2010).

Modeling of the Arctic climate system is difficult due to complex and sensitive feedbacks (Serreze and Francis, 2006) and many climate simulations struggle to replicate historical temperature, precipitation, cloudiness, and sea-ice properties (Walsh et al., 2002; Chapman and Walsh, 2007; Wang et al., 2007). Simulations of future climates result in substantial model-to-model variability in Arctic climate parameters such as sea-ice extent and thickness, indicating that some important processes are not being adequately described in the simulations (Winton, 2006; Chapman and Walsh, 2007; Holland et al., 2010).

Analyses of observations and recent climate simulations suggest that, in addition to long-lived greenhouse gasinduced warming and feedbacks, Arctic warming may also be caused by shorter-lived climate forcing agents (Law and Stohl, 2007; Quinn et al., 2008; Shindell et al., 2008; Shindell and Faluvegi, 2009). In particular, four processes have been postulated to contribute significantly to observed atmospheric warming and reductions in sea-ice in the Arctic. These processes include: (1) direct warming of the lower troposphere by the absorption of solar radiation and infrared (IR) emission by aerosol particles (e.g., Ritter et al., 2005; Treffeisen et al., 2007; Shindell and Faluvegi,
2009); (2) changes in snow melt and surface temperature due to deposition of soot (containing light-absorbing black carbon, $\mathrm{BC}$ ) to the surface in springtime (Hansen and Nazarenko, 2004; Jacobson, 2004, 2010; Flanner et al., 2007, 2009); (3) increases in IR emissivity of wintertime and springtime clouds in the Arctic due to the effects of anthropogenic aerosol particles on cloud properties (Garrett and Zhao, 2006; Lubin and Vogelmann, 2006; Alterskjær et al., 2010); and (4) direct radiative effects of tropospheric ozone in the Arctic (Mickley et al., 1999; Hansen et al., 2005; Shindell and Faluvegi, 2009). Recent modeling studies suggest that the Arctic climate is particularly influenced by aerosol radiative forcing, and is sensitive to the composition, and hence optical properties, of the aerosol (Shindell and Faluvegi, 2009; Jacobson, 2010).

Airborne and surface observations in the Arctic have long reported the annual occurrence of visibility-reducing aerosol hazes in the Arctic in springtime (Shaw, 1975; Rahn, 1981; Barrie, 1986; Garret and Verzella, 2008; Stone et al., 2010). An extensive literature has documented the chemical and optical characteristics of these hazes (Schnell, 1984; Clarke et al., 1984; Radke, et al., 1984; Brock et al., 1990; see also http://www.agu.org/contents/sc/ViewCollection.do? collectionCode=ARCTHZ $\backslash$ \&journalCode=GL), and a climatology of some key parameters extending more than 20 years has been developed for a few Arctic sites (e.g., Quinn et al., 2002, 2007, 2009; Sharma et al., 2002, 2004, 2006). The springtime submicron aerosol at all remote Arctic surface sites is composed predominantly of partially neutralized sulfate and sea-salt, with lesser contributions from nitrate, BC, soil and trace elements (e.g., Quinn et al., 2002). There are few reported measurements of organic concentration or composition in the deep Arctic (Li and Winchester, 1989; Kawamura et al., 1996), and residual mass unaccounted for by comparing compositional measurements with gravimetric mass concentrations has been assigned to this component (Quinn et al., 2002). Recent measurements report that both anthropogenic and biomass/biofuel burning sources contribute to the organic aerosol fraction in the Arctic in spring (Shaw et al., 2010). There is a strong seasonal cycle to both intensive (e.g., type, size, composition, single scattering albedo) and extensive (e.g., mass and number concentration, light scattering) aerosol properties at surface sites throughout the Arctic, with one or more maxima in the late winter and early spring, and a pronounced minimum in the summer months (Bodhaine, 1989; Delene and Ogren, 2002; Quinn et al., 2002). There is some additional evidence for a slightly different seasonal cycle to Arctic haze properties aloft, with higher concentrations occurring aloft later in the spring than at the surface (Scheuer et al., 2003; Stohl, 2006). In addition, aerosol layers associated with BB sources have been observed in the Arctic troposphere in summer (Brock et al., 1989; Stohl et al., 2006; Paris et al., 2009); extreme BB events have been observed at the surface across much of the Arctic (Stohl et al., 2006). 
Because of the cold temperatures at the Arctic surface, the dominant sources contributing to the springtime maximum in Arctic surface aerosol concentrations lie in northern midlatitudes (Rahn and McCaffery, 1980; Raatz and Shaw, 1984; Barrie, 1986; Koch and Hansen, 2005; Stohl, 2006). Diabatic cooling produces large-scale descent of air from the middle to lower Arctic free troposphere (Stohl, 2006), although small-scale mixing processes may be needed to facilitate further transport to the sea-ice inversion layer (Spackman et al., 2010). Such cooling and mixing could result in transport of aerosol from slightly warmer midlatitude sources to the Arctic free troposphere and thence downward into the cold surface layer. However, on average, the largest contributions to the springtime surface aerosol in the Arctic are believed to come from northern Europe and the Russian Arctic, where large industrial complexes have long operated (Rahn et al., 1977; Rahn 1981; Raatz and Shaw, 1984; Barrie, 1986; Koch and Hansen, 2005; Sharma et al., 2006; Stohl, 2006). Due to declines in emissions from the former Soviet Union and eastern Europe, light scattering, light absorption, and black carbon concentrations have fallen in the Arctic in springtime since the 1980s, with a possible leveling or slight increase in the 21st century (Sharma et al., 2006; Quinn et al., 2007, 2009; Hirdman et al., 2010). Because most industrial sources in North America lie southward of the mean position of the Arctic front, and since advection from these sources to the Arctic involves transport through the meteorologically active North Atlantic region, North American sources are not believed to contribute more than occasionally to surface Arctic haze, and the North American influence is likely most pronounced in the vicinity of Greenland (Stohl, 2006; McConnell et al., 2007). Koch and Hansen (2005) suggest a significant contribution to springtime Arctic BC loadings from southern Asia, but Stohl (2006) and Hirdman (2010) find this source region to be only a small contributor to the Arctic BC budget. A few studies suggest that biomass burning, primarily associated with springtime agricultural activities, can be a sporadic but potentially important contributor to the budgets of Arctic gas-phase and aerosol species (Lavoué, et al., 2000; Stohl et al., 2007; Warneke et al., 2009, 2010).

In spring 2008, the United States (US) National Oceanic and Atmospheric Administration (NOAA) undertook a large airborne field campaign, the Aerosol, Radiation, and Cloud Processes affecting Arctic Climate (ARCPAC) study, primarily to evaluate phenomena and processes contributing to nongreenhouse gas climate forcing in the Arctic (http://www. esrl.noaa.gov/csd/arcpac). The ARCPAC project used the heavily instrumented NOAA WP-3D aircraft to make observations in the troposphere over northern Alaska and the adjacent Arctic seas. Four general topic areas were the foci of study: (1) improving understanding of the chemical, optical, and microphysical characteristics of aerosols in the Arctic in springtime; (2) evaluating the sources and sinks of the various aerosol components using observations of gas and particulate composition and transport models; (3) examining the role of aerosol particles in modifying the microphysical and optical properties of Arctic clouds and the role of those clouds in modifying and removing aerosol particles; (4) evaluating the occurrence and mechanisms of halogen photochemistry that leads to tropospheric ozone loss in the Arctic. Additional topics studied during the project included examining local emissions and cold-weather chemistry associated with urban areas and industrial facilities encountered in the Arctic, during flights in the Denver, Colorado area, and in transit between the aircraft base in Tampa, Florida and Fairbanks, Alaska. Emission, transport, and process modeling were recognized as essential tools to interpret the observations given the distance and transport time from likely sources. Further details of specific science questions and approaches employed in planning, executing, and analyzing the data from ARCPAC are listed in the Supplement in Table S1.

The ARCPAC project was one of several complementary activities associated with the International Polar Year (IPY) and coordinated through the Polar Study using Aircraft, Remote Sensing, Surface Measurements and Models, of Climate, Chemistry, Aerosols, and Transport (POLARCAT) program (http://www.polarcat.no/). The ARCPAC project overlapped in space and time with the springtime deployment of the US National Aeronautics and Space Administration (NASA)-sponsored Arctic Research of the Composition of the Troposphere from Aircraft and Satellites (ARCTAS) project (http://www.espo.nasa.gov/arctas/), which had many similar goals as ARCPAC but which covered a larger area of the Arctic (Jacob et al., 2010). Coordination between ARCPAC and ARCTAS included wingtip-to-wingtip comparisons with the NASA DC-8 and P-3B aircraft and simultaneous vertically stacked flight segments combining the NOAA WP-3D with the NASA P-3B and the lidar-equipped NASA B-200 aircraft (Bierwirth et al., 2010). The ARCPAC project also coordinated one flight segment in clear and cloudy air with the Convair 580 aircraft operated as part of the US Department of Energy/Canadian National Research Councilsponsored Indirect and Semi-Direct Aerosol Campaign (ISDAC), which focused on the meteorology, microphysics, radiation, and interaction with aerosols of near-surface clouds in the Alaskan Arctic (http://acrf-campaign.arm.gov/isdac/). The ARCPAC program was also linked with ship-borne observations made in the North Atlantic and European Arctic as part of the NOAA-sponsored International Chemistry Experiment in the Arctic LOwer Troposphere (ICEALOT) campaign (http://saga.pmel.noaa.gov/Field/icealot/).

The purpose of this paper is (1) to provide information on the scientific background and objectives, methods, and execution of the ARCPAC project, and (2) to summarize the aerosol chemical, microphysical, cloud-nucleating, and optical properties observed during the project. More detailed work on aerosol composition, aerosol radiative effects, cloud-aerosol interactions, long-range transport, aerosol deposition, gas-phase chemistry, the Arctic radiative environment, and Arctic emissions from the ARCPAC project can be 
Table 1. Instruments, uncertainties, references.

\begin{tabular}{|c|c|c|c|c|}
\hline Parameter & Method & Uncertainty & $\begin{array}{l}\text { Sampling } \\
\text { frequency }\end{array}$ & Reference \\
\hline $\begin{array}{l}\text { Size-resolved non-refractory aerosol composition, physical di- } \\
\text { ameters }<0.5 \mu \mathrm{m}\end{array}$ & $\begin{array}{l}\text { Compact time-of-flight aerosol mass } \\
\text { spectrometer (AMS) }\end{array}$ & $\begin{array}{l}34 \% \mathrm{NH}_{4}^{+}, \mathrm{NO}_{3}^{-} \\
36 \% \mathrm{SO}_{4}^{2-}, \mathrm{Cl}^{-} \\
38 \% \text { organics }\end{array}$ & $10 \mathrm{~s}$ & Bahreini et al. (2008) \\
\hline Single-particle refractory black carbon mass & $\mathrm{DMT}^{\mathrm{a}}$ single particle soot photometer & $40 \%$ & $1 \mathrm{~s}$ & Schwarz et al. (2006) \\
\hline Single particle composition & $\begin{array}{l}\text { Laser ablation/ionization mass spec- } \\
\text { trometer (PALMS) }\end{array}$ & not applicable & variable & Murphy et al. (2006) \\
\hline $\begin{array}{l}\text { Aerosol size distribution } 0.004-1.0 \mu \mathrm{m} \text { (fine), } \\
1.0-8.3 \mu \mathrm{m} \text { (coarse) }\end{array}$ & $\begin{array}{l}\text { Multiple condensation and optical par- } \\
\text { ticle counters }\end{array}$ & $\begin{array}{l}\text { number }_{-19}^{+22} \%, \\
\text { surface }_{-27}^{+36} \%,\end{array}$ & $\begin{array}{l}\text { fine-1 s } \\
\text { coarse- } 30 \mathrm{~s}\end{array}$ & $\begin{array}{l}\text { Brock et al. (2008); } \\
\text { Supplements }\end{array}$ \\
\hline & & volume ${ }_{-31}^{+45} \%$ & & \\
\hline Aerosol extinction $(532,1064 \mathrm{~nm}), \gamma(\mathrm{RH})$ & Cavity ringdown spectrometer & $\begin{array}{l}532 \mathrm{~nm}, \quad 0.5 \mathrm{Mm}^{-1}+2 \% \\
1064 \mathrm{~nm}, \quad 0.5 \mathrm{Mm}^{-1}+4 \% \\
\gamma(\mathrm{RH}),<16 \%\end{array}$ & $1 \mathrm{~s}$ & Baynard et al. (2007) \\
\hline Aerosol absorption $(467,530,660 \mathrm{~nm})$ & Particle soot absorption photometer & $\begin{array}{l}\text { calculated point-by- } \\
\text { point, } \sim 50 \%\end{array}$ & $1 \mathrm{~s}$ & Bond et al. (1999) \\
\hline Cloud condensation nuclei $(\mathrm{CCN})$ concentration & 1-channel DMT CCN counter & $\begin{array}{l}<17 \% \text { for concentra- } \\
\text { tion }>100 \mathrm{~cm}^{-3}\end{array}$ & $1 \mathrm{~s}$ & $\begin{array}{l}\text { Roberts and } \\
\text { Nenes (2006); Lance } \\
\text { et al. (2006) }\end{array}$ \\
\hline Liquid water content & Hot wire probes (King) & $10 \%$ & $1 \mathrm{~s}$ & King (1978) \\
\hline Cloud particle size distribution $(0.6-50 \mu \mathrm{m})$ & $\begin{array}{l}\text { Forward/back scattering: DMT } \\
\text { cloud and aerosol spectrometer }\end{array}$ & $\begin{array}{l}\text { did not function in } \\
\text { ARCPAC }\end{array}$ & $1 \mathrm{~s}$ & Baumgartner et al. (2001) \\
\hline Cloud particle size distribution $(3-50 \mu \mathrm{m})$ & $\begin{array}{l}\text { Forward scattering: DMT cloud droplet } \\
\text { probe }\end{array}$ & varies & $1 \mathrm{~s}$ & Lance et al. (2010a) \\
\hline $\begin{array}{l}\text { Cloud particle size distribution }(50-6000 \mu \mathrm{m}) \text {, } \\
\text { morphology }\end{array}$ & $\begin{array}{l}\text { DMT cloud imaging probe; precipita- } \\
\text { tion imaging probe }\end{array}$ & varies & $1 \mathrm{~s}$ & Lance et al. (2010a) \\
\hline Actinic fluxes (280-690 nm, up and down) & Spectral actinic flux radiometer & $\sim 15 \%$ & $1 \mathrm{~s}$ & Stark et al. (2007) \\
\hline Spectral irradiance (360-2200 nm, up and down) & Solar spectral flux radiometer & $3 \%$ & $1 \mathrm{~s}$ & Pilewskie et al. (2003) \\
\hline IR irradiance ( $4.5-42 \mu \mathrm{m}$, up and down) & Pyrgeometers & $5 \%$ & $1 \mathrm{~s}$ & Reda et al. (2002) \\
\hline Ozone $\left(\mathrm{O}_{3}\right)$ & NO chemiluminescence & $0.05 \mathrm{ppbv}+4 \%$ & $1 \mathrm{~s}$ & Ryerson et al. (1998) \\
\hline $\begin{array}{l}\mathrm{NO} \\
\mathrm{NO}_{2} \\
\mathrm{NO}_{\mathrm{y}}\end{array}$ & $\mathrm{O}_{3}$ chemiluminescence & $\begin{array}{l}0.02 \mathrm{ppbv}+8 \% \\
0.04 \mathrm{ppbv}+10 \% \\
0.05 \mathrm{ppbv}+12 \%\end{array}$ & $1 \mathrm{~s}$ & $\begin{array}{l}\text { Ryerson et al. (1998); Ry- } \\
\text { erson et al. (2000) }\end{array}$ \\
\hline Carbon dioxide $\left(\mathrm{CO}_{2}\right)$ & Nondispersive IR absorption & $\pm 0.13 \mathrm{ppmv}$ & $1 \mathrm{~s}$ & Peischl et al. (2010) \\
\hline Carbon monoxide (CO) & UV vacuum fluorescence & $3 \%$ & $1 \mathrm{~s}$ & Holloway et al. (2000) \\
\hline Long-lived trace gases ${ }^{\mathrm{b}}$ & $\begin{array}{l}\text { Glass flask sampler; GC and fluores- } \\
\text { cence analysis }\end{array}$ & varies & $\begin{array}{l}7-20 \mathrm{~s} \text { sample } \\
\text { time, } 12 \\
\text { flasks/flight }\end{array}$ & Montzka et al. (2004) \\
\hline Oxygenated VOCs & $\begin{array}{l}\text { Proton transfer reaction mass spectrom- } \\
\text { eter }\end{array}$ & varies & $\sim 15 \mathrm{~s}$ & $\begin{array}{l}\text { de Gouw et al. } \\
\text { (2003a); de Gouw and } \\
\text { Warneke (2007) }\end{array}$ \\
\hline $\mathrm{SO}_{2}$ & UV fluorescence & $13 \% \pm 0.55 \mathrm{ppbv}$ & $1 \mathrm{~s}$ & Ryerson et al. (1998) \\
\hline $\mathrm{SO}_{2}$ & $\mathrm{CIMS}^{\mathrm{c}}$ with $\mathrm{SF}_{6}^{-}$as reagent ion & $20 \% \pm 0.05 \mathrm{ppbv}$ & $3 \mathrm{~s}$ & Huey et al. (2004) \\
\hline $\mathrm{HNO}_{3}$ & CIMS with $\mathrm{SF}_{6}^{-}$as reagent ion & $25 \% \pm 0.15 \mathrm{ppbv}$ & $3 \mathrm{~s}$ & Huey et al. (2004) \\
\hline Peroxyacyl nitric anhydrides (PANs) & CIMS with $\mathrm{I}^{-}$as reagent ion & $20 \% \pm 20 \mathrm{pptv}$ & $\sim 5 \mathrm{~s}$ & Slusher et al. (2004) \\
\hline $\begin{array}{l}\mathrm{HOBr}+\mathrm{Br}_{2} \\
\mathrm{BrO}, \mathrm{BrCl}\end{array}$ & CIMS with $\mathrm{I}^{-}$as reagent ion & $\begin{array}{l}15 \%+2 \mathrm{pptv} \\
40 \%+3 \mathrm{pptv}\end{array}$ & $2 \mathrm{~s}$ & Neuman et al. (2010) \\
\hline
\end{tabular}

${ }^{a}$ Droplet Measurement Technologies, Inc., Boulder, Colorado, USA

b Analyzed for 21 halocarbons, 6 non-methane hydrocarbons, $\mathrm{CO}, \mathrm{CO}_{2}, \mathrm{H}_{2}, \mathrm{~N}_{2} \mathrm{O}, \mathrm{SF}_{6}, \mathrm{COS}, \mathrm{CS}_{2}$, and $\mathrm{CH}_{4}$.

${ }^{\mathrm{c}}$ Chemical ionization mass spectrometer

found in Warneke et al. (2009, 2010), Bierwirth et al. (2010), Fisher et al. (2010), Lance et al. (2010, 2011), Neuman et al. (2010), and Spackman et al. (2010), and will be pub- lished in other contributions. A summary of NASA's ARCTAS project (Jacob et al., 2010) has been published, as has an overview of the Arctic meteorology occurring during the 
time frame of the ARCTAS and ARCPAC projects (Fuelberg et al., 2010). Many papers related to the above programs and others associated with POLARCAT may be found in a special issue of Atmos. Chem. Phys. (http://www. atmos-chem-phys.net/special_issue $182 . \mathrm{html}$ ).

\section{Methods}

\subsection{Airborne instrumentation}

Fast-response, airborne measurements were made of trace gases, of aerosol compositional, microphysical, cloud nucleating and optical properties, of hydrometeor concentration, size, and shape, of atmospheric state parameters and winds, of ultraviolet, visible, and infrared radiation, and of location (Table 1). These measurements were made aboard a NOAA WP-3D aircraft, a four-engine turboprop airplane capable of flight durations in excess of 8 hours at true airspeeds of $\sim 100 \mathrm{~m} \mathrm{~s}^{-1}$ (http://www.aoc.noaa.gov/). Characteristics and sampling details for most of the instruments may be found in prior publications (Ryerson et al., 1998, 1999, 2000; Holloway et al., 2000; Brock et al., 2008). All but one cabinmounted aerosol instruments operated downstream of a low turbulence inlet (LTI, Wilson et al., 2004) and a multi-orifice impactor with greased substrate and a $1 \mu \mathrm{m}$ aerodynamic diameter $(\sim 0.7 \mu \mathrm{m}$ physical diameter) cut-point. Our analysis will focus on measurements made in the cabin with a compact time-of-flight aerosol mass spectrometer (AMS), a single particle soot photometer (SP2), a particle soot absorption photometer (PSAP), a cloud condensation nucleus (CCN) counter, an ultra high sensitivity aerosol spectrometer (UHSAS), a white light optical particle counter (WLOPC, which sampled upstream of the $1 \mu \mathrm{m}$ impactor) and an aerosol cavity ringdown spectrometer (CRDS). In addition to these instruments that operated downstream of the LTI, a fivechannel condensation particle counter (Brock et al., 2000) was mounted in an unpressurized underwing pod and sampled from a separate inlet with known particle transmission characteristics (Jonsson et al., 1995). A single-particle aerosol mass spectrometer (PALMS), also mounted in the pod, alternately sampled from either a forward facing aerosol inlet or a redesigned version of a counterflow virtual impactor (CVI) inlet (Cziczo et al., 2004). In addition to the aerosol observations, measurements of $\mathrm{CO}$, acetonitrile $\left(\mathrm{CH}_{3} \mathrm{CN}\right), \mathrm{O}_{3}, \mathrm{SO}_{2}$, and the halogen species $\mathrm{HOBr}+\mathrm{Br}_{2}$, $\mathrm{BrO}$, and $\mathrm{BrCl}$ are key to the analysis presented here.

Accuracy and precision for many of the instruments were determined by in-flight calibration and zeroing. Instrument comparisons were performed during separate coordinated flights with the NASA DC-8 and P-3B aircraft in which the NOAA WP-3D flew at the same altitude with a typical horizontal separation of $0.25( \pm 0.10) \mathrm{km}$. Results from this comparison (http://www-air.larc.nasa.gov/ TAbMEP2_polarcat.html) show that submicron particle com-

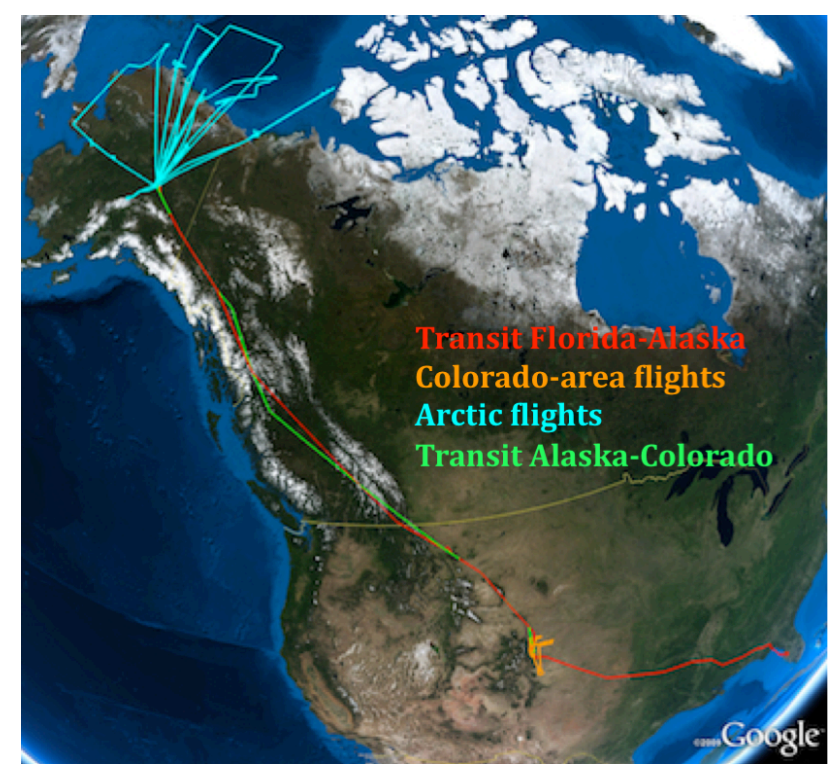

Fig. 1. Map of flight track for entire ARCPAC mission. Earth image courtesy NASA/JPL-Caltech.

position, number, surface area, and volume largely agreed within experimental uncertainties. In contrast, supermicron particle size distributions and quantities derived from those measurements compared poorly, with differences often exceeding the stated experimental uncertainties. These supermicron data are not central to this paper. All qualitycontrolled and processed airborne data from the ARCPAC project are available at http://www.esrl.noaa.gov/csd/ tropchem/2008ARCPAC/P3/DataDownload/.

Measurements were made during 10 flights, 4 of which involved transit to Alaska or measurements in the Denver, Colorado area (Fig. 1, Table 2). The aircraft was based in Fairbanks, Alaska from 3 to 23 April 2008. The 6 flights entirely within the Alaskan Arctic, from 11-21 April 2008 (in addition to arrival and departure profiles on 3 and 23 April, respectively), encompassed a region bounded by the western edge of Alaska near the Bering Strait to the Chukchi and Beaufort Seas northwest and northeast of Barrow, Alaska, respectively. Aircraft flight tracks (Fig. 2) included vertical profiles to altitudes as high as $7.4 \mathrm{~km}$, level flight legs sampling airmasses of interest, and transects at low altitude $(<500 \mathrm{~m})$ over the sea-ice surface, often within the surface inversion layer, with brief descents to $\sim 70 \mathrm{~m}$. The aircraft flight path was planned to sample specific regions based upon predictions by transport and coupled transportchemistry models, notably FLEXPART (http://transport.nilu. no/flexpart) and the Regional Air Quality Monitoring System (http://raqms-ops.ssec.wisc.edu/index.php). As a result, the statistics of aircraft sampling are biased toward forecast transport events. Furthermore, early and widespread 

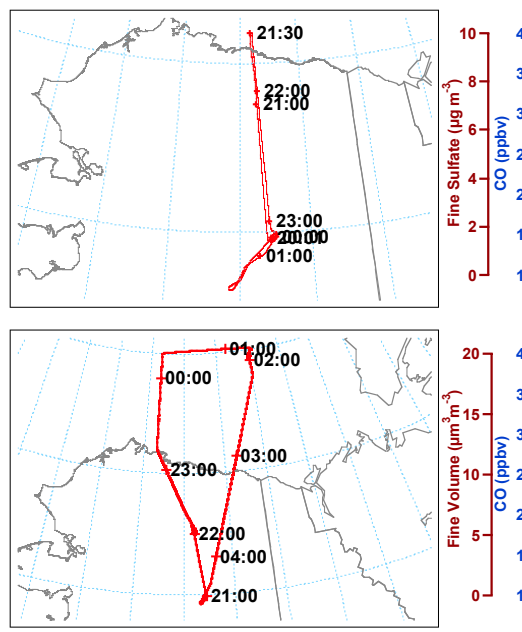

In situ measurements

FLEXPART simulation
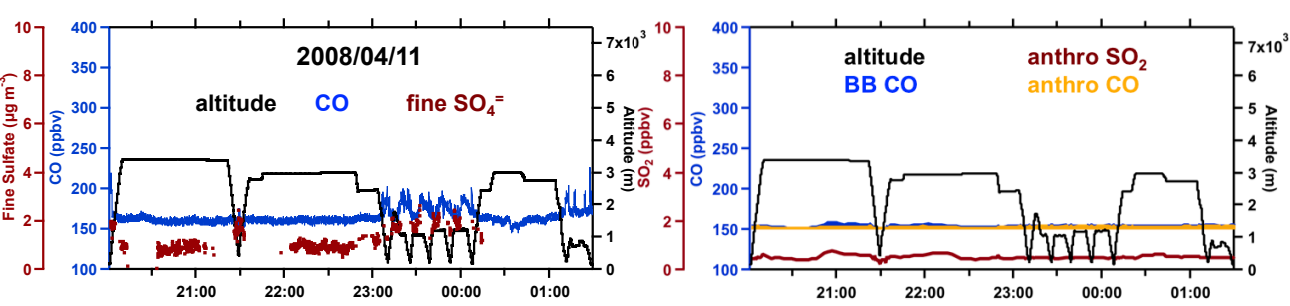
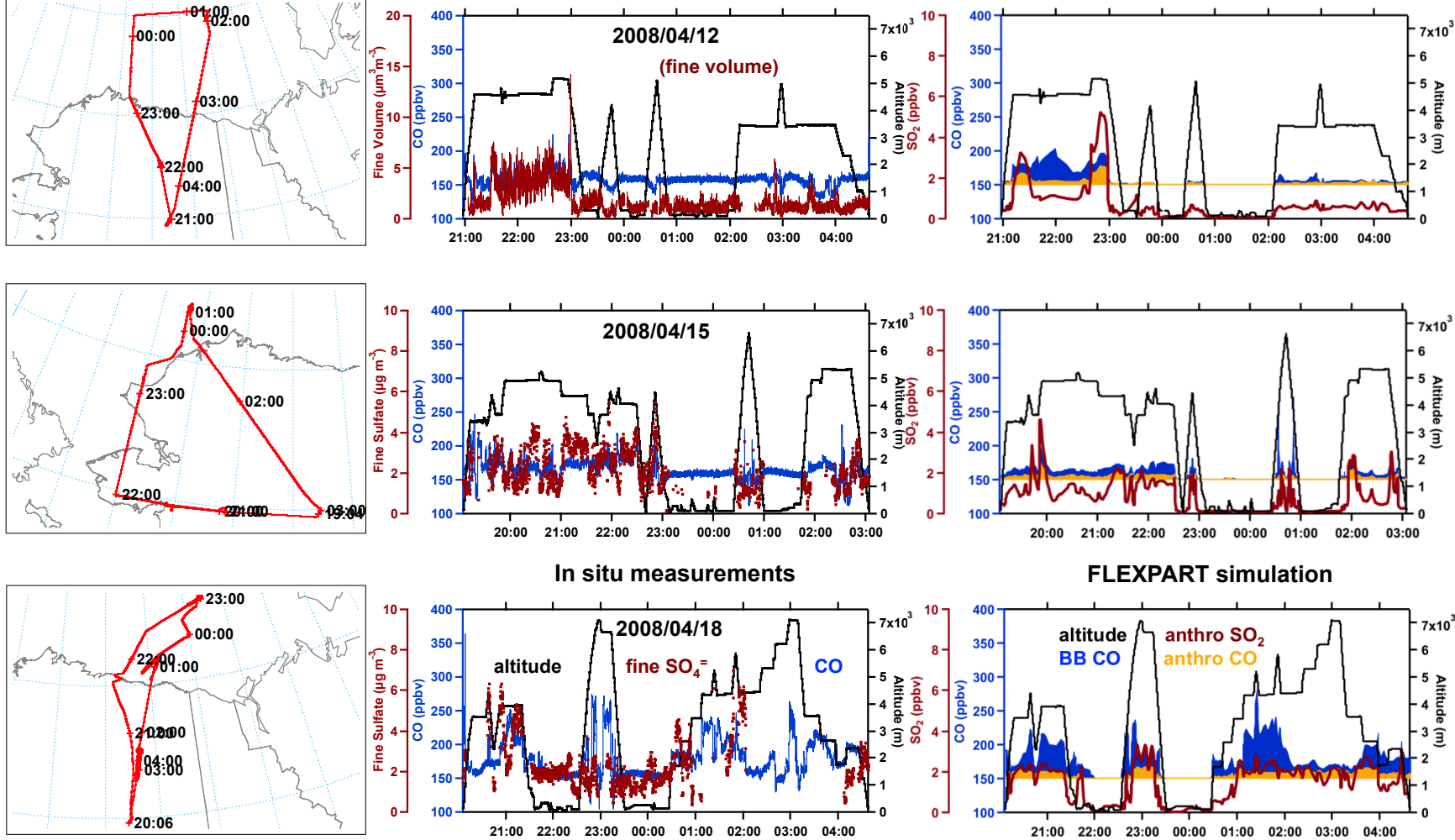

In situ measurements
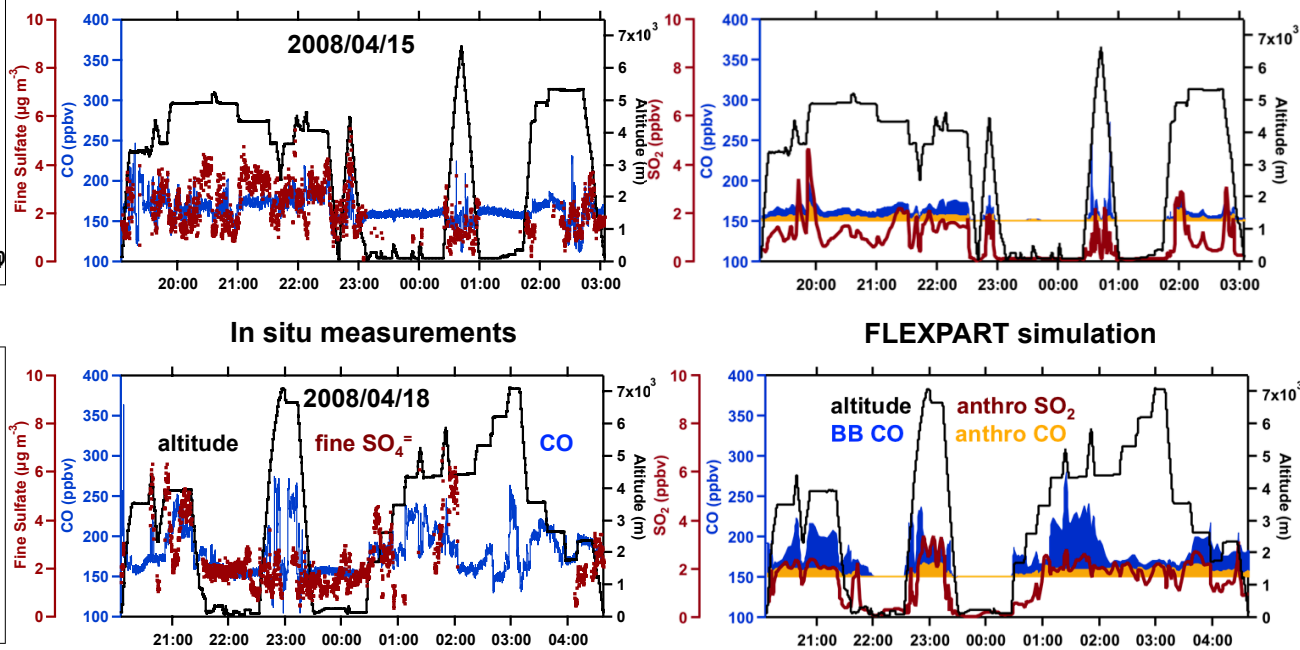

FLEXPART simulation
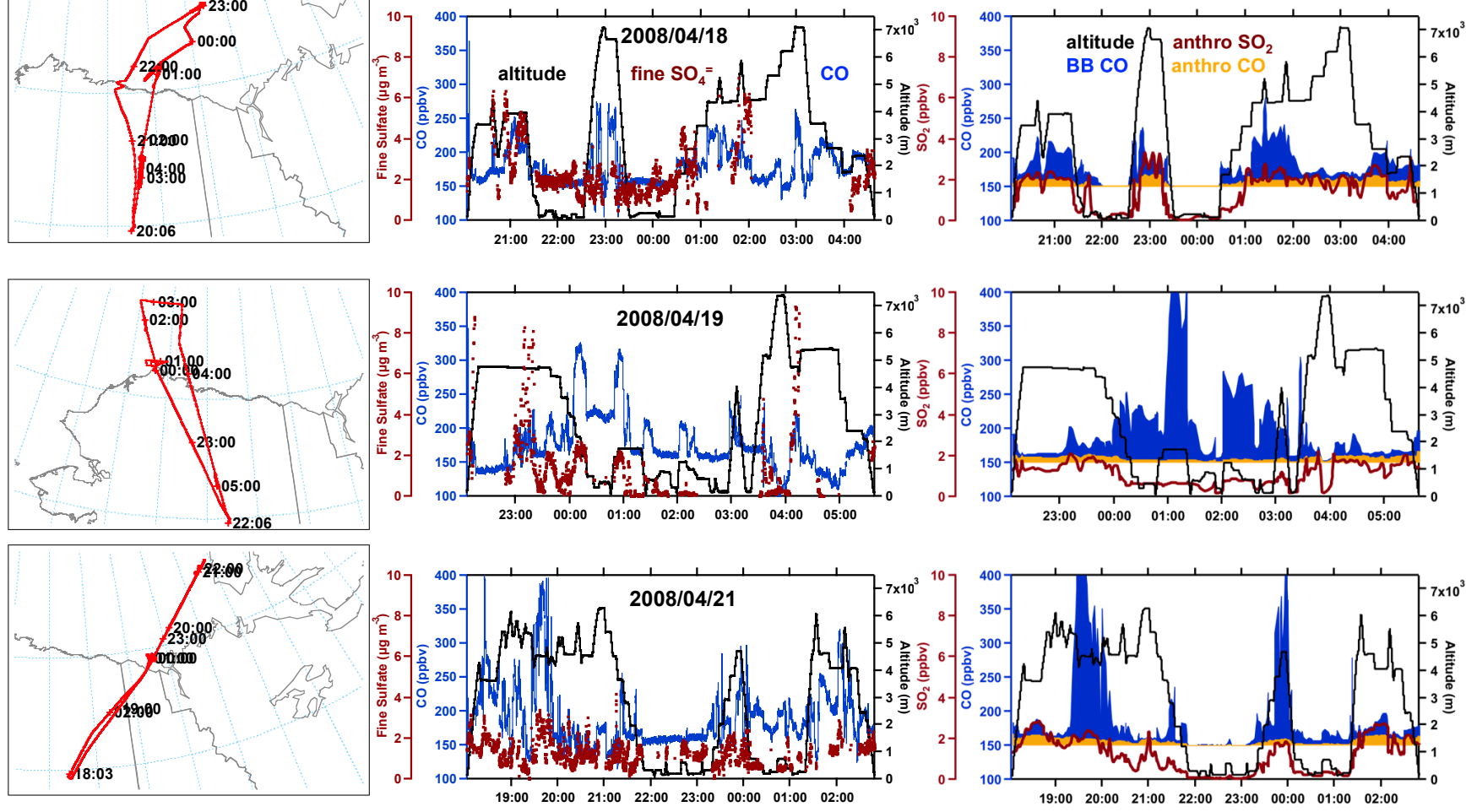

Fig. 2. Flight tracks (left column), in situ measurements (center column) and FLEXPART model simulations (right column) for all flights within Alaska during ARCPAC. Measured parameters are altitude, $\mathrm{CO}$, and fine $\mathrm{SO}_{4=}$. (on 12 April 2008, the AMS instrument did not function and fine particle volume is shown.) Modeled parameters are anthropogenic $\mathrm{SO}_{2}, \mathrm{CO}$ from $\mathrm{BB}$ sources and $\mathrm{CO}$ from anthropogenic sources, including emissions within only the last 20 days. A 150 ppbv offset is applied to $\mathrm{CO}$ values to represent background $\mathrm{CO}$, which includes aged $\mathrm{BB}$, anthropogenic, and biogenic components. 
Table 2. Flights times, locations, coordination with other platforms, and conditions encountered.

\begin{tabular}{|c|c|c|c|}
\hline Date & Location & Coordination & Conditions \\
\hline 29 Mar 2008 & Tampa, FL-Denver, CO & & $\begin{array}{l}\text { Boundary layer legs in polluted conditions; low } \\
\text { altitude leg and missed approach over Denver }\end{array}$ \\
\hline 1 Apr 2008 & Denver, CO-area flight & $\begin{array}{l}\text { Tall tower } \mathrm{CO}_{2} \text { sampling site } \\
\text { flyby }\end{array}$ & $\begin{array}{l}\text { Sampling of urban, agricultural, and industrial } \\
\text { emissions }\end{array}$ \\
\hline 3 Apr 2008 & $\begin{array}{l}\text { Denver, CO-Billings, } \\
\text { MT-Fairbanks, AK }\end{array}$ & & $\begin{array}{l}6-7 \mathrm{~km} \text { cruise altitude, descent and ascent to/from } \\
\text { Billings }\end{array}$ \\
\hline 11 Apr 2008 & $\begin{array}{l}\text { Fairbanks, AK N to coastline, } \\
\text { south to Alaska Range }\end{array}$ & & $\begin{array}{l}\text { Abbreviated flight; background haze; multiple } \\
\text { approaches to Fairbanks in modest local pollution }\end{array}$ \\
\hline 12 Apr 2008 & North Slope, Beaufort Sea & $\begin{array}{l}\text { Comparison with DC-8, } \\
\text { NASA B-200 HSRL overflight }\end{array}$ & $\begin{array}{l}\text { BB layers; background haze; Prudhoe bay plumes } \\
\text { ages } \sim 30 \text { and } \sim 40 \mathrm{~h} ; \mathrm{O}_{3} \text { depletion }\end{array}$ \\
\hline 15 Apr 2008 & $\begin{array}{l}\text { West-central Alaska, Bering } \\
\text { Strait, Chukchi Sea, North } \\
\text { Slope }\end{array}$ & $\begin{array}{l}\text { Comparison and radiative } \\
\text { closure stacked legs with } \\
\text { NASA P-3B, NASA B-200 } \\
\text { HSRL overflight }\end{array}$ & $\begin{array}{l}\text { BB layers; anthropogenic pollution layers; } \\
\text { background haze; } \mathrm{O}_{3} \text { depletion over sea-ice }\end{array}$ \\
\hline 18 Apr 2008 & $\begin{array}{l}\text { North Slope, Prudhoe Bay, } \\
\text { Beaufort Sea }\end{array}$ & & $\begin{array}{l}\text { BB layers; fresh Prudhoe Bay plume; aged Prudhoe } \\
\text { Bay plume; background haze; } \mathrm{O}_{3} \text { depletion }\end{array}$ \\
\hline 19 Apr 2008 & $\begin{array}{l}\text { North Slope, Barrow, } \\
\text { Chukchi and Beaufort } \\
\text { Seas }\end{array}$ & $\begin{array}{l}\text { Comparison with Canadian } \\
\text { NRC Convair } 580 \text { aircraft } \\
\text { with 5-min. separation, } \\
\text { NASA B-200 HSRL over- } \\
\text { flight, Barrow ground-based } \\
\text { observations }\end{array}$ & $\begin{array}{l}\text { Very dense BB plumes, some mixed with clouds, in } \\
\text { wave cyclone warm sector with strong midlatitude } \\
\text { advection; background haze in cold sector; } \\
\mathrm{O}_{3} \text { depletion; in-cloud measurements }\end{array}$ \\
\hline 21 Apr 2008 & $\begin{array}{l}\text { North Slope, Beaufort Sea, } \\
\text { Banks Island }\end{array}$ & & $\begin{array}{l}\text { BB layers; background haze; stacked legs on cold } \\
\text { and warm sides of front above, within, and below } \\
\text { clouds; } \mathrm{O}_{3} \text { depletion }\end{array}$ \\
\hline 23 Apr 2008 & Fairbanks, AK-Denver, CO & & $\begin{array}{l}\text { Dense BB smoke over Fairbanks; dust layer and BB } \\
\text { smoke at } 7 \mathrm{~km} \text { altitude over SE Alaska }\end{array}$ \\
\hline
\end{tabular}

seasonal BB in Russia occurred during the ARCPAC measurement period, strongly affecting aerosol properties and dominating observed transport events. Despite these biases, the NOAA WP-3D aircraft sampled airmasses containing diffuse anthropogenic Arctic haze, some denser aerosol layers with evident anthropogenic influences, and air within the sea-ice surface layer with distinctive gas-phase and aerosol characteristics.

\subsection{Transport models}

To assist the flight planning during the ARCPAC project, the FLEXPART model (Stohl et al., 2005) was used in forward mode to predict the spatial distribution of a few emission tracers in the study domain using meteorological forecast data. After the campaign, FLEXPART version 8.0 was used in backward mode to evaluate the sources and transport paths that contributed to concentrations of gas-phase compounds sampled by the WP-3D aircraft (http://zardoz.nilu. no/ andreas/ARCPAC/). Every time the aircraft changed horizontal location by 0.2 degrees of latitude or longitude, or when aircraft static pressure changed by more than $10 \mathrm{hPa}$, $6 \times 10^{4}$ parcel backtrajectories of 20-day duration were calculated from a grid box surrounding the location of the aircraft. The trajectories were calculated using the ECMWF gridded hemispheric meteorological fields with turbulence and convection parameterizations (Stohl et al., 2005). The FLEXPART emission sensitivity output for the lowest $100 \mathrm{~m}$ of the atmosphere was convolved with emission inventories to predict the distribution and mixing of specific trace species. For ARCPAC, the EDGAR anthropogenic emissions inventory (Olivier and Berdowski, 2001) was used outside of North America and Europe for $\mathrm{NO}_{2}, \mathrm{SO}_{2}$, and $\mathrm{CO}$, while the inventories of Frost et al. (2006) for North America and EMEP 2005 for Europe were used for these species. The inventory from Bond et al. (2004) was used to describe anthropogenic $\mathrm{BC}$ emissions. Emissions of $\mathrm{CO}$ and $\mathrm{BC}$ from BB were modeled as described by Stohl et al. (2007) using fire locations detected by the moderate-resolution imaging spectrometer (MODIS) on the Aqua and Terra satellites and a land-cover vegetation classification. Smoke was injected within the lowest $100 \mathrm{~m}$ above the surface; it quickly mixed vertically to fill the planetary boundary layer. No chemistry was incorporated into the model as used in this analysis; all emitted species were assumed to be passive tracers. The resulting model products included estimates of $\mathrm{CO}, \mathrm{BC}$, and total nitrogen and sulfur (as $\mathrm{NO}_{2}$ and $\mathrm{SO}_{2}$, respectively) at the location of the aircraft, the transport pathway of the air to the aircraft, and maps and numerical data regarding the predicted contribution of different anthropogenic and BB sources to the sampled air. Emission sources were tagged 
as anthropogenic or BB, and by region as European, North American, or Asian, or as originating from two specific fireprone regions in Russia.

Chemical and aerosol forecasts from RAQMS were also used for flight planning activities during ARCPAC. RAQMS is a unified (stratosphere/troposphere), online meteorological, chemical, and aerosol modeling system which has been developed for assimilating satellite observations of atmospheric chemical composition and providing real-time predictions of trace gas and aerosol distributions (Pierce et al., 2007). The RAQMS aerosol model incorporates online aerosol modules from GOCART (Chin et al., 2003). Six aerosol species $\left(\mathrm{SO}_{4}^{=}\right.$, hydrophobic organic carbon (OC), hydrophilic OC, BC, dust, and sea-salt) are transported. Biomass burning emissions in RAQMS are produced from twice daily ecosystem/severity based emission estimates coupled with MODIS Rapid Response fire detections (AlSaadi et al., 2008). Movies showing RAQMS-simulated sulfate, $\mathrm{OC}+\mathrm{BC}$, and dust transport are provided in the Supplement.

\section{Results}

The remainder of this manuscript contains a brief discussion of aerosol measurement consistency, and then focuses on observations made in four different regimes:

1. background haze - regions above the top of the surface boundary layer, over both land and sea-ice, to $7.2 \mathrm{~km}$ that did not contain layers of locally enhanced aerosol or gas-phase species directly transported within the last 20 days from identifiable sources. Mixing ratios of $\mathrm{CO}$ were $<170 \mathrm{ppbv}$ (see below for exact screening methods), and acetonitrile $\left(\mathrm{CH}_{3} \mathrm{CN}\right)$ was $<100$ pptv. Air with stratospheric influence was not removed from this category.

2. biomass burning (BB) plumes - regions containing elevated mixing ratios of $\mathrm{CO}$ and acetonitrile. Samples in this category had $\mathrm{CO}>170 \mathrm{ppbv}$ and acetonitrile $>100$ pptv. Often $\mathrm{CO}_{2}$, methanol, $\mathrm{NO}_{\mathrm{y}}$ (the sum of $\mathrm{NO}+\mathrm{NO}_{2}\left(=\mathrm{NO}_{\mathrm{x}}\right), \mathrm{HNO}_{3}$, acyl peroxynitrates (PANs), alkyl nitrates, and other reactive nitrogen species) were enhanced compared to surrounding air.

3. anthropogenic plumes - regions containing elevated mixing ratios of $\mathrm{CO}(>170 \mathrm{ppbv})$ while acetonitrile remained $<100$ pptv. Often $\mathrm{CO}_{2}, \mathrm{NO}_{\mathrm{y}}$, and/or $\mathrm{SO}_{2}$, were also enhanced. These cases were infrequently observed, and were adjacent to BB plumes.

4. Arctic boundary layer over sea-ice $(A B L)$ - regions within the Arctic surface inversion layer over seaice and containing $\mathrm{O}_{3}$ mixing ratios $<20 \mathrm{ppbv}$ and/or significant enhancements in photochemically active bromine. Air within this region is assumed to have been in chemical contact with the sea-ice surface (Neuman et al., 2010), which included open and thinly ice-covered leads. Data between the top of the inversion layer and the $\mathrm{ABL}$ as defined above are excluded.

Data were placed into these categories by screening according to aircraft position and the gas-phase conditions indicated above. However, if the aircraft was flying predominantly in one airmass type and briefly $(<10 \mathrm{~s})$ passed into a different airmass type, the airmass classification was not changed for the short interval. This strategy was used because of differing sampling intervals and response times for various measurements, and to allow sufficient dynamic range for regression analyses. Thus there are, for example, some brief periods of data included in the "BB" category when acetonitrile and $\mathrm{CO}$ mixing ratios were appropriate for the "background haze" category. In addition to the four airmass categories listed above, measurements were made in air influenced by local emissions from the city of Fairbanks, Alaska (population 100 000), from the oil extraction, handling, and transport facilities in the vicinity of Prudhoe Bay, Alaska, and from the exhaust of the WP-3D itself. These data, clearly identifiable by geographic location and enhanced concentrations of $\mathrm{NO}, \mathrm{NO}_{2}, \mathrm{CO}, \mathrm{CO}_{2}$, and/or aerosol number, have been excluded from the categories above. Periods when the aircraft was in cloud have also been excluded, due to potential aerosol sampling artifacts from droplet and ice crystal shattering.

A vertical profile of several gas-phase and aerosol parameters (Fig. 3) illustrates the separation of the data into three of the four categories, as well as the complex vertical structure. Layers of enhanced $\mathrm{CO}$, acetonitrile, organic aerosol mass, $\mathrm{BC}$, and aerosol optical extinction and absorption are evident, and are identified as being of BB origin. Note that the region from 3 to $3.5 \mathrm{~km}$ is identified as $\mathrm{BB}$, despite the lack of acetonitrile data (instrument zeroing), due to the similarity in other constituents with nearby BB layers. This figure illustrates the difficulty in separating observations into different classifications, and also emphasizes that the Arctic troposphere is composed of superimposed layers with differing characteristics, origins, and transport histories, rather than being a homogeneous airmass of static properties.

\subsection{Consistency among aerosol measurements}

Aerosol compositional, microphysical, and optical properties were measured by diverse techniques, including mass spectrometry, cavity ringdown spectrometry, light attenuation, incandescence, Kelvin diameter measurement, and light scattering amplitude (Table 1). In this analysis, we primarily use submicron particle composition measurements (from the AMS and SP2), single particle composition measurements from the PALMS, particle size distributions, aerosol light extinction from the CRDS, aerosol light absorption from the 

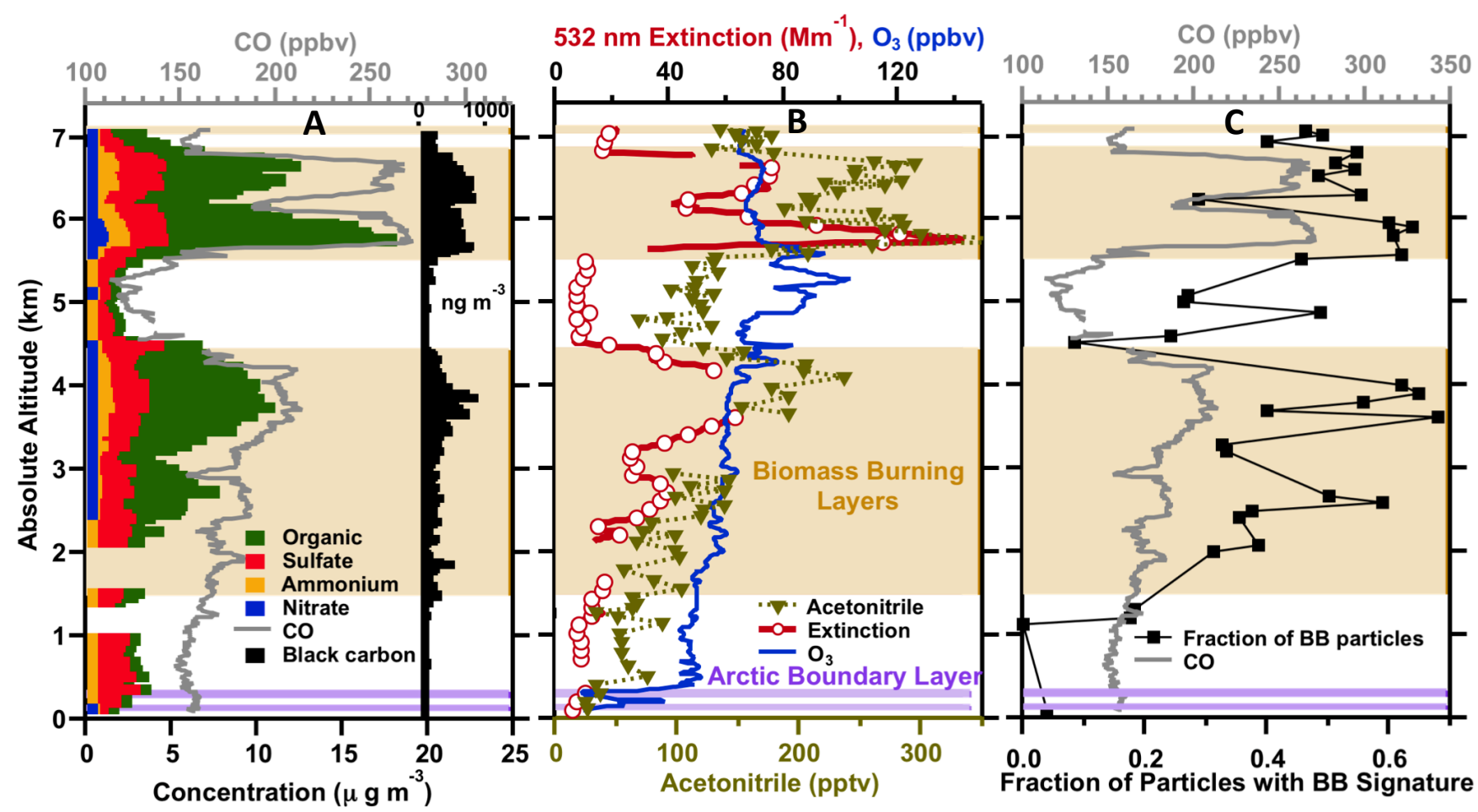

Fig. 3. Vertical profile measured during a slantwise ascent over sea-ice from 22:32-22:57 UTC on 18 April 2008 from $72.3^{\circ} \mathrm{N}, 143.2^{\circ} \mathrm{W}$ to $73.1^{\circ} \mathrm{N}, 137.7^{\circ} \mathrm{W}$. (A) submicron particle composition measured by the AMS, CO mixing ratio, and BC concentration. (B) aerosol extinction, $\mathrm{O}_{3}$, and acetonitrile mixing ratios. Tan and purple shading show regions identified as being directly influenced by BB, and being within the ABL, respectively. Regions with no shading are in the "background" category. (C) mixing ratio of CO and number fraction of particles with aerodynamic diameters $<0.7 \mu \mathrm{m}$ classified as containing a biomass/biofuel burning component by the PALMS instrument. Data gaps are instrument calibrations or zeros.

PSAP, and CCN concentrations. Here we assess the level of consistency among the different aerosol instruments that quantitatively measure the dry submicron aerosol.

The primary instrument measuring the accumulation mode aerosol size distribution, the UHSAS optical particle size spectrometer, had substantial pressure-dependent concentration biases caused by the sample flow control system (see Supplement). These biases were corrected, and uncertainty estimates (Table 1) account for potential errors caused by the correction.

The dry particle volume calculated from the measured size distributions agrees within stated uncertainty with volume calculated from the particle composition measurements (Table 1), assuming densities of $1.30 \times 10^{3}, 1.75 \times 10^{3}$, and $1.80 \times 10^{3} \mathrm{~kg} \mathrm{~m}^{-3}$ for the organic (Turpin and Lim, 2001), inorganic, and BC (Bond and Bergstrom, 2006) constituents, respectively (Fig. 4). Although the measurements are highly correlated $\left(r^{2}>0.91\right)$ and agree within stated uncertainties, there is a systematic bias of up to $25 \%$ in which the volume derived from the compositional measurements (primarily the AMS) is less than that derived from the size measurements for all the analyzed data. This apparent bias changes signs, with AMS higher than size distribution measurements by $8 \%$ when considering only those data with a molar ratio, $F_{\mathrm{mr}}$, of ammonium to the sum of the inorganic anionic species $<1.5$ (Fig. 4), or when the organic mass fraction is $<0.7$ (not shown). This composition-dependent variation suggests biases introduced by particle phase-dependent AMS collection efficiency (Matthew et al., 2008), for which the correction applied in data processing may not be accurate. Part of the discrepancy may also be due to lens transmission of the AMS, since 5 to $8 \%$ of the mass resides in particles large enough to be sampled with $<100 \%$ transmission efficiency. Refractive index variations, which would affect particle sizing from the UHSAS (Cai et al., 2008), could also contribute to the evident bias, especially since volume is calculated from the 3 rd moment of particle diameter. Since the refractive index of organic compounds is poorly constrained (Kanakidou et al., 2005; Dick et al., 2007), a constant refractive index of 1.52-0i, appropriate for the ammonium sulfate particles used for calibration (Toon et al., 1976) and near the center of the estimated range for oxidized organic matter, was used to relate scattered light intensity to particle size. A final cause of the bias may be due to refractory material (sea-salt and dust) that is measured by the UHSAS but not volatilized in the aerosol impactor/heater in 


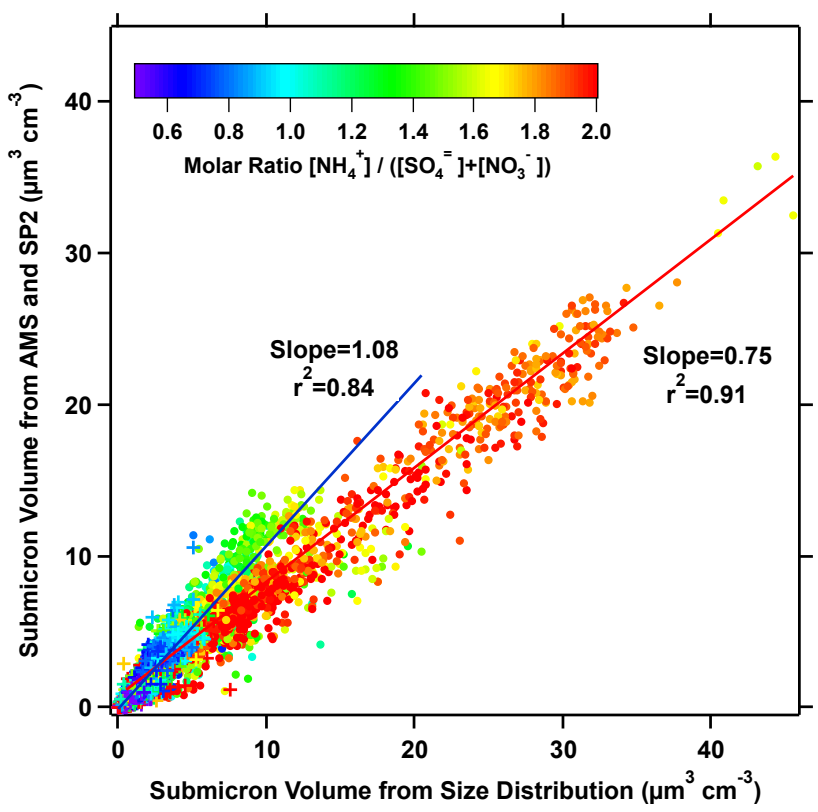

Fig. 4. Submicron dry particle volume determined from AMS and SP2 speciated mass measurements. Dots were acquired in BB plumes; crosses were acquired in anthropogenic plumes and background and sea-ice boundary layer conditions. Symbols colorcoded by the measured molar ratio of $\mathrm{NH}_{4}^{+} /\left(\mathrm{SO}_{4}^{=}+\mathrm{NO}_{3}^{-}\right), F_{\mathrm{mr}}$. Lines are fits to data with $F_{\mathrm{mr}} \geq 1.5$ (red line) and $<1.5$ (blue line).

the AMS. However, dust is a minor contributor to the sub$0.5 \mu \mathrm{m}$ aerosol mass, while sea-salt is likely to be significant only near the Arctic surface, where it can comprise $20 \%$ of the submicron mass (Quinn et al., 2002).

The integrated light scattering at a wavelength of $532 \mathrm{~nm}$,

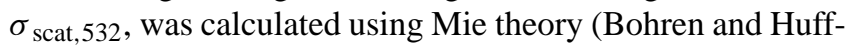
man, 1983) from the measured dry size distributions, assuming a refractive index of 1.52-0i. The calculated scattering was compared with that derived from the extinction

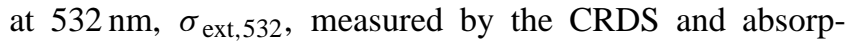
tion at $530 \mathrm{~nm}, \sigma_{\mathrm{abs}, 530}$, measured by the PSAP. The scattering derived from these two approaches was highly correlated $\left(r^{2}=0.98\right)$ and the slope was within stated experimental uncertainty (Fig. 5). However, a bias of $26 \%$ is evident, with the more directly measured extinction-absorption value higher than that calculated by Mie theory from the size distributions. The scattering calculated from the size distributions is subject to minor errors due to the assumed refractive index, to the uncertainty in the size of the calibration particles, and to the assumption of homogeneous, spherical scattering. A larger contributor to the observed bias is likely concentration uncertainties exacerbated by the pressure-dependent flow issues described in the Supplement. In contrast, the extinction measurement, which dominates scattering, is calibrated by gas-phase absorption and is subject to smaller uncertainties (Baynard et al., 2007).

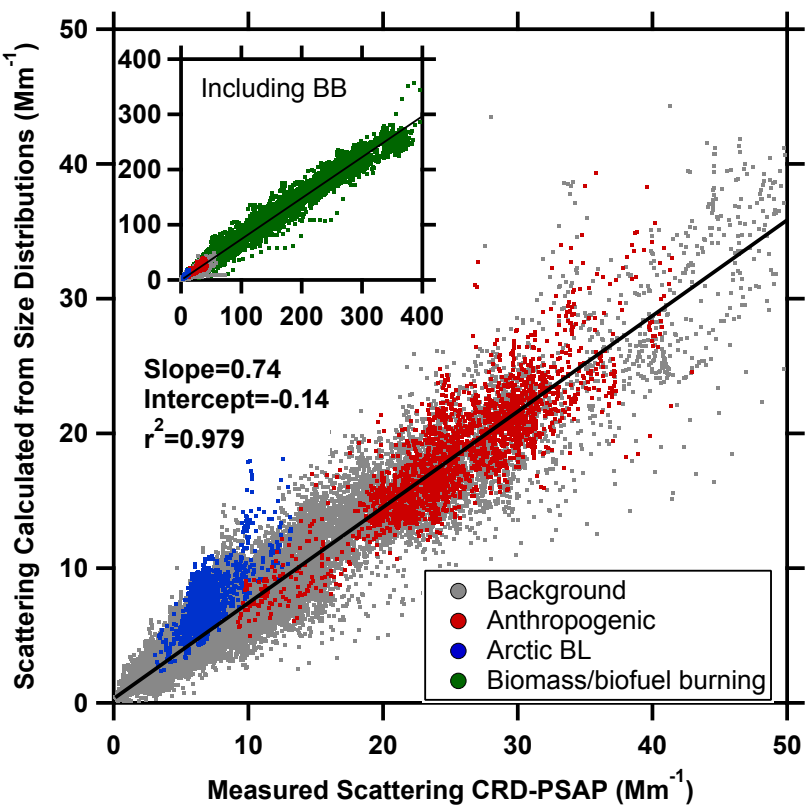

Fig. 5. Aerosol scattering coefficient calculated from measured particle size distributions as a function of scattering calculated from direct extinction and absorption measurements. Line is a linear leastsquares regression to all data.

In summary, the extinction data are higher than the size distribution data, which in turn are higher than the AMS data. While the AMS, size distribution, and optical measurements are consistent within stated uncertainties, remaining biases are substantial and should be considered when interpreting the data.

\subsection{Background arctic haze}

The free troposphere over northern Alaska and adjacent waters was strongly influenced by anthropogenic and biomass emissions, even in the absence of discrete plumes from identifiable sources. This influence was most obvious in the mixing ratio of $\mathrm{CO}$, which in winter is produced primarily from combustion (Fisher et al., 2010). Mean CO mixing ratios were $160 \pm 3$ ppbv (Fig. 6c, Table 3). This relatively high $\mathrm{CO}$ mixing ratio is characteristic of the polluted northern hemisphere in early spring and is caused by a decrease in the photochemical loss of $\mathrm{CO}$ in the winter months as well as a seasonal increase in anthropogenic and biomass/biofuel emissions, especially in Europe and northern Asia (e.g., Novelli et al., 1992, 1998; Pétron et al., 2002; Fisher et al., 2010; Kopacz et al., 2010).

\subsubsection{Aerosol composition and microphysical properties}

The concentrations of submicron aerosol constituents in background haze conditions were also enhanced relative to remote, unpolluted areas in the springtime midlatitude 
Table 3. Values of trace gas and aerosol parameters in different airmass types ${ }^{\mathrm{a}}$.

\begin{tabular}{|c|c|c|c|c|}
\hline Parameter & $\begin{array}{c}\text { Sea-ice } \\
\text { boundary layer }\end{array}$ & $\begin{array}{l}\text { Free tropospheric } \\
\text { background haze }\end{array}$ & $\begin{array}{l}\text { Anthropogenic } \\
\text { plumes }\end{array}$ & BB plumes \\
\hline $\mathrm{CO}$ (ppbv) & $160 \pm 3$ & $161 \pm 8$ & $174 \pm 6$ & $190_{\div}^{\times} 1.21^{\mathrm{b}}$ \\
\hline Acetonitrile (pptv) & $48 \pm 20$ & $77 \pm 46$ & $107^{\times} 1.58$ & $172 \div 1.97$ \\
\hline $\mathrm{O}_{3}(\mathrm{ppbv})$ & $10 \div 2.39$ & $52 \pm 14$ & $56 \pm 1$ & $69 \pm 14$ \\
\hline NO (ppbv) & $-0.002 \pm 0.01$ & $-0.001 \pm 0.01$ & $0.000 \pm 0.01$ & $0.007 \pm .01$ \\
\hline $\mathrm{NO}_{2}$ (ppbv) & $0.008 \pm 0.03$ & $0.012 \pm 0.04$ & $0.016 \pm 0.03$ & $0.037 \pm 0.04$ \\
\hline $\mathrm{HNO}_{3}(\mathrm{ppbv})$ & $0.01 \pm 0.08$ & $0.03 \pm 0.1$ & $0.01 \pm 0.05$ & $0.09 \pm 0.2$ \\
\hline $\mathrm{NO}_{\mathrm{y}}(\mathrm{ppbv})$ & $0.32 \pm 0.4$ & $0.40 \pm 0.17$ & $0.54 \pm 0.18$ & $0.91 \pm 0.47$ \\
\hline $\mathrm{SO}_{2}$ (ppbv) & $0.01 \pm 0.3$ & $0.05 \pm 0.5$ & $0.16 \pm 0.6$ & $0.16 \pm 0.5$ \\
\hline Submicron number $\left(\mathrm{cm}^{-3} \mathrm{STP}\right)$ & $178_{\div}^{\times} 1.30$ & $371_{\div}^{\times} 1.84$ & $627 \stackrel{\times}{\div} 1.24$ & $910_{\div}^{\times} 1.90$ \\
\hline Submicron volume $\left(\mu \mathrm{m} \mathrm{cm}^{-3} \mathrm{STP}\right)$ & $1.1 \div 1.42$ & $1.2^{\times} 2.01$ & $3.2^{\times} \div 1.38$ & $5.6 \div 2.27$ \\
\hline $\begin{array}{l}\text { Supermicron volume } \\
\left(\mu \mathrm{m} \mathrm{cm}{ }^{-3} \mathrm{STP}\right)\end{array}$ & $1.0_{\div}^{\times} 2.07$ & $0.7^{\times} 2.19$ & $1.2^{\times} \div 1.33$ & $1.7^{\times} \div 2.59$ \\
\hline Number geometric mean diameter $(\mu \mathrm{m})$ & $0.178 \pm 0.01$ & $0.167 \pm 0.02$ & $0.174 \pm 0.01$ & $0.189 \div 1.19$ \\
\hline \multirow[t]{2}{*}{ Geometric standard deviation } & $1.52^{\times} \div 1.05$ & mode $1: 1.54 \stackrel{\times}{\times} 1.15$ & $1.54 \stackrel{\times}{\div} 1.08$ & $1.50 \div \frac{\times}{\div} 1.05$ \\
\hline & & mode $2: 1.19 \stackrel{\times}{\times} 1.03$ & & \\
\hline Extinction at $532 \mathrm{~nm}\left(\mathrm{Mm}^{-1}\right.$ at STP $)$ & $6.3_{\div}^{\times} 1.41$ & $8.9^{\times} 1.82$ & $27 \stackrel{\times}{\div} 1.33$ & $55_{\div}^{\times} 2.47$ \\
\hline Absorption at $532 \mathrm{~nm}\left(\mathrm{Mm}^{-1}\right.$ at STP $)$ & $0.15^{\times} \div 2.11$ & $0.40 \div 2.23$ & $1.2^{\times} 1.46$ & $2.2^{\times} \div 2.89$ \\
\hline Single scattering albedo & $0.974 \pm 0.019$ & $0.959 \pm 0.019$ & $0.957 \pm 0.011$ & $0.967 \pm 0.022$ \\
\hline$\gamma$ extinction & $0.97\left(\begin{array}{cc}1.06 & \\
0.55\end{array}\right) c$ & $0.63\left(\begin{array}{cc}0.83 & \\
& 0.49\end{array}\right)$ & $1.09\left(\begin{array}{cc}1.17 & \\
& 0.96\end{array}\right)$ & $0.45\left(\begin{array}{cc}0.68 & \\
& 0.34\end{array}\right)$ \\
\hline Angstrom exponent of extinction $1064 / 532$ & $1.73 \div 2.10$ & $2.04 \times 1.57$ & $2.65_{\div}^{\times} 1.19$ & $2.26_{\div}^{\times} 1.13$ \\
\hline Asymmetry parameter & $0.62 \pm 0.05$ & $0.58 \pm 0.06$ & $0.60 \pm 0.03$ & $0.62 \pm 0.04$ \\
\hline $\begin{array}{l}\text { Fraction of particles active as } \mathrm{CCN} \text { at SS: } \\
0.10 \pm 0.04 \%\end{array}$ & $0.54 \pm 0.11$ & $0.36 \pm 0.12$ & $0.41 \pm 0.07$ & $0.40 \pm 0.09$ \\
\hline 0.15 to $0.42 \%$ & $0.88 \pm 0.15$ & $0.88 \pm 0.15$ & $0.87 \pm 0.11$ & $0.88 \pm 0.11$ \\
\hline $\mathrm{BC}\left(\mathrm{ng} \mathrm{m}^{-3} \mathrm{STP}\right)$ & $18 \div 3.20$ & $60 \div 3.74$ & $148_{\div}^{\times} 2.26$ & $312 \div 2.73$ \\
\hline AMS organic $\left(\mu \mathrm{g} \mathrm{m}^{-3} \mathrm{STP}\right)$ & $0.27^{\times} 1.99$ & $0.71_{\div}^{\times} 3.15$ & $2.0_{\div}^{\times} 1.68$ & $5.4_{\div}^{\times} 2.57$ \\
\hline AMS sulfate $\left(\mu \mathrm{g} \mathrm{m}^{-3} \mathrm{STP}\right)$ & $1.2^{\times} \div 1.33$ & $1.1_{\div}^{\times} 2.01$ & $3.5^{\times} \div 1.18$ & $1.9^{\times} 2.22$ \\
\hline AMS nitrate $\left(\mu \mathrm{g} \mathrm{m}^{-3} \mathrm{STP}\right)$ & $0.012\left(\begin{array}{c}0.022 \\
0.006\end{array}\right)$ & $0.03 \times 5.80$ & $0.06 \div 2.42$ & $0.36_{\div}^{\times} 5.27$ \\
\hline AMS ammonium $\left(\mu \mathrm{g} \mathrm{m}^{-3} \mathrm{STP}\right)$ & $0.15_{\div}^{\times} 1.85$ & $0.21_{\div}^{\times} 2.73$ & $0.55_{\div}^{\times} 1.23$ & $0.84 \div 2.18$ \\
\hline AMS total $\left(\mu \mathrm{g} \mathrm{m}^{-3} \mathrm{STP}\right)$ & $1.6_{\div}^{\times} 1.40$ & $2.1_{\div}^{\times} 2.44$ & $6.1_{\div}^{\times} 1.16$ & $9.0_{\div}^{\times} 2.30$ \\
\hline
\end{tabular}

${ }^{a}$ From least-square Gaussian (normal) fits to probability distribution function (PDF) for each parameter and airmass type.

${ }^{\mathrm{b}} \mathrm{A} \stackrel{\times}{\div}$ symbol indicates that the probability density function and associated fit for this measurement is lognormal.

${ }^{\mathrm{c}}$ Median values and interquartile range shown (data were distributed neither normally nor lognormally).

${ }^{\mathrm{d}}$ Fit to histogram of instantaneous (10-s) sum of AMS total non-refractory aerosol mass. May not equal sum of the individual component means calculated as in a 

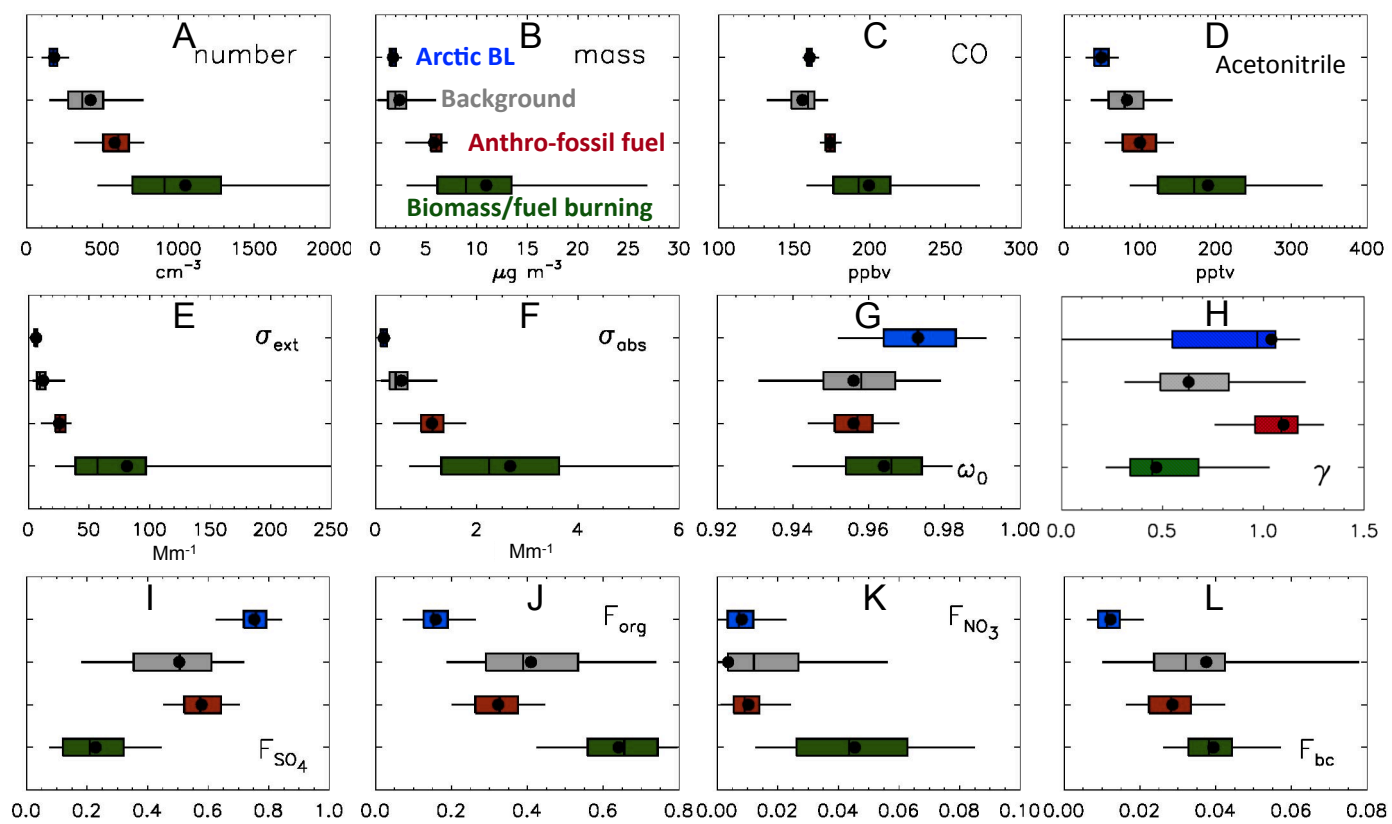

Fig. 6. Statistics of occurrence for parameters separated by airmass classification. Each box encloses the interquartile range and the whiskers the 5th and 95th percentiles. The vertical bar and symbol are the median and arithmetic mean, respectively. ((A) submicron aerosol number concentration, (B) submicron non-refractory aerosol mass concentration, (C) CO mixing ratio, (D) acetonitrile mixing (AN) ratio, (E) fine aerosol extinction at $532 \mathrm{~nm}\left(\sigma_{\text {ext }}\right),(\mathbf{F})$ fine aerosol absorption at $530 \mathrm{~nm}\left(\sigma_{\text {abs }}\right)$, (G) fine aerosol single scattering albedo $\omega_{o}$, H) hygroscopicity parameter $\gamma$ (Eq. 1), (I) fraction of fine mass that is $\mathrm{SO}_{4}^{=}\left(\mathrm{F}_{\mathrm{SO}}\right)$, ( $\left.\mathbf{J}\right)$ fraction of fine mass that is organic $\left(\mathrm{F}_{\mathrm{org}}\right)$, $(\mathbf{K})$ fraction of fine mass that is $\mathrm{NO}_{3}^{-}\left(\mathrm{F}_{\mathrm{NO}}\right)$, and $(\mathbf{L})$ fraction of fine mass that is $\mathrm{BC}\left(\mathrm{F}_{\mathrm{BC}}\right)$. All extensive aerosol parameters, including $\sigma_{\text {ext }}$ and $\sigma_{\text {abs }}$, are at STP $(1013 \mathrm{hPa}, 273.15 \mathrm{~K})$ conditions at a measurement RH of $<10 \%$. Additional statistical summaries for these and other parameters are in Table 3.

free troposphere (e.g., Brock et al., 2004; Peltier et al., 2008; Dunlea et al., 2009). Histograms of concentrations of extensive aerosol parameters were lognormally distributed. For all lognormally distributed data we use geometric means and standard deviations to describe their statistics of occurrence; otherwise Gaussian statistics are applied (Table 3). We also use medians and quartiles to graphically summarize several parameters (Fig. 6). Geometric mean aerosol sulfate concentrations in background haze were $1.1 \stackrel{\times}{\leftarrow} 2.01) \mu \mathrm{g} \mathrm{m}^{-3}$, and organic concentrations were highly variable at $0.71(\stackrel{\times}{\div} 3.15) \mu \mathrm{g} \mathrm{m}^{-3}$ (values with $\stackrel{\times}{\div}$ are geometric standard deviations). Nitrate and ammonium were $\sim 1 \%$ and $\sim 10 \%$, respectively, of the non-refractory submicron aerosol mass, and nitrate was often below the detection limit of $0.02 \mu \mathrm{g} \mathrm{m}^{-3}$ for $10-\mathrm{s}$ measurements. The mean ionic ratio of ammonium to the sum of measured anions was 0.6 , indicating that the inorganic constituents of the aerosol were only partially neutralized. Black carbon was $\sim 3 \%$ of the total submicron mass.

Particle size distributions in these polluted background conditions were varied, attesting to the diverse sources and ages of the layers found within this airmass classification. Typical size distributions included an accumulation mode with a number geometric mean diameter, $D_{g, n}$, of $\sim 0.17 \mu \mathrm{m}$.
A mode of coarse particles was present between 1 and $5 \mu \mathrm{m}$ in the volume distribution (Fig. 7). The total volume within this mode was $\sim 60 \%$ of that found in the accumulation mode (Table 3). An Aitken mode contributing 10\% or more of the total particle number was present $58 \%$ of the time in the background haze; this mode had a variable $D_{g, n}$ ranging from 0.008 to $0.05 \mu \mathrm{m}$. Mean particle number and mass concentrations were $371 \mathrm{~cm}^{-3}$ and $2.1 \mu \mathrm{g} \mathrm{m}{ }^{-3}$, respectively (Fig. 6a, b; Table 3), with a composition that was $35 \%$ organic with sulfate comprising the large majority of the remaining mass (Fig. 6i, j, k, Fig. 7, Table 3). At a supersaturation (SS) of $0.10( \pm 0.04) \%, 36( \pm 12) \%$ of the particles were active CCN. This fraction of CCN increased to $88( \pm 15) \%$ for SS between 0.15 and $0.42 \%$.

Particles with diameters in two size classes (fine, 0.15 to $0.7 \mu \mathrm{m}$ and coarse, 0.7 to $3 \mu \mathrm{m}$ ) were placed into one of six compositional categories based upon the positive or negative mass spectrum from individual particles as measured by the PALMS instrument (Froyd et al., 2009). The categories include particles with a biomass/biofuel component (Hudson et al. 2004), sulfate/organic internal mixtures with no biomass material, elemental carbon, mineral dust, sea-salt, and unclassified. Note that the particles are classified according to their dominant spectral characteristics; 


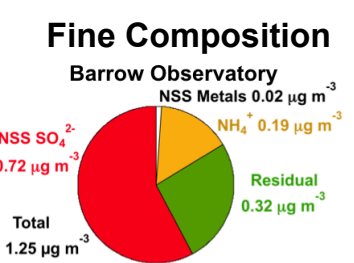

\section{Single Particle Number Fraction Ion Balance

Fine Coarse \\ Particle Size Distribution}

Arctic Boundary Layer
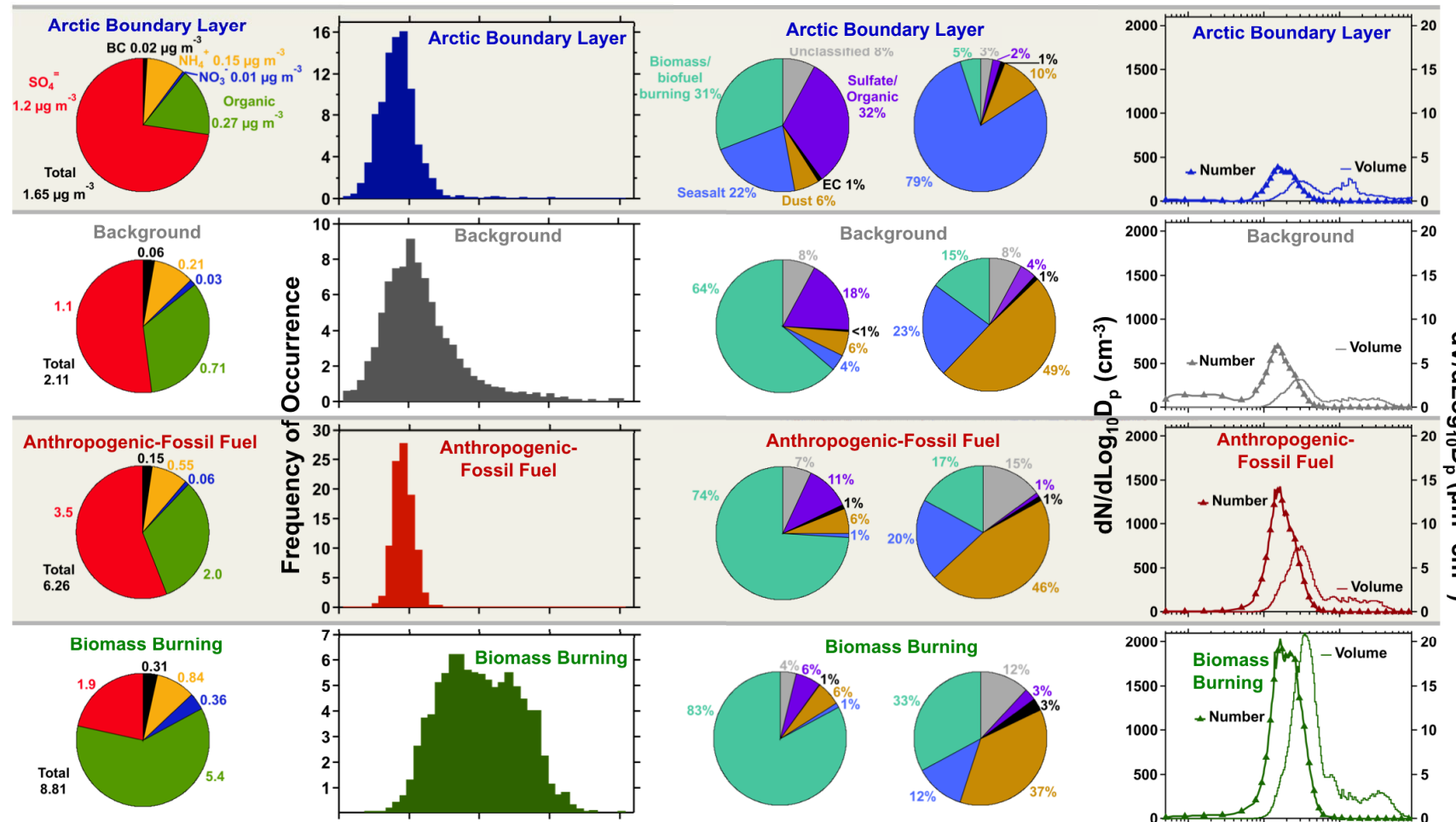

Background
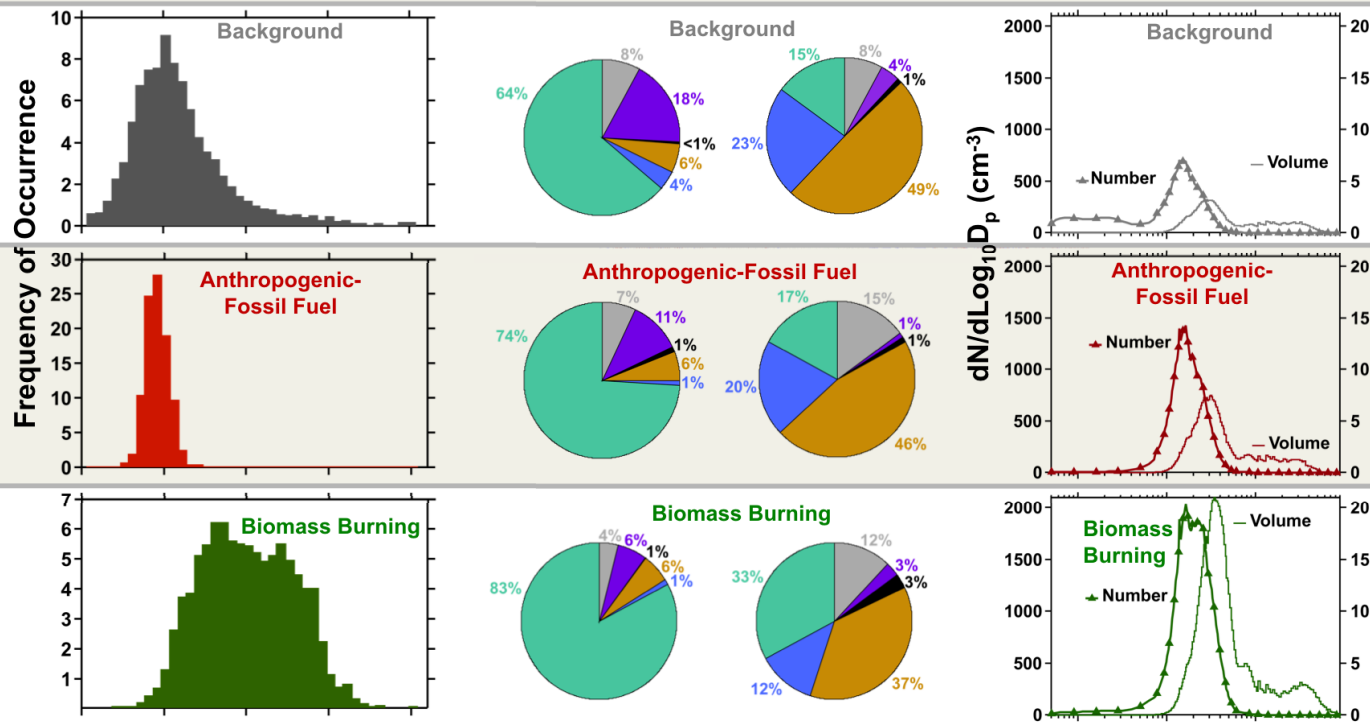
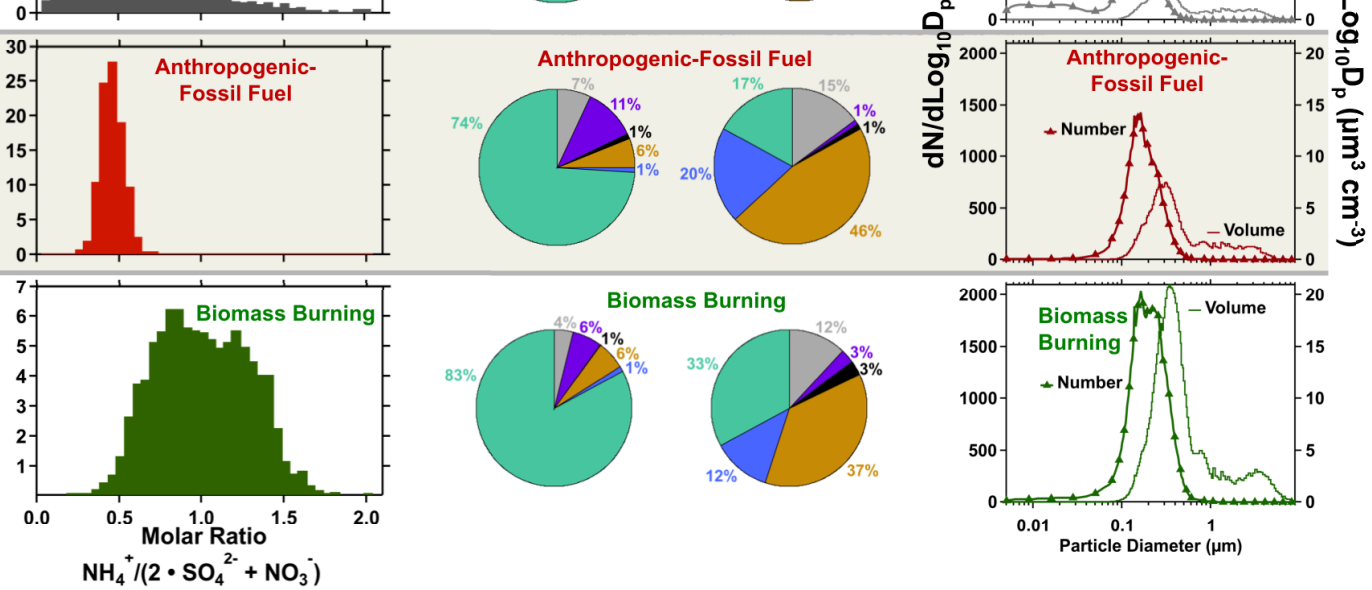

Fig. 7. Average composition and size distributions apportioned into the 4 airmass categories. Left column: bulk composition for submicron particles $(\mathrm{OA}=$ organic aerosol; $\mathrm{BC}=$ black carbon). First pie chart contains submicron particle mass from 1997-2000 from the NOAA Observatory at Barrow, Alaska (Quinn et al., 2002); NSS = non sea-salt; residual = unspeciated mass (probably organic); sea-salt components not shown. Second column: approximate charge balance from major ions as determined by the AMS. Third and fourth columns: number fraction of particles with diameters from $0.15-0.7 \mu \mathrm{m}$ and $0.7-3 \mu \mathrm{m}$, respectively, placed into 6 compositional categories based on single particle mass spectra measured by the PALMS instrument $(\mathrm{EC}=$ elemental carbon). Right column: particle number (symbols, left axis) and volume (line, right axis) size distributions.

many particles are likely to be a mixture of types, yet are placed in the category with the most dominant spectral signature. Within the "background" category, $64 \%$ of fine particles had a biomass/biofuel compositional signature, while particles with sulfate/organic signatures comprised $18 \%$ of the fine particle number (Fig. 7). In contrast, in the coarse mode, $49 \%$ of the particles were mineral dust, followed in number contribution by sea-salt, particles with a biomass/biofuel signature, unclassified particles and particles with sulfate/organic signatures. In both the fine and coarse mode, elemental carbon particles contributed $1 \%$ or less of the particle number.
The reader's attention may be drawn to the difference in particle composition as reported by the AMS and the PALMS instruments (Fig. 7). Due to transmission losses within its aerodynamic lens, the AMS did not efficiently sample particles with physical diameters $>0.5 \mu \mathrm{m}$ (Bahreini et al., 2008). Furthermore, the AMS composition is mass-based while the PALMS apportionment is based on number frequency of occurrence. The PALMS categorization is based on the presence of marker species, and does not necessarily represent the only important contributor to that particle's mass. Thus the fact that the AMS shows that $52 \%$ of the nonrefractory fine particle mass measured in the Arctic background aerosol was composed of sulfate does not contradict 
the PALMS measurements showing that only $18 \%$ by number of the fine mode particles were classified as predominantly sulfate/organic internal mixtures, since particles classified as BB by the PALMS can also contain substantial nonrefractory sulfate material (Hudson et al., 2004).

\subsubsection{Aerosol optical properties}

In the polluted background airmass, dry aerosol extinction at $532 \mathrm{~nm}$ was $<10 \mathrm{Mm}^{-1}$ and the aerosol was highly scattering, with a single scattering albedo of $\sim 0.96$. The asymmetry parameter (the cosine-weighted integral of the scattering phase function, used in radiative transfer calculations) was $\sim 0.6$ at $532 \mathrm{~nm}$, similar to values of $\sim 0.58$ for $550 \mathrm{~nm}$ reported for the springtime submicron aerosol at the surface at Barrow, Alaska (Fiebig and Ogren, 2006). The term $\gamma$, which is a key parameter in understanding the variation in light extinction due to changing atmospheric relative humidity, $f(\mathrm{RH})$, was determined from continuously operating, parallel, humidified extinction measurements and is defined such that (Doherty et al., 2005)

$f(\mathrm{RH})=\frac{\sigma_{\mathrm{ext}, 532, \mathrm{RH}}}{\sigma_{\mathrm{ext}, 532, \mathrm{RH}_{0}}}=\left(\frac{100-\mathrm{RH}_{0}}{100-\mathrm{RH}}\right)^{\gamma}$,

where $\mathrm{RH}_{o}$ and $\mathrm{RH}$ are the dry $(<10 \%)$ and humidified $(\sim 60 \%$ and $\sim 85 \%)$ instrumental relative humidity conditions, respectively. The value of $\gamma$ was determined by fitting the extinction data at the three measurement humidities. For the background haze category, the geometric mean value of $\gamma$ at $532 \mathrm{~nm}$ was 0.63 (Fig. 6h, Table 3).

\subsubsection{Origins and transport}

Simulations of the origins of the background aerosol are difficult because of the long time scales of transport involved. FLEXPART simulations during background conditions do not show substantial direct transport from known sources. Analysis with an Eulerian atmospheric transport and chemistry model shows an increase in $\mathrm{CO}$ during the winter and spring months due to transport of anthropogenic emissions from Europe, northwestern Asia, and China (Fisher et al., 2010). The observed background concentrations of $\mathrm{CO}$ are consistent with this model of enhanced emission and transport, and reduced wintertime photochemical loss. The aerosol composition and size distribution measurements are also consistent with an aged, predominantly fossil fuelderived aerosol with a significant contribution from biomass and/or biofuel burning sources.

\subsection{Biomass burning plumes}

\subsubsection{Aerosol composition and microphysical properties}

The striking feature dominating the measurements made aboard the NOAA WP-3D aircraft from 12 to 23 April,
2008 was the unexpected, frequent occurrence of layers of enhanced aerosol and gas-phase species that were attributable to BB (Warneke et al., 2009, 2010). These layers were identified by enhancements in $\mathrm{CO}$ from background values of $\sim 160 \mathrm{ppbv}$ to a 95th-percentile value of 273 ppbv (Fig. 6c) and a maximum value of 419 ppbv, and by correlated enhancements in acetonitrile, a specific tracer of biomass/biofuel combustion (de Gouw et al., 2003b). Singleparticle compositional measurements (Fig. 7) showed that on average $83 \%$ of the 0.15 to $0.7 \mu \mathrm{m}$ diameter particles in these plumes had a substantial biomass/biofuel signature (Hudson et al., 2004). Geometric mean fine aerosol mass concentrations were $9.0 \mu \mathrm{g} \mathrm{m}^{-3}$ with a geometric standard deviation of 2.30 and a 95 th percentile value of $27 \mu \mathrm{g} \mathrm{m}^{-3}$. Aerosol composition within the BB plumes was dominated by organic compounds which comprised $60 \%$ of the non-refractory submicron mass. Sulfate was present within the BB layers at a higher concentration than in the background haze (Fig. 7, Table 3). While agricultural and wild fires are not thought to be large sources of sulfur compounds (Hegg et al., 1987; Andreae and Merlet, 2001), the presence of enhanced particulate sulfate concentrations in these plumes, in the absence of obvious fossil fuel combustion sources co-located or immediately upwind of the fires, may call that assumption into question. Nitrate $\left(\mathrm{NO}_{3}^{-}\right)$and ammonium $\left(\mathrm{NH}_{4}^{+}\right)$were significantly higher within the BB plumes compared with the background haze, probably originating from fire emissions of $\mathrm{NO}_{\mathrm{x}}$ and $\mathrm{NH}_{3}$, respectively (e.g., Andreae and Merlet, 2001). Black carbon concentrations were enhanced within the BB plumes, but generally increased proportionally to the total aerosol mass concentrations. The $\mathrm{BC}$ mass fraction of the quantified submicron aerosol composition was $3.8 \pm 1.1 \%$ for the BB plumes, similar to the background $\mathrm{BC}$ fraction.

Submicron particles were present as a single mode with $D_{g, n}=0.19 \mu \mathrm{m}$ and a geometric standard deviation $\sigma_{g}=1.5$ (Fig. 7, Table 3). These mean values are consistent with those from various sources summarized in Table 6 and Fig. 11 of Petzold et al. (2007) for BB smoke transported for $\sim 6$ days, and with those recommended by Dentener et al. (2006) for biomass burning aerosol parameters for use in global system models. However, in ARCPAC, the BB plume particles were present in a single accumulation mode (Fig. 7), while Petzold et al. reported the presence of an attenuated Aitken mode $\left(D_{g, n}<0.10 \mu \mathrm{m}\right)$ in BB smoke transported from Alaska and western Canada over periods $>10$ days to $\mathrm{Eu}-$ rope. Furthermore, in ARCPAC values of $D_{g, n}$ varied systematically with $\mathrm{CO}$ within the BB plumes (Fig. 8) in a manner not described in these earlier studies. This relationship between $D_{g, n}$ and CO may have occurred because mixing of concentrated BB smoke with background air resulted in partitioning of semivolatile organic matter from the condensed to the gas phase (e.g., Donahue et al., 2009), thereby decreasing particle size in diluted BB smoke.

Submicron particle concentrations within the BB mode varied from 470 to $2000 \mathrm{~cm}^{-3}$ (5th and 95th percentiles), 
with a geometric mean of $910 \mathrm{~cm}^{-3}$. Submicron volume concentration ranged from 2.4 to $25 \mu \mathrm{m}^{3} \mathrm{~cm}^{-3}$ (5th and 95th percentiles) with a geometric mean of $5.6 \mu \mathrm{m}^{3} \mathrm{~cm}^{-3}$. Submicron particle surface area ranged from 56 to 464 $\mu \mathrm{m}^{2} \mathrm{~cm}^{-3}$ (5th and 95th percentiles) with a geometric mean of $122 \mu \mathrm{m}^{2} \mathrm{~cm}^{-3}$. Coarse particle geometric mean volume was $1.7 \mu \mathrm{m}^{3} \mathrm{~cm}^{-3}$, with a mass median diameter of $\sim 4 \mu \mathrm{m}$. At a supersaturation (SS) of $0.10( \pm 0.04) \%, 40( \pm 9) \%$ of the particles were active CCN. The fraction of activated $\mathrm{CCN}$ increased to $88( \pm 11) \%$ for SS between 0.15 and $0.42 \%$ (Table 3).

\subsubsection{Aerosol optical properties}

Submicron single scattering albedos at $532 \mathrm{~nm}$ were similar between the background Arctic haze and the BB plume cases, with 5th and 95th percentile values for the BB of 0.94 and 0.98 , respectively, and a median value of 0.97 (Fig. 6g). The calculated asymmetry parameter (the cosine-weighted integral of the scattering phase function) was not highly variable, with 5th and 95th percentile values of 0.57 and 0.66 , respectively, and a median value of 0.62 . The aerosol was moderately hygroscopic, with a geometric mean value of $\gamma$ of 0.45 . These values of $\gamma$ are comparable to the higher end of those in oxidized airmasses measured downwind of Asia, India, and North America for similar levels of organic mass fraction (Quinn et al., 2005), and suggest the organic matter was oxidized and not hydrophobic. This finding is consistent with analysis of AMS organic spectra (Zhang et al., 2005 ), which shows that $>90 \%$ of the organic mass in the BB plumes was highly oxygenated (not shown), and with the large fraction of particles active as CCN. In sum the BB particles were organic rich (yet still contained enhanced sulfate) were aged, highly scattering, significantly hygroscopic, and effective as CCN.

\subsubsection{Origins and transport}

The FLEXPART model often simulated the transport of $\mathrm{CO}$ from BB sources with remarkable spatial fidelity and with modeled mixing ratio enhancements generally within a factor of two of the measurements (Fig. 2). The model did not predict the occurrence of some plumes, particularly above $4 \mathrm{~km}$ altitude; these misses may be at least partly attributable to altitude displacement rather than gross errors in transport. The RAQMS model effectively simulated the general location of the transport of $\mathrm{CO}$ and aerosol particles from BB sources to the Arctic, although the Eulerian RAQMS model tended to overpredict $\mathrm{CO}$ mixing ratios and underpredict $\mathrm{OC}+\mathrm{BC}$ concentrations.

Two primary sources of smoke were identified based upon the FLEXPART and RAQMS simulations, which incorporate real-time emissions estimates from fires identified by MODIS satellite sensor imagery (Fig. 9). The first of these smoke sources was a broad region located along the Rus-

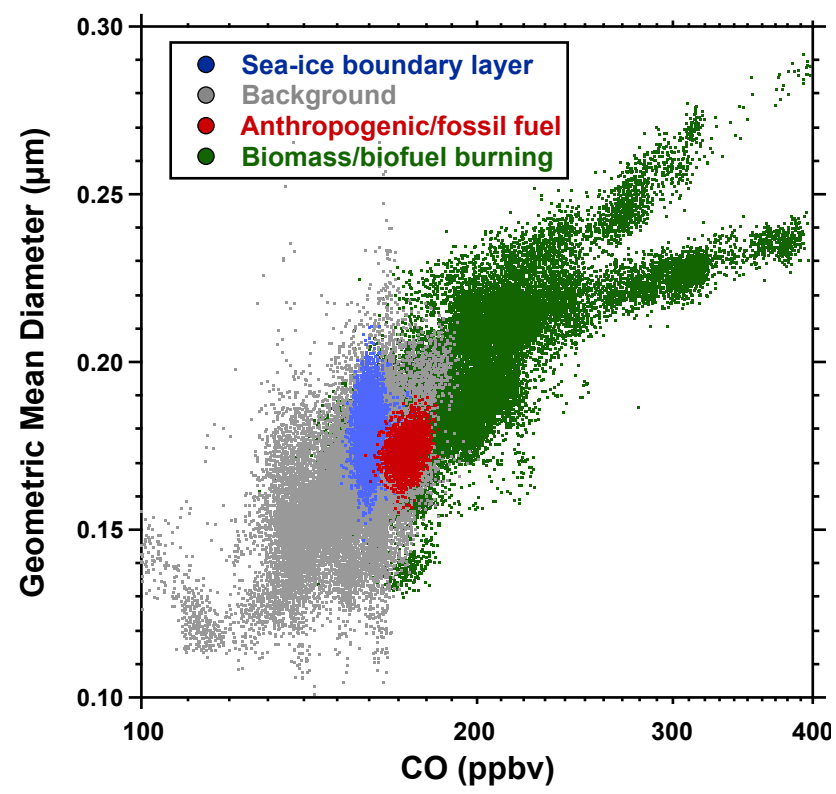

Fig. 8. Number geometric mean diameter as a function of CO mixing ratio calculated for particles with diameters from $0.08-1 \mu \mathrm{m}$ in four different airmass categories.

sia/Kazakhstan border, but predominantly on the Russian side. The vegetation in this area is a mix of agricultural lands, steppe grasslands and forest. Fires in this region probably originated with agricultural burning; some of these became wildfires. Fires in this region in springtime are an annual occurrence (Warneke et al., 2010). A second region of BB originated in southeastern Siberia, between Lake Baikal and the Pacific Ocean in the vicinity of the Chita and Amur Rivers. The vegetation in this region is a mix of grassland, shrubland, and coniferous forest. Images from the MODIS satellite sensors (NASA/University of Maryland, 2002) suggest that most of the fires occurred on forested land. Although there are no substantial vegetation differences across the Russia/China border, there were very strong gradients in BB occurrence (Fig. 9; Warneke et al., 2010). This suggests that fire ignition and/or control strategies differed across the political border. MODIS images indicate that much of the land in this region was snow-covered in late March; fires began soon after the snow at lower altitudes melted, suggesting deliberate ignition of moist fuels. MODIS images show merged plumes covering a broad region downwind of the many small fires.

Smoke from the two regions, henceforth referred to as southern Russia and southeastern Siberia, respectively, was episodically generated and transported to the Arctic based on the fire occurrence and meteorologically driven transport events. Figure 10 shows the FLEXPART-simulated emission and transport of these plumes over a 24-day period (movies of these images and of FLEXPART simulated BB transport superimposed on satellite cloud images are available in the 


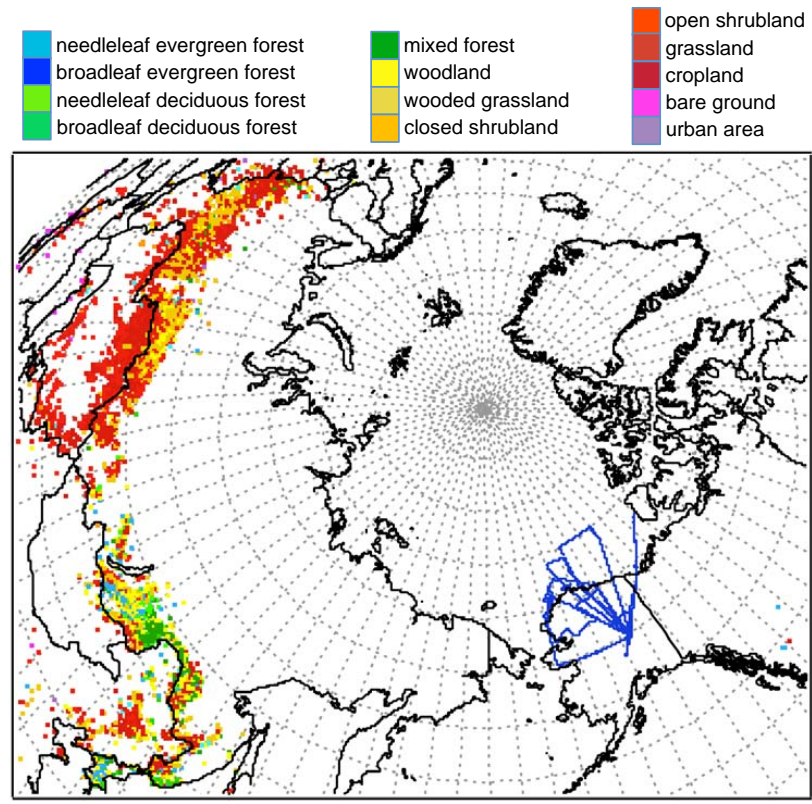

Fig. 9. Map showing fire locations for April 2008 determined from MODIS (NASA/University of Maryland, 2002), color-coded by the underlying vegetation type (Hansen et al., 2000).

online Supplement). Fires began east of Lake Baikal near the end of March and became widespread in mid-April. Transport from the midlatitudes to the Arctic occurred in 2 primary pulses (6 to 12 April and 16 to 25 April), each associated with midlatitude cyclones that advected smoke cyclonically upward and northward (Stohl et al., 2003). Within the Arctic, some of the smoke was sheared horizontally into filaments as it exited the cyclonic systems into the upstream anticyclones. Some of this sheared smoke became entrained into Arctic cyclonic and anticyclonic systems, although the majority of emitted smoke remained in high midlatitudes. By late April smoke had penetrated deeply into the Arctic, reaching the North Pole and extensively covering the panArctic region (Fig. 10; Saha et al., 2010). The primary consequences of such smoke layers on the Arctic environment are likely to be caused by direct and indirect radiative forcing and by in-cloud scavenging and wet deposition to the surface during transport. More long-term influences may result if the smoke does not rapidly exit the Arctic and is mixed to the ABL, in which case dry deposition to the surface may occur. These issues are discussed in Sect. 4.

\subsection{Anthropogenic/fossil fuel plumes}

Plumes that were predominantly from fossil fuel sources were classified as "anthropogenic/fossil fuel". These plumes, which were observed during only $\sim 1 \mathrm{~h}$ of total flight time on 15 April 2008, were identified by $\mathrm{CO}$ mixing ratios $>170 \mathrm{ppbv}$ in the absence of corresponding increases in acetonitrile. Furthermore, $\mathrm{SO}_{2}$ from the CIMS instrument was significantly elevated in these regions (mean mixing ratio 50 pptv) and was positively correlated with aerosol sulfate.

\subsubsection{Aerosol composition and microphysical properties}

The submicron aerosol composition in the anthropogenic/fossil fuel airmasses was dominated by sulfate, ammonium, and organics. Organic matter comprised only $33 \%$ of the non-refractory mass (Fig. 7, Table 3), in contrast to the organic-rich $\mathrm{BB}$ plumes $(\sim 65 \%$ organic mass fraction). The geometric mean sulfate concentration was $3.5 \mu \mathrm{g} \mathrm{m}^{-3}$. The mean ion balance between ammonium and measured anionic species was $\sim 0.5$, indicating that the sulfate was not fully neutralized (Fig. 7). The geometric mean concentration of $\mathrm{BC}$ was $148 \mathrm{ng} \mathrm{m}^{-3}$. The fractions of particles in each composition category were similar to those in background air. Both the number and volume size distributions were dominated by the accumulation mode, with a number geometric mean diameter of $0.17 \mu \mathrm{m}$ and a number concentration of $627 \mathrm{~cm}^{-3}$. Despite the higher sulfate concentrations and the $\mathrm{SO}_{2}$ that was present, there were no modes of smaller particles that would suggest recent new particle formation. At a supersaturation (SS) of $0.10( \pm 0.04) \%, 41( \pm 07) \%$ of the particles were active $\mathrm{CCN}$. The fraction of activated CCN increased to $87( \pm 11)$ $\%$ for SS between 0.15 and $0.42 \%$. The CCN activation fractions at either SS do not differ significantly from those for the background haze and biomass/biofuel burning cases.

\subsubsection{Aerosol optical properties}

Median values of extinction and absorption at $532 \mathrm{~nm}$ and submicron mass in the fossil fuel plumes were all approximately $1 / 2$ of the mean values for the BB plumes (Fig. 6b,e,f; Table 3$)$. The anthropogenic aerosol was significantly more hygroscopic $(\gamma=1.09)$ than was the BB aerosol $(\gamma=0.59)$. This degree of hygroscopicity in the anthropogenic plumes is higher than values reported in several aged fossil fuel influenced airmasses by Quinn et al. (2005) and Massoli et al. (2009) for similar organic mass fractions. The single scattering albedo in the anthropogenic layers was $0.96 \pm 0.01$, which was not significantly different from the BB value of $0.97 \pm 0.02$. In sum, the aerosol was dominated by acidic sulfate, and was monomodal, hygroscopic, and highly scattering.

\subsubsection{Origins and transport}

FLEXPART and RAQMS simulations indicate that the primary source of sulfur species within the anthropogenic layers encountered on 15 April 2008 was eastern China, with some contribution from eastern Europe. The sulfur-rich plumes were near other plumes dominated by $\mathrm{BB}$ emissions. The sulfur species likely originated from anthropogenic sources as indicated by the models, and were transported by the same midlatitude synoptic low pressure system that carried the BB 

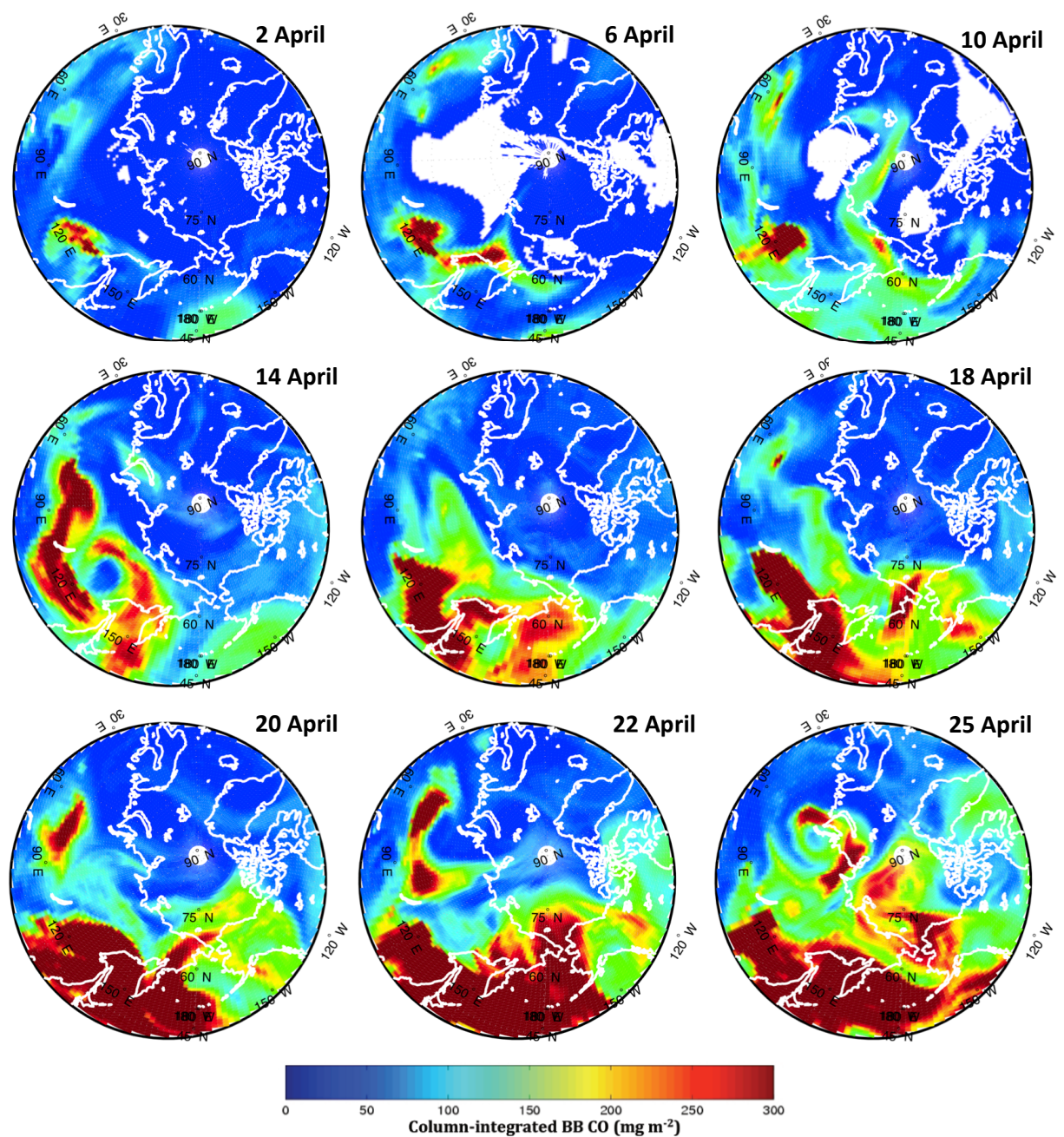

Fig. 10. Flexpart transport model simulations of a 20-day conserved CO tracer emitted by BB sources. These perturbations lie on top of a large CO background from other sources, primarily anthropogenic, of $\sim 900 \mathrm{mg} \mathrm{m}^{-2}$ (not shown).

plumes. Similar long-range transport of different types of pollution in adjacent layers without substantial mixing has been observed before (Clarke et al., 2001; Brock et al., 2004, 2008) and shows that laminar transport of sheared filaments and layers from different sources over intercontinental distances is common.

\subsection{Arctic Sea-Ice Boundary Layer (ABL)}

In winter and spring, a persistent surface inversion of variable depth and strength occurs over the Arctic Ocean (e.g. Vowinckel, 1970; Tjernström and Graversen, 2009). The air within this inversion is at or very near ice saturation (Andreas et al., 2002). Diffuse low-level clouds and clear-air "diamond dust" precipitation are common (Ohtake et al., 1982) because of heat and moisture fluxes from open and thinly ice-covered leads. Static stability is high, and wind-generated mechanical turbulence very near the surface and sporadic convective turbulence from newly exposed open-water leads are the primary mechanisms for vertical transport (Andreas and Murphy, 1986; Strunin et al., 1997; Pavelsky et al., 2010). The air within this layer is isolated from the air aloft due to the high static stability and may have a different source and transport history (Stohl, 2006).

The WP-3D aircraft penetrated the sea-ice inversion layer on 16 occasions, briefly descending to altitudes of $\sim 70 \mathrm{~m}$. An infrared sea-surface temperature (SST) sensor reported that open and thinly ice-covered leads (indicated by brief increases in SST $3 \mathrm{~K}$ or more above the local mean SST) were present directly below the aircraft $\sim 10 \%$ of the time while in the ABL. Although the top of the inversion layer was often above $1 \mathrm{~km}$ altitude, the moist ABL in which there was evidence of halogen chemistry was generally confined to altitudes $<800 \mathrm{~m}$. Several extended flight legs $\sim 200 \mathrm{~m}$ above the surface were made (Fig. 2). In situ data were classified 
into the ABL category based on the meteorological and gasphase chemical criteria described previously. A total of $5 \mathrm{~h}$ of flight time were spent within this airmass type.

\subsubsection{Aerosol composition and microphysical properties}

Within the moist ABL, the aerosol extensive properties, including mass concentration, extinction, absorption, and chemical species concentrations, were comparable to or less than values in the polluted background of the free troposphere (Fig. 6a-f; Table 3). Notably, BC and organic mass concentrations were lower than in the background airmass, while sulfate concentrations were similar or higher (Fig. 7).

The ABL submicron aerosol size distribution was similar to that of the background free troposphere (Fig. 7), although number concentrations were lower within the ABL (Fig. 6a). The coarse mode volume concentration was significantly lower in the ABL compared with the background air (Fig. 7, Table 3). Single particle composition information from the PALMS mass spectrometer instrument shows a distinct change in particle characteristics between the ABL and the free troposphere (Fig. 7). In the ABL, the coarse particle mode was composed mostly (79\%) of sea-salt particles. Coarse particles with dust and BB characteristics were infrequent in the inversion layer over sea-ice. About $22 \%$ of fine particles with diameters from 0.15 to $0.7 \mu \mathrm{m}$ were composed of sea-salt; this is consistent with the findings that seasalt contributes to $\sim 20 \%$ of fine aerosol mass measured at Barrow, Alaska (Quinn et al., 2002). The fraction of fine particles with a BB signature (31\%) was significantly lower than in the other airmass types, and was comparable to typical midlatitude tropospheric background values (Hudson et al., 2004). At a supersaturation (SS) of $0.10( \pm 0.04) \%$, $54( \pm 11) \%$ of the submicron particles were active $\mathrm{CCN}$, a higher activated fraction than was found in the other airmass categories (Table 3). The activated $\mathrm{CCN}$ fraction increased to $88( \pm 15) \%$ for SS between 0.15 and $0.42 \%$.

\subsubsection{Aerosol optical properties}

Submicron aerosol extinction and absorption at $532 \mathrm{~nm}$ were lower in the ABL than in the background free troposphere, consistent with the decrease in particle mass and $\mathrm{BC}$, respectively. As expected for the low $\mathrm{BC}$ fraction in the ABL, the single scattering albedo in the ABL was higher, 0.97, than the background case, 0.96 (Fig. 6g, Table 3). The $\mathrm{ABL}$ aerosol was more hygroscopic at $532 \mathrm{~nm}(\gamma=0.97)$ than were the background or BB cases, and was similar to the anthropogenic/fossil fuel case, in which the composition was also dominated by acidic sulfate. In sum, compared to the free tropospheric Arctic background haze, the ABL aerosol was reduced in quantity, enhanced in sulfate, deficient in organic matter and $\mathrm{BC}$, more hygroscopic, and more highly scattering.

\subsubsection{Origins and transport}

Despite some statistical similarities in gas-phase properties between the background and ABL airmasses, during individual vertical profiles there were often discrete changes in submicron aerosol characteristics as the aircraft penetrated the top of the ABL. In particular, particle number concentration, extinction, absorption, and $\mathrm{BC}$ concentrations were frequently lower by a factor of $\sim 2$ in the $\mathrm{ABL}$ relative to values in background air immediately above. These lower concentrations were associated with the moist, halogen-active, $\mathrm{O}_{3}$-depleted portion of the sea-ice inversion layer that indicates chemical interaction with the surface. These observations suggest that dry or wet (ice) deposition may have been occurring within the ABL. Spackman et al. (2010) show evidence of dry deposition of BC in the vicinity of open leads where enhanced vertical mixing may accelerate the dry deposition process. However, differences in airmass histories, and therefore aerosol sources, may also contribute to the observed vertical structure.

Twenty-day airmass histories calculated with the FLEXPART transport model and initialized in the ABL most frequently remained within the Arctic. The modeled air parcels tended to circulate within the North American sector of the Arctic, particularly in the vicinity of the Canadian Arctic archipelago (Fig. 11). In many cases the simulations showed several days of transport within the ABL, preceded by gradual descent from the free troposphere. This transport pattern is consistent with the expected climatological mean circulation of diabatic cooling and descent in the Arctic; as a result the ABL air over the North American Arctic has the longest residence time of any air in the Arctic (Stohl, 2006). Mean mixing ratios of $\mathrm{CO}$ observed in the ABL did not differ significantly from those found in the background free troposphere, indicating that mixing times between these two airmasses were short relative to the many-month timescales of photochemical CO loss in high latitude winter/spring (Novelli et al., 1992). The wide range of possible residence times of air parcels within the ABL - several days to perhaps a month (Stohl, 2006) - suggests that aerosol particles in the ABL could be subject to dry or wet deposition mechanisms over long time scales. Even slow or sporadic deposition processes, perhaps associated with turbulence and moisture fluxes over open leads, could become significant over such periods (Spackman et al., 2010).

\section{Discussion}

\section{1 "Background haze" measurements are consistent with surface climatologies}

Of the four airmass categories, the background haze and ABL groupings are most consistent with aerosol climatologies measured at surface sites. At Barrow, Alaska, long-term 


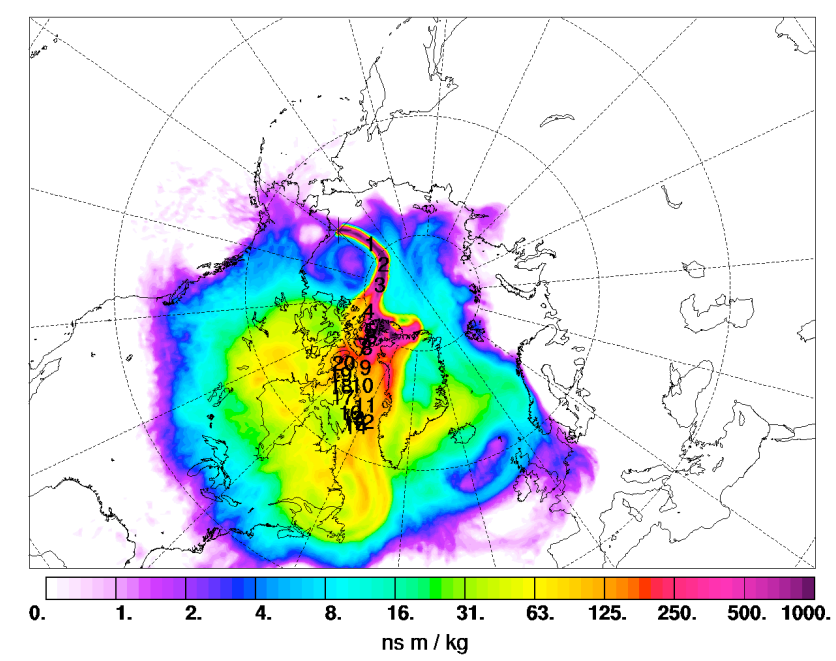

Fig. 11. FLEXPART Lagrangian transport model backward transport simulation of $6 \times 10^{4}$ air particles initialized at the location of the WP-3D aircraft within the ABL on 16 April 2010 at 00:22 UTC. Color scale (logarithmic) is the column-integrated potential emission sensitivity, which is proportional to the cumulative residence time of each particle in a grid cell. Numeric labels show the centroid particle location on each day.

measurements of $\mathrm{CO}$ and submicron aerosol scattering, sulfate concentration, and particle number measured during springtime may be compared with similar measurements aboard the WP-3D aircraft (Fig. 12). Extinction at $532 \mathrm{~nm}$ for the background and $\mathrm{ABL}$ airmass categories lie at the 28th and 18th percentiles of the Barrow $550 \mathrm{~nm}$ scattering data, respectively (scattering and extinction are equivalent to within a few percent), while the airborne sulfate measurements lie at the 73rd and 92nd percentiles of the Barrow measurements for these airmass categories. Although the aerosol measured in background haze conditions was somewhat less light-scattering and had a higher sulfate concentration than the typical surface haze measured at Barrow, these parameters were within the interquartile range of the surface record. Particle number and $\mathrm{CO}$ for both the background and $\mathrm{ABL}$ groupings were also within the interquartile range of the Barrow measurements. Measurements by the WP-3D in the ABL over the remote sea ice consistently showed the lowest concentrations of fine particle number, mass, extinction, and absorption and of $\mathrm{CO}$ and acetonitrile (Fig. 6a to f), yet climatological means measured at the Barrow Observatory were often more similar to the background haze category measured in the free troposphere (Fig. 12). It is possible that the ABL north of Barrow was more aged (Stohl, 2006), or the aerosol more depleted (Spackman et al., 2010), than surface-layer air typically sampled at the Barrow Observatory. In this case the ARCPAC measurements may be more representative of the remote $\mathrm{ABL}$ than those made at Barrow.

www.atmos-chem-phys.net/11/2423/2011/
Layers of enhanced aerosol extinction at $532 \mathrm{~nm}$ observed aloft during ARCPAC, whether originating from biomass/biofuel or fossil fuel sources, were at the high end ( $>94$ th percentile) of the probability distribution function for the $550 \mathrm{~nm}$ Barrow surface observations. Thus these layers were not representative of the typical springtime Arctic haze as measured by surface sites. However, these aerosol layers were similar in terms of scattering and aerosol composition to those measured during many previous airborne measurements in the Arctic (Shaw, 1975; Schnell, 1984; Radke, et al., 1984; Rahn et al., 1977; Clarke et al., 1984; Ottar et al., 1986; Hansen and Novakov, 1989; Brock et al., 1990; Stone et al., 2010). Since the BB haze layers measured during ARCPAC and ARCTAS contained substantial quantities of sulfate, and since earlier airborne campaigns did not measure gas-phase tracers of combustion or organic aerosol mass with sufficient time response to characterize the discontinuous layers, an open question remains regarding how many aerosol haze layers observed in past airborne campaigns were primarily of BB (or mixed BB and fossil fuel) origin.

\subsection{Chronic pollution vs. episodic transport events: defining "Arctic haze"}

In the ARCPAC airborne measurements, locally enhanced aerosol loadings were always associated with mixing ratios of $\mathrm{CO}>170 \mathrm{ppbv}$. Mixing ratios of $\mathrm{CO}$ were rarely $<140 \mathrm{ppbv}$ in the absence of air with a stratospheric influence. The seasonal cycle of $\mathrm{CO}$ at the Barrow surface observatory is pronounced and repeatable from year-to-year, with little variability (5th and 95th percentile mixing ratios are 147 and $176 \mathrm{ppbv}$, respectively). There are only a few episodes of high CO measured at the surface of Barrow (values $>195$ ppbv exceed the 99th percentile), implying that the dense haze layers of particles and $\mathrm{CO}$ frequently found aloft are rarely seen at the surface (although such events have occurred (Stohl et al., 2006)). The limited variability in the springtime values of $\mathrm{CO}$ and aerosol scattering measured at Barrow indicate that the frequency of dense aerosol layers does not determine the climatological seasonal cycle. Instead the seasonal aerosol cycle observed at Barrow is better characterized as a gradual cycle in background conditions. The seasonality of these aerosol properties at Barrow and other surface stations in the Arctic (notably Alert, Canada) provide the canonical definition of "Arctic haze". In contrast, much of the focus of airborne missions has been on dense layers of enhanced aerosol and gas concentrations found aloft; these occurrences have also been termed "Arctic haze" by investigators (e.g., Rahn et al., 1977; Garrett and Verzella, 2008).

Evaluating the ARCPAC data in the context of past surface and airborne measurements in the Arctic, it is apparent that the Arctic aerosol may best be described as having both chronic and episodic characteristics. The low-variance, seasonal cycle of $\mathrm{CO}$ as measured at Arctic surface stations is associated with a similar low-variance, seasonal cycle in 

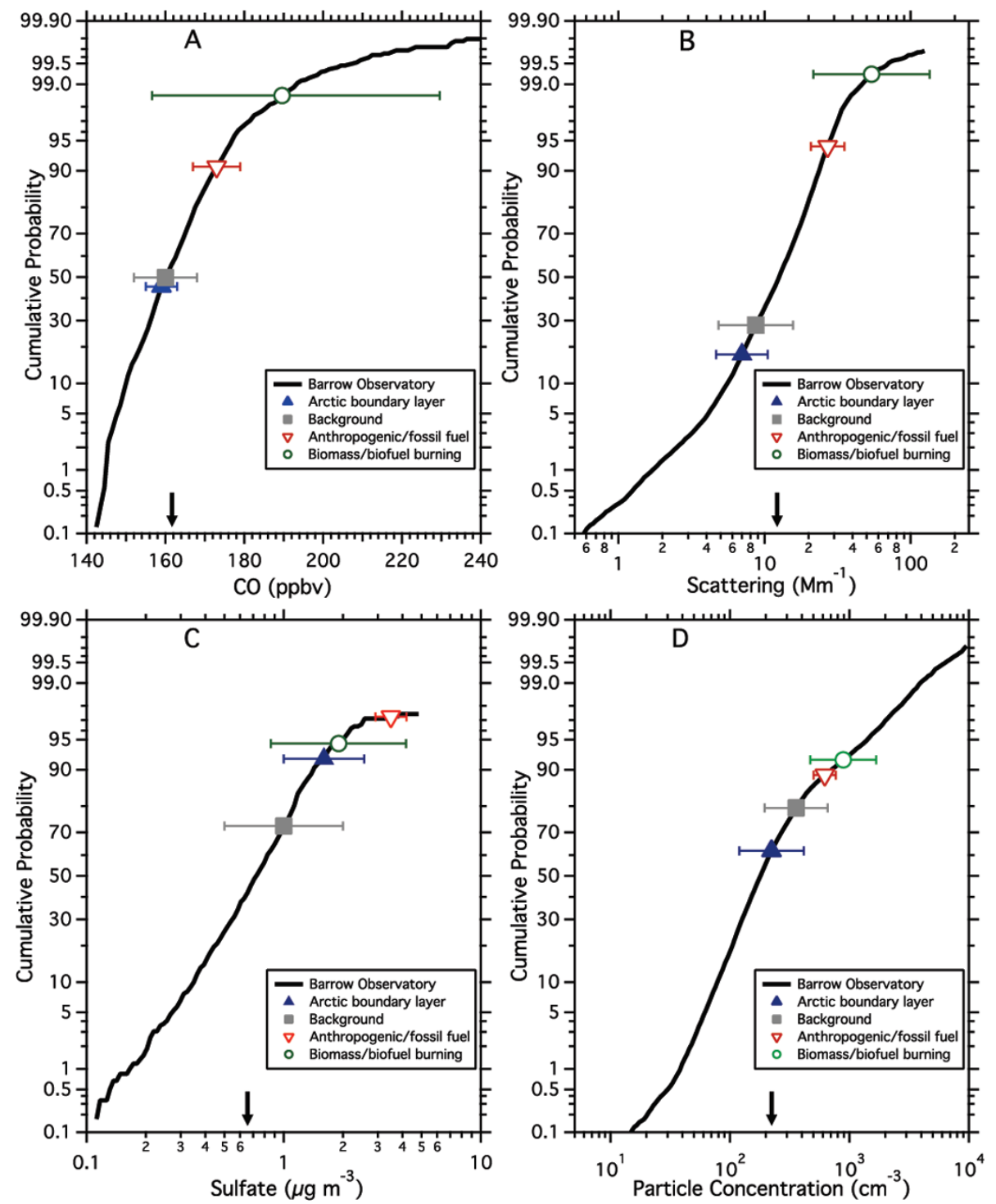

Fig. 12. (A) Cumulative probability distribution of CO measured at the NOAA Baseline Observatory in Barrow, Alaska (Novelli et al., 2008). Data are hourly measurements from February-April over the period 2005-2008. Arrow indicates arithmetic mean value. Data have not been filtered for possible contamination from local sources. Symbols and error bars are the geometric mean and standard deviation for the four airmass classifications (see legend) measured on the NOAA WP-3D during ARCPAC and are positioned vertically on the Barrow cumulative probability distributions. (B) As for (A), but for sub-1 $\mu \mathrm{m}$ light scattering at $550 \mathrm{~nm}$ measured at Barrow from 1987-2008 (line) and sub-1 $\mu \mathrm{m}$ extinction at $532 \mathrm{~nm}$ from the WP-3D during ARCPAC (symbols). Arrow indicates geometric mean value from Barrow. Barrow aerosol data have been filtered for possible contamination from local sources (Delene and Ogren, 2002). (C) As for (B), but for sub-1 $\mu \mathrm{m}$ sulfate measured by the University of Washington over approximately 2-day periods at Barrow from 1997-2008 (line) and sub-1 $\mu \mathrm{m}$ sulfate measured on the NOAA WP-3D during ARCPAC (symbols). (D) As for (B), but for total particle concentrations measured at Barrow (line) and aboard the NOAA WP-3D aircraft (symbols).

aerosol properties (Fig. 12). Multiple, independent lines of evidence, from atmospheric transport studies (e.g., Raatz and Shaw, 1984; Stohl, 2006) to global chemical transport modeling (e.g., Koch and Hansen, 2005; Fisher et al., 2010) to compositional fingerprinting (e.g., Rahn, 1981), point to fossil fuel and biomass/biofuel combustion sources in the northern midlatitudes - especially from northeastern Europe and
Siberia - as the principal source of this chronic pollution near the surface of the Arctic. Arctic haze is best defined as the winter/spring maximum in this seasonal cycle in aerosol and trace gas concentrations. Episodic events are distinct from this seasonal maximum, and are associated with direct, rapid transport from a variety of mid- and northern-latitude sources. These transport events typically take the form of 
dense aerosol layers found at altitudes from above the seaice inversion layer to the upper troposphere (and occasionally at the surface (Stohl, et al., 2006, 2007; Stone et al., 2008)). Due to atmospheric mixing, some of these dense but thin haze layers aloft may ultimately contribute to the chronic Arctic background haze, although Arctic residence times above the surface layer decrease with increasing altitude (Stohl, 2006). We note that long-range transport to the Arctic has been observed in summer as well as in winter and spring (e.g., Brock et al., 1989; Stohl et al., 2006; Paris et al., 2009).

We suggest that the term "Arctic haze" not be used for episodic transport events, despite its common use in the literature, since long-range, intercontinental transport of aerosol layers in the free troposphere is not unique to the Arctic (e.g., Stohl et al., 2002). The sources of the layers associated with episodic transport events in the Arctic appear to be diverse (Fisher et al., 2010). In 2008, unusually early and extensive biomass burning in southeastern Siberia contributed to aerosol layers found over the western Arctic (Warneke et al., 2010). Agricultural fires in southern Russia, which are a regular springtime occurrence (Warneke et al., 2010), also contributed to the aerosol layers observed in the Arctic. Aerosol layers originating from fossil fuel combustion, while infrequent in the ARCPAC dataset, were more common in the wider geographic region sampled by the ARCTAS research DC-8 and P-3B aircraft (Fisher et al., 2010, Jacob et al., 2010), and past airborne measurements have also reported many layers originating from such sources. Transport modeling (Koch and Hansen, 2005; Stohl, 2006; Fisher et al., 2010) and some observations (Scheuer et al., 2003) suggest a seasonally varying transition from high latitude to midlatitude sources with increasing altitude in the Arctic. However, our limited observations do not indicate systematic changes in the characteristics of the background aerosol (chronic Arctic haze) as a function of altitude above the ABL.

\subsection{Background and ABL aerosol contains a biomass or biofuel burning component}

The background Arctic haze submicron non-refractory aerosol mass measured during ARCPAC was approximately 2/3 inorganic material and 1/3 organic compounds (Fig. 7). The PALMS instrument reported that $64 \%$ by number of the fine mode particles were classified as containing a biomass burning component based on potassium and organic carbon marker ions, following the scheme of Hudson et al. (2004). This fraction is noticeably higher than typical levels of 20 to $40 \%$ that are consistently observed throughout the midlatitude and tropical troposphere (Hudson et al., 2004; Froyd et al., 2009). The FLEXPART model predicts a small but detectable BB influence on Arctic air from fires in northern Asia and other mid-latitude regions prior to the ARCPAC measurement period (Warneke et al., 2010). It is likely that these earlier plumes were partially entrained into the background Arctic air, enhancing the BB aerosol fraction. Based on the observed coexistence on single particles of condensed material such as sulfate, ammonium, and lead with the BB marker species, BB particles in background air were more aged than those within the intense BB aerosol layers, consistent with earlier emission from sources and longer atmospheric residence times. In the ABL the BB particle fraction $(31 \%)$ was near typical mid-latitude free tropospheric values, but signatures of particle aging were even stronger than in background air aloft. In particular, the high sulfate content in the single particle mass spectra suggests extensive aging (Hudson et al., 2004). The observed low concentrations of VOCs, as well as the FLEXPART transport simulations, indicate that $\mathrm{ABL}$ air was isolated to Arctic regions for the previous few weeks and had little recent influence from mid-latitude emission sources. The source of BB aerosol material in the springtime background haze and in the ABL is presumably the same as the seasonally enhanced $\mathrm{CO}$, i.e., winter and spring emissions from northern midlatitudes. In northern Europe during the cold season, wood burned for heating creates smoke that is co-emitted with anthropogenic pollution (Gelencsér et al., 2007; Yttri et al., 2009). Both this cold-season biofuel source and mid-latitude springtime fires likely contribute to the seasonal background of $\mathrm{BB}$ aerosol material found in free tropospheric Arctic air.

\subsection{No evidence of precipitation scavenging from layers aloft}

Black carbon deposited on snow is a potentially significant climate forcing agent in the Arctic (Hansen and Nazarenko, 2004; Jacobson, 2004, 2010; Flanner et al., 2007, 2009; Shindell et al., 2008; Shindell and Faluvegi, 2009). It is important to understand the origin of the $\mathrm{BC}$ that has been observed in snow at the surface of the Arctic if effective mitigation strategies are to be developed (Quinn et al., 2008). Both airborne $\mathrm{BC}$ concentrations and precipitation rates are low in the Arctic, making direct measurements of depositional flux rare (Noone and Clarke, 1988; Doherty, et al., 2010). Recent analysis based on compositional measurements of snow samples collected across the Arctic in springtime indicate a dominant biomass and/or biofuel burning source over much of the Arctic (Hegg et al. 2009, 2010; Doherty et al., 2010).

Since snow compositional measurements suggest a biomass/biofuel burning source, one might expect to see evidence for wet deposition of particles from the BB layers observed aloft during ARCPAC. In 2004 measurements near the eastern coast of North America, we found regions highly enhanced in gas-phase BB markers but relatively depleted with respect to aerosols and highly soluble gas-phase species, and have interpreted these observations as evidence for wet deposition (de Gouw et al., 2006). In ARCPAC, CO mixing ratios and aerosol mass (estimated from volume) were highly correlated in plumes that were enhanced in acetonitrile (Fig. 13). However, there were no cases during ARCPAC in which CO 
or acetonitrile were enhanced yet aerosol number and mass concentrations were not. Instead, the slope between aerosol mass and $\mathrm{CO}$ stands at the high end of literature values for particle emissions from biomass burning sources (Fig. 13).

Dry deposition might occur if the smoke aerosol were mixed to near the sea-ice surface. However, the dense aerosol layers observed aloft during ARCPAC were decoupled from the sea-ice $\mathrm{ABL}$ due to persistent strong inversions, and there was no indication of direct mixing of the $\mathrm{BB}$ aerosol plumes aloft to the sea-ice surface layer over the time scales of the ARCPAC measurements. On one occasion, BB smoke measured on 19 April 2010 over the Barrow airport reached the lowest altitude, $\sim 70 \mathrm{~m}$, sampled by the WP-3D aircraft. However, this measurement was over land rather than seaice, and occurred as a result of strong warm advection within a midlatitude airmass rather than mixing from aloft into the ABL. Smoke associated with this transport event was found aloft above the ABL over sea-ice north of Barrow (Lance et al., 2011).

Spackman et al. (2010) report evidence for dry deposition of $\mathrm{BC}$ and other aerosol constituents within the ABL; this is the only evidence of loss of aerosol particles to the surface found during ARCPAC. This deposition mechanism appeared to operate over the lowest few hundred meters within the ABL over sea-ice, and thus did not directly act upon the dense layers that were found only aloft, above the sea-ice inversion layer.

\subsection{Arctic aerosol produces heating aloft and cooling at the surface}

While there is no evidence that the BB particles in layers observed aloft during ARCPAC deposited to the snow, the direct radiative forcing of the aerosol layers remains of potential significance. To evaluate this effect, aerosol direct radiative forcing was calculated for the shortwave spectrum as the difference in flux with and without aerosol. The radiative transfer model used for the calculations was the Santa Barbara DISORT Atmospheric Radiative Transfer model (SBDART; Ricchiazzi et al., 1998) implemented as described in McComiskey et al. (2008).

In this 1st-order modeling exercise, a solar zenith angle (SZA) of 60 degrees, which represents a maximum daily solar elevation for ARCPAC latitudes, was assumed, as was a surface albedo of 0.85 , which is the average April value from a 10 year climatology at Barrow (calculated from data collected by the Department of Energy ARM Climate Research Facility). A standard Arctic profile of absorbing gases (McClatchey et al., 1972) was used. Holding all of these factors constant allows us to focus on the maximum possible forcing caused by the aerosol alone under representative Arctic conditions. More complete radiative transfer modeling constrained by spectrally resolved actinic flux and irradiance measurements (Bierwirth et al., 2010) under varying

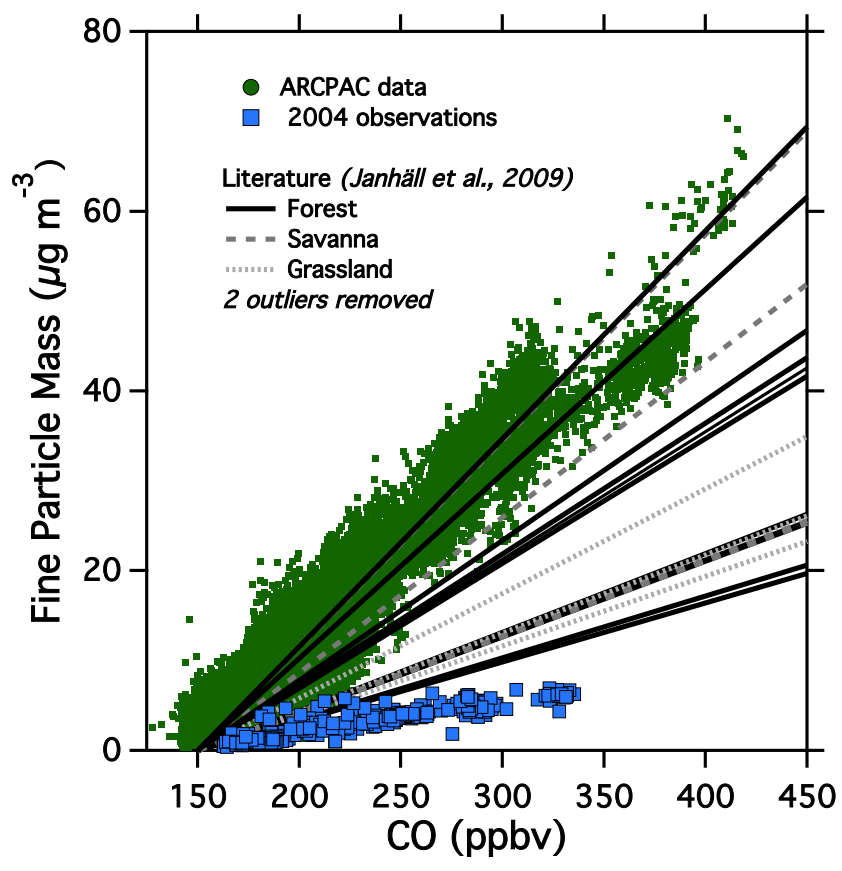

Fig. 13. Particle mass as a function of $\mathrm{CO}$ for all data classified as biomass/biofuel burning during ARCPAC (dots). Mass calculated from particle volume measurements and density of 1.36 determined from AMS composition measurements in BB plumes. Squares are data from a BB case in 28 July 2004 in which precipitation scavenging occurred (de Gouw et al., 2006) with CO values adjusted to intercept the $x$-axis at $150 \mathrm{ppbv}$ to facilitate comparison with ARCPAC data. Lines are fits to measurements in a variety of prescribed, laboratory, and wild fires as summarized in Janhäll et al. (2009), except that 2 outliers have been removed and an $\mathrm{x}$-intercept of 150 ppbv assigned.

surface albedos and SZA conditions, will be the subject of future work.

Ambient values of light extinction were calculated from ambient RH measurements using the mean $\gamma$ values at $532 \mathrm{~nm}$ for each airmass category (Table 3 ). Single scattering albedo was recalculated using this ambient extinction value and the dry absorption measurement. A fixed asymmetry parameter of 0.65 , lying between the values calculated from the dry size distributions (Table 3) and values reported for Barrow, Alaska, was used. McComiskey et al. (2008) show that radiative forcing sensitivity to varying asymmetry parameter in these Arctic conditions is negligible. From the entire ARCPAC campaign, ten representative profiles, including sampling in all four regimes (Fig. 14a), of ambient extinction and SSA derived from the observations were averaged into $150 \mathrm{~m}$ bins from the surface to $8 \mathrm{~km}$ for the radiative transfer calculations (Fig. 14b,c). Our calculations do not consider the effect of changes in the solar radiative balance on IR emissions (e.g., Pueschel and Kinne, 1995), a subject complicated by strong sensitivities to surface, atmospheric, and cloud characteristics (e.g., Stone et al., 2008). 

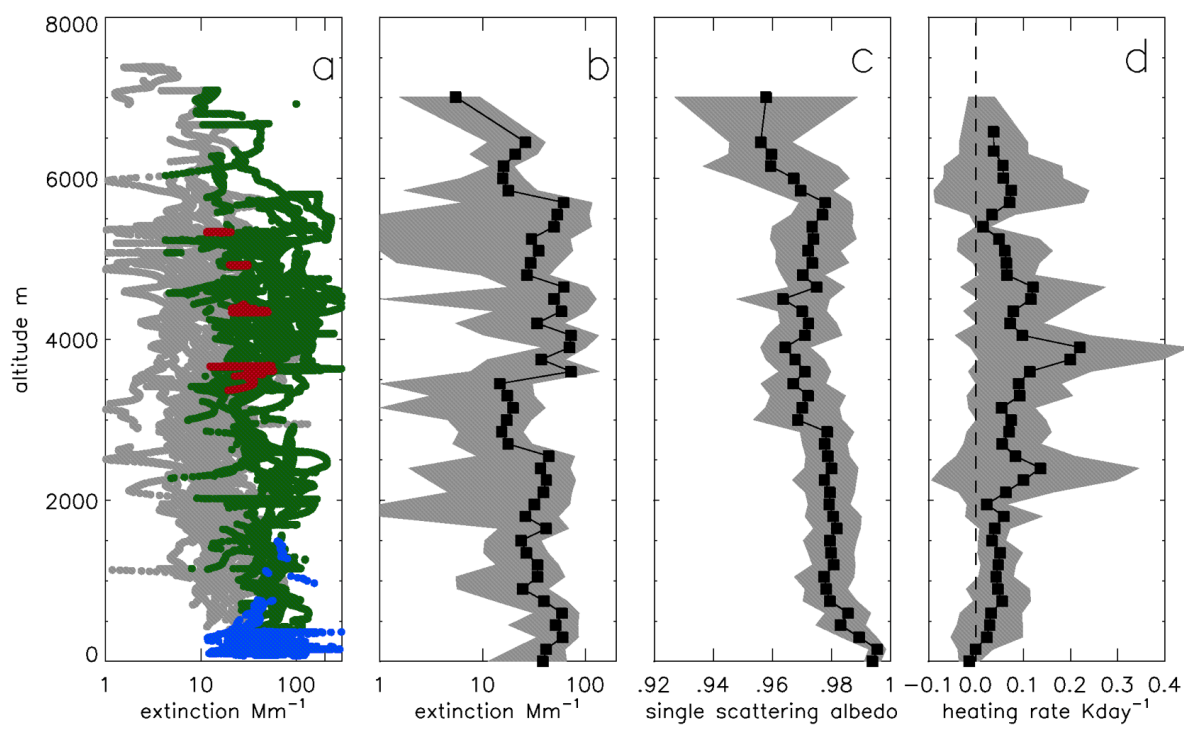

Fig. 14. (A) Vertical profiles of ambient aerosol extinction determined from dry extinction measurements corrected to ambient humidity and air density. Biomass burning (green points), Arctic sea-ice boundary layer (blue), background (grey), and anthropogenic (red) airmass classifications. (B) Data from (A) averaged into $150 \mathrm{~m}$ altitude bins. (C) Aerosol single scattering albedo averaged into $150 \mathrm{~m}$ increments. (D) Calculated instantaneous noontime heating rate given by average profiles in (B) and (C) and other parameters as specified in text. Grey shading indicates one standard deviation for each $150 \mathrm{~m}$ bin.

The average of the results of the radiative transfer calculations for each the 10 binned vertical profiles are shown in Fig. 14d. Average heating rates of $\sim 0.1 \mathrm{~K} \mathrm{day}^{-1}$ occurred between 3 and $7 \mathrm{~km}$, where most of the BB layers were observed, with a maximum value of the average profile of $\sim 0.2 \mathrm{~K} \mathrm{day}^{-1}$. However, this maximum heating varied substantially with individual profiles depending on the properties of the aerosol layer, surface albedo, and height above the surface. Layers with maximum heating rates of $\sim 0.6 \mathrm{~K} \mathrm{day}^{-1}$ were calculated for individual profiles. The top-of-atmosphere radiative forcing for the average profile was $+3.3 \mathrm{~W} \mathrm{~m}^{-2}$, while surface forcing was $-1.5 \mathrm{~W} \mathrm{~m}^{-2}$ and tropospheric column forcing $+4.8 \mathrm{~W} \mathrm{~m}^{-2}$. Note that these values are for the instantaneous forcings calculated at solar noon, which is the maximum possible. Diurnally averaged values would be lower. These values can be compared to surface in situ measurements at Barrow, Alaska for a representative case of Arctic haze (Quinn et al., 2007). For this case, calculations were made at solar noon on April 15, similar solar geometry to our calculations, and with a surface albedo of 0.92 , higher than our average value of 0.85 . This case resulted in top-of-atmosphere forcing of $+2.5 \mathrm{~W} \mathrm{~m}^{-2}$ and surface forcing of $-0.93 \mathrm{~W} \mathrm{~m}^{-2}$, resulting in a tropospheric forcing of $3.43 \mathrm{~W} \mathrm{~m}^{-2}$. These calculations show that the short term effects of both the background haze and dense haze layers aloft are to cool the surface and heat the atmospheric column, while producing net energy absorption by the earth-atmosphere system. These preliminary findings are consistent with more complete studies of the effects of
BB plumes (Stone et al., 2008) and dust layers (Stone et al., 2007) over Barrow, Alaska on the surface-radiation balance. In their Fig. 10, Stone et al. (2008) show a strong sensitivity of both instantaneous surface and TOA radiative forcing to surface albedo. Net atmospheric cooling occurs when BB smoke is present over dark tundra and open water, but net radiative heating occurs when the smoke overlies brighter, snow-covered surfaces. These authors also point out that such surface cooling, coupled with heating aloft within the BB layers, may change the thermal structure of the atmosphere to potentially modify atmospheric circulation and cloud formation.

Finally, to examine the relative radiative forcing of the four aerosol classifications, a column integrated radiative forcing efficiency (RFE), the radiative forcing per unit optical depth, was calculated (Table 4). For the same optical depth, the background, BB, and anthropogenic regimes have larger positive top-of-atmosphere and tropospheric column forcing and more negative surface forcing than does the ABL case. As discussed in Section 4.1, observations at Barrow, Alaska capture well the seasonal cycle of the background aerosol and would thus accurately characterize the vertically integrated forcing associated with the background haze classification. However, when ABL air, with its depleted aerosol concentrations and high single scatter albedo, is present, in situ measurements at the surface will not accurately represent aerosol characteristics for the calculation of radiative forcing. 
Table 4. Radiative forcing efficiency $\left(\mathrm{W} \mathrm{m}^{-2} \tau^{-1}\right)$, the radiative forcing per optical depth, to the top-of-atmosphere, atmosphere, and surface for the four aerosol regimes measured during ARCPAC.

\begin{tabular}{lrrrr}
\hline & ABL & Background & Anthropogenic & BB \\
\hline Top-of-atmosphere & 2.0 & 32.9 & 29.2 & 37.6 \\
Troposphere & 10.2 & 44.3 & 41.5 & 50.4 \\
Surface & -8.3 & -11.4 & -12.3 & -12.8 \\
\hline
\end{tabular}

\section{Conclusions}

Airborne measurements from the NOAA WP-3D aircraft in April 2008 in the Alaskan Arctic could be placed into one of four categories based on trace gas mixing ratios: (1) air measured within the ABL that had been in chemical and physical contact with the sea-ice surface; (2) air that was strongly influenced by BB originating primarily from sources in southern Russia and in southeastern Siberia; (3) air that was affected primarily by anthropogenic fossil fuel combustion sources; and (4) air that was not influenced by any recent source, but that represented the aged, polluted background of the springtime Arctic.

Aerosol layers associated with transport from the BB events were common in the Alaskan Arctic in spring 2008. The aerosol was often abundant and was highly scattering with single scattering albedos of $\sim 0.97$. Radiative transfer calculations suggest that, on average, these haze layers cool the surface and heat the troposphere at the altitude where they are found. Maximum noontime heating rates of $\sim 0.1 \mathrm{~K} \mathrm{day}^{-1}$ were calculated for the average haze condition, although maximum heating rates of $\sim 0.6 \mathrm{~K} \mathrm{day}^{-1}$ were calculated for specific dense haze layers. Warneke et al. (2010) and Fisher et al. (2010) show that, although the incidence of fires in the Russian/Siberian fire region was $\sim 3$ times greater in 2008 compared to more typical years, significant fires occur somewhere within the region from southern Russia to southeastern Siberia every year. These fires are modest contributors to the Arctic budgets of most gas-phase species, including CO. However, because the springtime midlatitude fires are prodigious producers of particles (per $\mathrm{CO}$ molecule emitted, Fig. 13), and because the background Arctic haze aerosol is relatively diffuse, they have a very large impact on the Arctic aerosol budget compared to the background haze, contributing $\sim 30 \%$ of the total aerosol mass and $\sim 45 \%$ of the total $\mathrm{BC}$ mass poleward of $70^{\circ} \mathrm{N}$ in a typical fire year (Warneke et al., 2010), not accounting for the presence of dense layers from fossil fuel sources. Furthermore, while the most dense smoke observed during ARCPAC was primarily confined to the Alaskan Arctic, transport modeling (Fig. 10, Supplementary Material) and pan-Arctic sunphotometry and lidar observations (Saha et al., 2010) show significant smoke over much of the Arctic region poleward of $70^{\circ} \mathrm{N}$ by the end of April 2008. Thus springtime midlatitude
Eurasian BB emissions represent a consequential source of aerosol to the entire Arctic region during the snowmelt season. The strongly differing burning patterns across political boundaries (Fig. 9) demonstrate that fire management policies can greatly affect emissions from BB during the Arctic snowmelt season

Our measurements in Arctic background air are consistent with previously reported surface observations suggesting that $\sim 25 \%$ of the non-sea-salt submicron mass during the Arctic haze season is organic (Quinn et al., 2002). Single particle composition measurements in the background Arctic airmass suggest that biomass and/or biofuel combustion contributes to this organic fraction, while fossil fuel emissions contribute most of the sulfate in the background haze. Gasphase and aerosol parameters measured in these background haze conditions are similar to median values reported during the springtime Arctic haze maximum at the long-term surface site in Barrow, Alaska. These observations strongly suggest that a seasonal cycle in background tropospheric concentrations, rather than an increase in the frequency of intense pollutant transport events, is responsible for the surface climatology. We suggest that the term "Arctic haze" be used to refer to this chronic, diffuse springtime pollution that is associated with seasonal increases in fossil fuel and biomass/biofuel emissions, reductions in photochemical and depositional loss mechanisms, and enhanced transport from source regions in the midlatitudes. Spackman et al. (2010) provide evidence for loss of this background haze via transport through the ABL to the Arctic surface. In contrast, episodic pollution events, resulting from rapid transport from heavily polluted but varied source types and regions, produce dense haze layers aloft that rarely directly reach the surface monitoring sites; these phenomena are distinct from the seasonal cycle in background haze. These haze layers aloft are not unique to the Arctic, but are consistent with observations throughout the midlatitudes of intercontinental transport of aerosols in the free troposphere. In the Arctic, it is likely that some fraction of these layers may ultimately mix and contribute to the polluted background, although Arctic lidar observations show distinct layering of even aged smoke (Saha et al., 2010). Our observations do not provide any direct evidence for deposition from these layers aloft to the snow surface.

Acknowledgements. This work was supported by NOAA's Climate Change and Air Quality Programs. P. Pilewskie and S. Schmidt were supported by NOAA under award NA06OAR4310085. A. Nenes and R. Moore were supported by NOAA award NA04OAR4310088 and NASA award NNX08AQ99G. A. Nenes was also supported by a NSF Faculty Early Career Development (CAREER) Program award, and R. Moore by a DOE Global Change Education Program Graduate Research Fellowship. S. Lance was supported by the US National Research Council under a Research Associateships Program fellowship, and J. Cozic by the Swiss National Science Foundation under award PBBE22-119260. A. Stohl and H. Sodemann were supported by the Research Council of Norway in the framework of POLARCAT. MODIS hotspot data provided courtesy of NASA and the University of Maryland. Thanks to Jim Roberts, Andy Neuman, and Bob Stone 
for constructive comments on the manuscript, to the collaborating ISDAC, ARCTAS, ICEALOT, and other POLARCAT participants, and to Everts Air in Fairbanks, Alaska for outstanding logistical support. Finally, a special note of thanks to Glen Shaw and Bill Simpson of the University of Alaska at Fairbanks, who led enthusiastic material, scientific, and institutional support for all of the IPY projects in Fairbanks.

Edited by: K. Law

\section{Supplementary material related to this article is available online at: http://www.atmos-chem-phys.net/11/2423/2011/ acp-11-2423-2011-supplement.zip.}

\section{References}

Al-Saadi, J. A., Soja, A., Pierce, R. B., Szykman, J. J., Wiedinmyer, C., Emmons, L., Kondragunta, S., Zhang, X., Kittaka, C., Schaack, T., and Bowman, K.: Intercomparison of near-real-time biomass burning emissions estimates constrained by satellite active fire data, J. Appl. Remote Sens., 2, 021504, 2008.

Alterskjær, K., Hoose, C., and Kristjánsson, J. E.: Do anthropogenic aerosols enhance or suppress the surface cloud forcing in the Arctic?, J. Geophys. Res., 115, D22204, doi:10.1029/2010JD014015, doi:10.1029/2010JD014015, 2010.

Andreae, M. O., and Merlet, P.: Emission of trace gases and aerosols from biomass burning, Global Biogeochem. Cy., 15, 955-966, 2001.

Andreas E. L. and Murphy, B.: Bulk transfer coefficients for heat and momentum over leads and polynyas, J. Phys. Oceanogr., 16, 1875-1883, 1986.

Andreas, E. L., Guest, P. S., Persson, P. O. G., Fairall, C. W., Horst, T. W., Moritz, R. E., and Semmer, S. R.: Near-surface water vapor over polar sea-ice is always near ice saturation, J. Geophys. Res., 107, 8101, doi:10.1029/2000JC000411, 2002.

Bahreini, R., Dunlea, E. J., Matthew, B. M., Simons, C., Docherty, K. S., DeCarlo, P. F., Jimenez, J. L., Brock, C. A., and Middlebrook, A. M.: Design and operation of a pressure-controlled inlet for airborne sampling with an aerodynamic aerosol lens, Aerosol Sci. Tech., 42, 465-471, 2008.

Barrie, L. A.: Arctic air pollution: An overview of current knowledge, Atmos. Environ., 20, 643-663, 1986.

Baumgardner, D., Jonsson, H., Dawson, W., O'Connor, D., and Newton, R.: The cloud, aerosol and precipitation spectrometer: a new instrument for cloud investigations, Atmos. Res., 59-60, 251-264, doi:10.1016/S0169-8095(01)00119-3, 2001.

Baynard, T., Lovejoy, E. R., Pettersson, A., Brown, S. S., Lack, D., Osthoff, H., Massoli, P., Ciciora, S., Dubé, W. P., and Ravishankara, A. R.: Design and application of a pulsed cavity ringdown aerosol extinction spectrometer for field measurements, Aerosol Sci. Technol., 41, 447-462, 2007.

Bierwirth, E., Wendisch, M., Jäkel, E., Ehrlich, A., Schmidt, K. S., Stark, H., Pilewskie, P., Esselborn, M., Gobbi, G. P., Ferrare, R., Müller, T., and Clarke, A.: A new method to retrieve the aerosol layer absorption coefficient from airborne flux density and ac- tinic radiation measurements, J. Geophys. Res., 115, D14211, doi:10.1029/2009JD013636, 2010.

Bodhaine, B. A.: Barrow surface aerosol: 1976-1986, Atmos. Environ., 23, 2357-2369, 1989.

Bohren, C. F. and Huffman, D. R.: Absorption and Scattering of Light by Small Particles, J. Wiley and Sons, NY, ISBN 0-47105772-X, 1983.

Bond, T. C. and Bergstrom, R. W.: Light absorption by carbonaceous particles: An investigative review, Aerosol. Sci. Technol., 40, 27-67, doi:10.1080/02786820500421521, 2006.

Bond, T. C., Anderson, T. L., and Campbell, D.: Calibration and Intercomparison of Filter-Based Measurements of Visible Light Absorption by Aerosols. Aerosol Sci. Technol., 30, 582-600, 1999.

Bond, T. C., Streets, D. G., Yarber, K. F., Nelson, S. M., Woo, J.H., and Klimont, Z.: A technology-based global inventory of black and organic carbon emissions from combustion, J. Geophys. Res., 109, D14203, doi:10.1029/2003JD003697, 2004.

Brock, C. A., Radke, L. F., Lyons, J. H., and Hobbs, P. V.: Arctic hazes in summer over Greenland and the North American Arctic. I. Incidence and origins, J. Atmos. Chem., 9, 129-148, 1989.

Brock, C. A., Radke, L. F., and Hobbs, P. V: Sulfur in particles in Arctic hazes derived from airborne in situ and lidar measurements, J. Geophys. Res, 95, 22369-22387, 1990.

Brock, C. A., Schröder, F., Kärcher, B., Petzold, A., Busen, R., and Fiebig, M.: Ultrafine particle size distributions measured in aircraft exhaust plumes, J. Geophys. Res., 105, 26,555-26,567, 2000.

Brock, C. A., Hudson, P. K., Lovejoy, E. R., Sullivan, A., Nowak, J. B., Huey, L. G., Cooper, O. R., Cziczo, D. J., de Gouw, J., Fehsenfeld, F. C., Holloway, J. S., Hübler, G., Lafleur, B. G., Murphy, D. M., Neuman, J. A., Nicks Jr., D. K., Orsini, D. A., Parrish, D. D., Ryerson, T. B., Tanner, D. J., Warneke, C., Weber, R. J., and Wilson, J. C.: Particle characteristics following cloud-modified transport from Asia to North America, J. Geophys. Res., 109, D2336, doi:10.1029/2003JD004198, 2004.

Brock, C. A., Sullivan, A. P., Peltier, R. E., Weber, R. J., Wollny, A., de Gouw, J. A., Middlebrook, A. M., Atlas, E. L., Stohl, A., Trainer, M. K., Cooper, O. R., Fehsenfeld, F. C., Frost, G. J., Holloway, J. S., Hübler, G., Neuman, J. A., Ryerson, T. B., Warneke, C., and Wilson, J. C.: Sources of particulate matter in the northeastern United States in summer: 2. Evolution of chemical and microphysical properties, J. Geophys. Res., 113, D08302, doi:10.1029/2007JD009241, 2008.

Cai, Y., Montague, D. C., Mooiweer-Bryan, W., and Deshler, T.: Performance characteristics of the ultra high sensitivity aerosol spectrometer for particles between 55 and $800 \mathrm{~nm}$ : Laboratory and field studies, J. Aerosol Sci., 39, 759-769, doi:10.1016/j.jaerosci.2008.04.007, 2008.

Chapman, W. L. and Walsh, J. E.: Simulations of Arctic temperature and pressure by global coupled models, J. Clim., 20, 609632, 2007.

Chin, M., Ginoux, P., Lucchesi, R., Huebert, B., Weber, R., Anderson, T., Masonis, S., Blomquist, B., Bandy, A., and Thornton, D.: A global aerosol model forecast for the ACE-Asia field experiment, J. Geophys. Res., 108, 8654, doi:10.1029/2003JD003642, 2003.

Clarke, A. D., Charlson, R. J., and Radke, L. F.: Airborne observations of Arctic aerosol, IV: Optical properties 
of Arctic haze, Geophys. Res. Lett., 11, 405-408, doi:10.1029/GL011i005p00405, 1984.

Clarke, A. Collins, W. , Rasch, P., Kapustin, V., Moore, K., Howell, S., and Fuelberg, H.: Dust and pollution transport on global scales: Aerosol measurements and model predictions, J. Geophys. Res., 106, 32555-32569, 2001.

Corbett, J. J., Lack, D. A., Winebrake, J. J., Harder, S., Silberman, J. A., and Gold, M.: Arctic shipping emissions inventories and future scenarios, Atmos. Chem. Phys., 10, 9689-9704, doi:10.5194/acp-10-9689-2010, 2010.

Cziczo, D. J., Murphy, D. M., Hudson, P. K., and Thomson, D. S.: Single particle measurements of the chemical composition of cirrus ice residue during CRYSTAL-FACE, J. Geophys. Res., 109, D04201, doi:10.1029/2003JD004032, 2004.

de Gouw, J. A., Warneke, C. , Karl, T., Eerdekens, G., van der Veen, C., and Fall, R.: Sensitivity and specificity of atmospheric trace gas detection by proton-transfer-reaction mass spectrometry, Int. J. Mass Spectrom., 223-224, 365-382, 2003a.

de Gouw, J. A., Warneke, C., Parrish, D. D., Holloway, J. S., Trainer, M., and Fehsenfeld, F. C.: Emission sources and ocean uptake of acetonitrile $\left(\mathrm{CH}_{3} \mathrm{CN}\right)$ in the atmosphere, J. Geophys. Res., 108, 4329, doi:10.1029/2002JD002897, 2003b.

de Gouw J. A., Warneke, C., Stohl, A., Wollny, A. G., Brock, C. A., Cooper, O. R., Holloway, J. S., Trainer, M., Fehsenfeld, F. C., Atlas, E. L., Donnelly, S. G., Stroud, V., and Lueb, R.: Volatile organic compounds composition of merged and aged forest fire plumes from Alaska and western Canada, J. Geophys. Res., 111, D10303, doi:10.1029/2005JD006175, 2006.

de Gouw, J. and Warneke, C.: Measurements of volatile organic compounds in the earth's atmosphere using proton-transferreaction mass spectrometry, Mass Spectrom. Rev., 26, 223-257, doi:210.1002/mas.20119, 2007.

Delene, D. J. and Ogren, J. A. : Variability of aerosol optical properties at four North American surface monitoring sites, J. Atmos. Sci., 59, 1135-1150, 2002.

Dentener, F., Kinne, S., Bond, T., Boucher, O., Cofala, J., Generoso, S., Ginoux, P., Gong, S., Hoelzemann, J. J., Ito, A., Marelli, L., Penner, J. E., Putaud, J.-P., Textor, C., Schulz, M., van der Werf, G. R., and Wilson, J.: Emissions of primary aerosol and precursor gases in the years 2000 and 1750 prescribed data-sets for AeroCom, Atmos. Chem. Phys., 6, 4321-4344, 2006, http://www.atmos-chem-phys.net/6/4321/2006/.

Dick, W. D. , Ziemann, P. J., and McMurry, P. H.: Multiangle light-scattering measurements of refractive index of submicron atmospheric particles, Aerosol Sci. Technol., 41(5), 549-569, doi:10.1080/02786820701272012, 2007.

Doherty, S. J., Quinn, P. K., Jefferson, A., Carrico, C. M., Anderson, T. L., and Hegg, D.: A comparison and summary of aerosol optical properties as observed in situ from aircraft, ship, and land during ACE-Asia, J. Geophys. Res., 110, D04201, doi:10.1029/2004JD004964, 2005.

Doherty, S. J., Warren, S. G., Grenfell, T. C., Clarke, A. D., and Brandt, R. E.: Light-absorbing impurities in Arctic snow, Atmos. Chem. Phys., 10, 11647-11680, doi:10.5194/acp-1011647-2010, 2010.

Donahue N, Robinson A, and Pandis N.: Atmospheric organic particulate matter from smoke to secondary organic aerosol, Atmos. Environ., 43, 94-106, doi:10.1016/j.atmosenv.2008.09.055, 2009.
Dunlea, E. J., DeCarlo, P. F., Aiken, A. C., Kimmel, J. R., Peltier, R. E., Weber, R. J., Tomlinson, J., Collins, D. R., Shinozuka, Y., McNaughton, C. S., Howell, S. G., Clarke, A. D., Emmons, L. K., Apel, E. C., Pfister, G. G., van Donkelaar, A., Martin, R. V., Millet, D. B., Heald, C. L., and Jimenez, J. L.: Evolution of Asian aerosols during transpacific transport in INTEX-B, Atmos. Chem. Phys., 9, 7257-7287, doi:10.5194/acp-9-7257-2009, 2009.

Fiebig, M. and Ogren, J. A.: Retrieval and climatology of the aerosol asymmetry parameter in the NOAA aerosol monitoring network, J. Geophys. Res., 111, D21204, doi:10.1029/2005JD006545, 2006.

Fisher, J. A., Jacob, D. J., Purdy, M. T., Kopacz, M., Le Sager, P., Carouge, C., Holmes, C. D., Yantosca, R. M., Batchelor, R. L., Strong, K., Diskin, G. S., Fuelberg, H. E., Holloway, J. S., Hyer, E. J., McMillan, W. W., Warner, J., Streets, D. G., Zhang, Q., Wang, Y., and Wu, S.: Source attribution and interannual variability of Arctic pollution in spring constrained by aircraft (ARCTAS, ARCPAC) and satellite (AIRS) observations of carbon monoxide, Atmos. Chem. Phys., 10, 977-996, doi:10.5194/acp-10-977-2010, 2010.

Flanner, M. G., Zender, C. S., Randerson, J. T., and Rasch, P. J.: Present-day climate forcing and response from black carbon in snow, J. Geophys. Res., 112, D11202, doi:10.1029/2006JD008003, 2007.

Flanner, M. G., Zender, C. S., Hess, P. G., Mahowald, N. M., Painter, T. H., Ramanathan, V., and Rasch, P. J.: Springtime warming and reduced snow cover from carbonaceous particles, Atmos. Chem. Phys., 9, 2481-2497, doi:10.5194/acp-9-24812009, 2009.

Francis, J. A. and Hunter, E.: New insight into the disappearing Arctic sea-ice, EOS Trans. Am. Geophys. Union., 87, 46, 509524, 2006.

Frost, G. J., McKeen, S. A., Trainer, M., Ryerson, T. B., Neuman, J. A., Roberts, J. M., Swanson, A., Holloway, J. S., Sueper, D. T., Fortin, T., Parrish, D. D., Fehsenfeld, F. C., Flocke, F., Peckham, S. E., Grell, G. A., Kowal, D., Cartwright, J., Auerbach, N., and Habermann, T.: Effects of changing power plant $\mathrm{NO}_{\mathrm{x}}$ emissions on ozone in the eastern United States: Proof of concept, J. Geophys. Res., 111, D12306, doi:10.1029/2005JD006354, 2006.

Froyd, K. D., Murphy, D. M., Sanford, T. J., Thomson, D. S., Wilson, J. C., Pfister, L., and Lait, L.: Aerosol composition of the tropical upper troposphere, Atmos. Chem. Phys., 9, 4363-4385, doi:10.5194/acp-9-4363-2009, 2009.

Fuelberg, H. E., Harrigan, D. L., and Sessions, W.: A meteorological overview of the ARCTAS 2008 mission, Atmos. Chem. Phys., 10, 817-842, doi:10.5194/acp-10-817-2010, 2010.

Garrett, T. J. and Verzella, L. L.: An evolving history of Arctic aerosols, Bull. Amer. Meteor. Soc., March, 299-302, doi:10.1175/BAMS-89-3-299, 2008.

Garrett, T. J. and Zhao, C.: Increased Arctic cloud longwave emissivity associated with pollution from mid-latitudes, Nature, 440, 787-789, doi:10.1038/nature04636, 2006.

Gelencsér, A., May, B., Simpson, D., Sánchez-Ochoa, A., Kasper-Giebl, A., Puxbaum, H., Caseiro, A., Pio, C., and Legrand, M.: Source apportionment of PM2.5 organic aerosol over Europe: Primary/secondary, natural/anthropogenic, and fossil/biogenic origin, J. Geophys. Res., 112, D23S04, doi:10.1029/2006JD008094, 2007. 
Hansen, A. D. A. and Novakov, T.: Aerosol black carbon measurements in the Arctic haze during AGASP-II, J. Atmos. Chem., 9, 347-361, doi:10.1007/BF00052842, 1989.

Hansen, J. and Nazarenko, L.: Soot climate forcing via snow and ice albedos, Proc. Natl. Acad. Sci., 101, 423-428, 2004.

Hansen, J., Sato, M., Ruedy, R., Nazarenko, L., Lacis, A., Schmidt, G. A., Russell, G., Aleinov, I., Bauer, M., Bauer, S., Bell, N., Cairns, B., Canuto, V., Chandler, M., Cheng, Y., Del Genio, A., Faluvegi, G., Fleming, E., Friend, A., Hall, T., Jackman, C., Kelley, M., Kiang, N., Koch, D., Lean, J., Lerner, J., Lo, K., Menon, S., Miller, R., Minnis, P., Novakov, T., Oinas, V., Perlwitz, Ja., Perlwitz, Ju., Rind, D., Romanou, A., Shindell, D., Stone, P., Sun, S., Tausnev, N., Thresher, D., Wielicki, B., Wong, T., Yao, M., and Zhang, S.: Efficacy of climate forcings, J. Geophys. Res., D18104, doi:10.1029/2005JD005776, 2005.

Hansen, M., DeFries, R., Townshend, J. R. G., and Sohlberg, R.: Global land cover classification at $1 \mathrm{~km}$ resolution using a decision tree classifier, Intern. J. Rem. Sensing., 21, 1331-1365, 2000.

Hegg, D. A., Radke, L. F., Hobbs, P. V., and Brock, C. A.: Nitrogen and sulfur emissions from the burning of forest products near large urban areas, J. Geophys. Res., 92, 14701-14709, 1987.

Hegg, D. A., Warren, S. G., Grenfell, T. C., Doherty, S. J., Larson, T. V., and Clarke, A. D.: Source attribution of black carbon in Arctic snow, Environ. Sci. Technol., 43, 4016-4021, doi:10.1021/es803623f, 2009.

Hegg, D. A., Warren, S. G., Grenfell, T. C., Doherty, S. J., and Clarke, A. D.: Sources of light-absorbing aerosol in arctic snow and their seasonal variation, Atmos. Chem. Phys., 10, 1092310938, doi:10.5194/acp-10-10923-2010, 2010.

Hirdman, D., Burkhart, J. F., Sodemann, H., Eckhardt, S., Jefferson, A., Quinn, P. K., Sharma, S., Ström, J., and Stohl, A.: Longterm trends of black carbon and sulphate aerosol in the Arctic: changes in atmospheric transport and source region emissions, Atmos. Chem. Phys., 10, 9351-9368, doi:10.5194/acp-10-93512010, 2010.

Holland, M. M., Serreze, M. C., and Stroeve, J.: The sea-ice mass budget of the Arctic and its future change as simulated by coupled climate models, Clim. Dyn., 34, doi:10.1007/s00382-0080493-4, 2010.

Holloway, J. S., Jakoubek, R. O., Parrish, D. D., Gerbig, C., VolzThomas, A., Schmitgen, S., Fried, A., Wert, B., Henry, B., and Drummond, J. R.: Airborne intercomparison of vacuum ultraviolet fluorescence and tunable diode laser absorption measurements of tropospheric carbon monoxide, J. Geophys. Res., 105, 24251-24261, 2000.

Hudson, P. K., Murphy, D. M., Cziczo, D. J.,. Thomson, D. S, de Gouw, J. A., Warneke, C., Holloway, J., Jost, H.-J., and Hübler G.: Biomass-burning particle measurements: Characteristic composition and chemical processing, J. Geophys. Res., 109, D2337, doi:10.1029/2003JD004398, 2004.

Huey, L. G., Tanner, D. J., Slusher, D. L., Dibb, J. E., Arimoto, R., Chen, G., Davis, D., Buhr, M. P., Nowak, J. B., Mauldin III, R. L., Eisele, F. L., and Kosciuch, E.: CIMS measurements of $\mathrm{HNO}_{3}$ and $\mathrm{SO}_{2}$ at the South Pole during ISCAT 2000, Atmos. Environ., 5411-5421, doi:10.1016/j.atmosenv.2004.04.037, 2004.

IPCC, Intergovernmental Panel on Climate Change: Climate Change 2007: The Physical Science Basis, Summary for Poli- cymakers, IPCC Secretariat, Geneva, Switzerland, available at: http://www.ipcc.ch, 2007.

Jacob, D. J., Crawford, J. H., Maring, H., Clarke, A. D., Dibb, J. E., Emmons, L. K., Ferrare, R. A., Hostetler, C. A., Russell, P. B., Singh, H. B., Thompson, A. M., Shaw, G. E., McCauley, E., Pederson, J. R., and Fisher, J. A.: The Arctic Research of the Composition of the Troposphere from Aircraft and Satellites (ARCTAS) mission: design, execution, and first results, Atmos. Chem. Phys., 10, 5191-5212, doi:10.5194/acp-10-5191-2010, 2010.

Jacobson, M. Z.: Climate response of fossil fuel and biofuel soot, accounting for soot's feedback to snow and seaice albedo and emissivity, J. Geophys. Res., 109, D21201, doi:10.1029/2004JD004945, 2004.

Jacobson, M. Z.: Short-term effects of controlling fossil-fuel soot, biofuel soot and gases, and methane on climate, Arctic ice, and air pollution health, J. Geophys. Res., 115, D14209, doi:10.1029/2009JD013795, 2010.

Janhäll, S., Andreae, M. O., and Pöschl, U.: Biomass burning aerosol emissions from vegetation fires: particle number and mass emission factors and size distributions, Atmos. Chem. Phys., 10, 1427-1439, 2010,

http://www.atmos-chem-phys.net/10/1427/2010/.

Johannessen, O. M., Bengtsson, L., Miles, M. W., Kuzmina, S. I., Semenov, V. A., Aledseev, G. V., Nagumyi, A. P., Zakharov, V. F., Bobylev, L. P., Pettersson, L. H., Hasselmann, K., and Cattle, H. P.: Arctic climate change: observed and modeled temperature and sea-ice variability, Tellus, 56A, 328-341, 2004.

Jonsson, H. H., Wilson, J. C., Brock, C. A., Knollenberg, R. G., Newton, R., Dye, J. E., Baumgardner, D., Borrmann, S., Ferry, G. V., Pueschel, R., Woods, D. C., and Pitts, M. C.: Performance of a focused cavity aerosol spectrometer for measurements in the stratosphere of particle size in the 0.06-2.0 $\mu \mathrm{m}$ diameter range, J. Ocean. Atmos. Technol., 12, 115-129, 1995.

Kanakidou, M., Seinfeld, J. H., Pandis, S. N., Barnes, I., Dentener, F. J., Facchini, M. C., Van Dingenen, R., Ervens, B., Nenes, A., Nielsen, C. J., Swietlicki, E., Putaud, J. P., Balkanski, Y., Fuzzi, S., Horth, J., Moortgat, G. K., Winterhalter, R., Myhre, C. E. L., Tsigaridis, K., Vignati, E., Stephanou, E. G., and Wilson, J.: Organic aerosol and global climate modelling: a review, Atmos. Chem. Phys., 5, 1053-1123, 2005,

http://www.atmos-chem-phys.net/5/1053/2005/.

Kawamura, K., Kasukabe, H, and Barrie, L. A., Source and reaction pathways of dicarboxylic acids, ketoacids and dicarbonyls in Arctic aerosols: one year of observations, Atmos. Environ., 20, 1709-1722, 1996.

King, W. D., Parkin, D. A., and Handsworth, R. J: A hot-wire water device having fully calculable response characteristics, J. Appl. Meteor., 17, 1809-1813, 1978.

Koch, D. and Hansen, J.: Distant origins of Arctic black carbon: A Goddard Institute for Space Studies ModelE experiment, J. Geophys. Res., 110, D04204, doi:10.1029/2004JD005296, 2005.

Kopacz, M., Jacob, D. J., Fisher, J. A., Logan, J. A., Zhang, L., Megretskaia, I. A., Yantosca, R. M., Singh, K., Henze, D. K., Burrows, J. P., Buchwitz, M., Khlystova, I., McMillan, W. W., Gille, J. C., Edwards, D. P., Eldering, A., Thouret, V., and Nedelec P.: Global estimates of CO sources with high resolution by adjoint inversion of multiple satellite datasets (MOPITT, AIRS, SCIAMACHY and TES), Atmos. Chem. Phys., 10, 855-876, 2010 , 
http://www.atmos-chem-phys.net/10/855/2010/.

Lance, S., Medina, J., Smith, J. N., and Nenes, A.: Mapping the operation of the DMT continuous flow CCN counter, Aerosol Sci. Technol., 40, 242-254, 2006.

Lance, S., Brock, C. A., Rogers, D., and Gordon, J. A.: Water droplet calibration of the Cloud Droplet Probe (CDP) and inflight performance in liquid, ice and mixed-phase clouds during ARCPAC, Atmos. Meas. Tech., 3, 1683-1706, doi:10.5194/amt3-1683-2010, 2010.

Lance, S., Shupe, M. D., Feingold, G., Brock, C. A., Cozic, J., Holloway, J. S., Moore, R. H., Nenes, A., Schwarz, J. P., Spackman, J. R., Froyd, K. D., Murphy, D. M., Brioude, J., Cooper, O. R., Stohl, A., and Burkhart, J. F.: Cloud condensation nuclei as a modulator of ice processes in Arctic mixed-phase clouds, Atmos. Chem. Phys. Discuss., 11, 6737-6770, doi:10.5194/acpd11-6737-2011, 2011.

Lavoué, D., Liousse, C., Cachier, H., Stocks, B., and Goldammer, J.: Modeling of carbonaceous particles emitted by boreal and temperate wildfires at northern latitudes, J. Geophys. Res., 105, 26871-26890, 2000.

Law, K. S. and Stohl, A.: Arctic air pollution: origins and impacts, Science, 315, 1537, doi:10.1126/science.1137695, 2007.

Li, S. M. and Winchester, J. W.: Geochemistry of organic and inorganic ions of late winter Arctic aerosols, Atmos. Environ., 23, 2401-2415, 1989.

Lindsay, R. W., Zhang, J., Schweiger, A., Steele, M., and Stern, H.: Arctic sea-ice retreat in 2007 follows thinning trend, J. Climate, 22, 165-176, 2009.

Lubin, D. and Vogelmann, A. M.: A climatologically significant aerosol longwave indirect effect in the Arctic, Nature Lett., 439, 2006.

Massoli, P., Bates, T. S., Quinn, P. K., Lack, D. A., Baynard, T., Lerner, B. M., Tucker, S. C., Brioude, J., Stohl, A., and Williams, E. J.: Aerosol optical and hygroscopic properties during TexAQS-GoMACCS 2006 and their impact on aerosol direct radiative forcing, J. Geophys. Res., 114, D00F07, doi:10.1029/2008JD011604, 2009.

Matthew, B. M., Middlebrook, A. M., and Onasch, T. B.: Collection efficiencies in an Aerodyne aerosol mass spectrometer as a function of particle phase for laboratory generated aerosols, Aerosol Sci. Technol., 42, 884, 884-898, doi:10.1080/02786820802356797, 2008.

McClatchey, R. A., Fenn, R. W., Selby, J. E. A., Volz, F. E., and Garing J. S.: Optical Properties of the Atmosphere, Air Force Cambridge Res. Lab., Hanscom A. F. B., Mass., available at: http://handle.dtic.mil/100.2/AD753075, 1972.

McComiskey, A., Schwartz, S. E., Schmid, B., Guan, H., Lewis, E. R., Ricchiazzi, P., and Ogren J. A.: Direct aerosol forcing: Calculation from observables and sensitivities to inputs, J. Geophys. Res., 113, D09202, doi:10.1029/2007JD009170, 2008.

McConnell, J. R., Edwards, R., Kok, G. L., Flanner, M. G., Zender, C. S., Saltzman, E. S., Banta, J. R., Pasteris, D. R., Carter, M. M., and Kahl, J. D. W.: 20th-century industrial black carbon emissions altered Arctic climate forcing, Science, 317, 1381-1384, doi:10.1126/science.1144856, 2007.

Mickley, L. J., Murti, P. P., Jacob, D. J., Logan, J. A., Rind, D., and Koch, D.: Radiative forcing from tropospheric ozone calculated with a unified chemistry-climate model, J. Geophys. Res., 104, 30, 153-30,172, 1999.
Montzka, S. A., Aydin, M., Battle, M., Butler, J. H., Saltzman, E. S., Hall, B. D., Clarke, A. D., Mondeel, D., and Elkins, J. W.: A 350-year atmospheric history for carbonyl sulfide inferred from Antarctic firn air and air trapped in ice, J. Geophys. Res., 109, D22302, doi:10.1029/2004JD004686, 2004.

Murphy, D. M., Cziczo, D. J., Froyd, K. D., Hudson, P. K., Matthew, B. M., Middlebrook, A. M., Peltier, R. E., Sullivan, A., Thomson, D. S., and Weber, R. J.: Single-particle mass spectrometry of tropospheric aerosol particles, J. Geophys. Res., 111, D23S32, doi:10.1029/2006JD007340, 2006.

NASA/University of Maryland. MODIS Hotspot/Active Fire Detections. Data set. MODIS Rapid Response Project, NASA/GSFC (producer), University of Maryland, Fire Information for Resource Management System (distributors), available at: http://maps.geog.umd.edu/firms/, 2002.

Neuman, J. A., Nowak, J. B., Huey, L. G., Burkholder, J. B., Dibb, J. E., Holloway, J. S., Liao, J., Peischl, J., Roberts, J. M., Ryerson, T. B., Scheuer, E., Stark, H., Stickel, R. E., Tanner, D. J., and Weinheimer, A.: Bromine measurements in ozone depleted air over the Arctic Ocean, Atmos. Chem. Phys., 10, 6503-6514, doi:10.5194/acp-10-6503-2010, 2010.

Noone, K. J. and Clarke, A. D.: Soot scavenging measurements in Arctic snowfall, Atmos. Environ., 22, 2773-2778, 1988.

Novelli, P. C., Steele, L. P., and Tans, P. P.: Mixing ratios of carbon monoxide in the troposphere, J. Geophys. Res., 97, 20,73120,750, doi:10.1029/92JD02010, 1992.

Novelli, P. C., Masarie, K. A., and Lang, P. M.: Distributions and recent changes in tropospheric carbon monoxide, J. Geophys. Res., 103, 19,015-19,033, doi:10.1029/98JD01366, 1998.

Ohtake, T., Jayaweera, K., and Sakurai, K.-I.: Observation of ice crystal formation in lower Arctic atmosphere, J. Atmos. Sci., 39, 2898-2904, 1982.

Olivier, J. G. J. and Berdowski, J. J. M.: Global emissions sources and sinks, in: The Climate System, A. A. Balkema/Swets \& Zeitlinger, Lisse, The Netherlands, ISBN 905809255 0, 33-78, 2001.

Ottar, B., Pacyna, J. M., and Berg, T.C.: Aircraft measurements of air pollution in the Norwegian Arctic, Atmos. Environ, 20, 87100, 1986.

Paris, J.-D., Stohl, A., Nédélec, P., Arshinov, M. Yu., Panchenko, M. V., Shmargunov, V. P., Law, K. S., Belan, B. D., and Ciais, P.: Wildfire smoke in the Siberian Arctic in summer: source characterization and plume evolution from airborne measurements, Atmos. Chem. Phys., 9, 9315-9327, doi:10.5194/acp-9-9315-2009, 2009.

Pavelsky, T. M., Boé, J., Hall, A., and Fetzer, E. J.: Atmospheric inversion strength over polar oceans in winter regulated by seaice, Clim. Dyn., 36, 945-955, doi:10.1007/s00382-010-0756-8, 2010.

Peischl, J., Ryerson, T. B., Holloway, J. S., Parrish, D. D., Trainer, M., Frost, G. J., Aikin, K. C., Brown, S. S., Dubé, W. P., Stark, H., and Fehsenfeld, F. C.: A top-down analysis of emissions from selected Texas power plants during TexAQS 2000 and 2006, J. Geophys. Res., 115, D16303, doi:10.1029/2009JD013527, 2010.

Peltier, R. E., Hecobian, A. H., Weber, R. J., Stohl, A., Atlas, E. L., Riemer, D. D., Blake, D. R., Apel, E., Campos, T., and Karl, T.: Investigating the sources and atmospheric processing of fine particles from Asia and the Northwestern United States measured during INTEX B, Atmos. Chem. Phys., 8, 183-5-1853, 
doi:10.5194/acp-8-1835-2008, 2008.

Pétron, G., Granier, C., Khattatov, B., Lamarque, J.-F., Yudin, V., Müller, J.-F., and Gille, J.: Inverse modeling of carbon monoxide surface emissions using Climate Monitoring and Diagnostics Laboratory network observations, J. Geophys. Res., 107, 4761, doi:10.1029/2001JD001305, 2002.

Petzold, A., Weinzierl, B., Huntrieser, H., Stohl, A., Real, E., Cozic, J., Fiebig, M., Hendricks, J., Lauer, A., Law, K., Roiger, A., Schlager, H., and Weingartner, E.: Perturbation of the European free troposphere aerosol by North American forest fire plumes during the ICARTT-ITOP experiment in summer 2004, Atmos. Chem. Phys., 7, 5105-5127, doi:10.5194/acp-7-51052007, 2007.

Pierce, R. B., Schaack, T. K., Al-Saadi, J., Fairlie, T. D., Kittaka, C., Lingenfelser, G., Natarajan, M., Olson, J., Soja, A., Zapotocny, T. H., Lenzen, A., Stobie, J., Johnson, D. R., Avery, M., Sachse, G., Thompson, A., Cohen, R., Dibb, J., Crawford, J., Rault, D., Martin, R., Szykman, J., and Fishman, J.: Chemical data assimilation estimates of continental US ozone and nitrogen budgets during INTEX-A, J. Geophys. Res., 112, D12S21, doi:10.1029/2006JD007722, 2007.

Pilewskie, P., Pommier, J., Bergstrom, R., Gore, W., Howard, S., Rabbette, M., Schmid, B., Hobbs, P. V., and Tsay, S. C.: Solar spectral radiative forcing during the Southern African Regional Science Initiative, J. Geophys. Res., 108(D13), 8486, doi:10.1029/2002JD002411, 2003.

Pueschel, R. and Kinne, S., Physical and radiative properties of Arctic atmospheric aerosols, Sci. Tot. Environ., 160-161, 811-824, doi:10.1016/0048-9697(95)04414-V, 1995.

Quinn, P. K., Miller, T. L., Bates, T. S., Ogren, J. A., Andrews, E., and Shaw, G. E.: A three-year record of simultaneously measured aerosol chemical and optical properties at Barrow, Alaska, J. Geophys. Res., 107, doi:10.1029/2001JD001248, 2002.

Quinn, P. K., Bates, T. S., Baynard, T., Clarke, A. D., Onasch, T. B., Wang, W., Rood, M. J., Andrews, E., Allan, J., Carrico, C. M., Coffman, D., and Worsnop, D.: Impact of particulate organic matter on the relative humidity dependence of light scattering: A simplified parameterization, Geophys. Res. Lett., 32, L22809, doi:10.1029/2005GL024322, 2005.

Quinn, P. K., Shaw, G., Andrews, E., Dutton, E. G. RuohoAirola, T., and Gong, S.: Arctic haze: Current trends and knowledge gaps, Tellus, 59, 99-114, doi:10.1111/j.16000889.2006.00238.x, 2007.

Quinn, P. K., Bates, T. S., Baum, E., Doubleday, N., Fiore, A. M., Flanner, M., Fridlind, A., Garrett, T. J., Koch, D., Menon, S., Shindell, D., Stohl, A., and Warren, S. G.: Short-lived pollutants in the Arctic: their climate impact and possible mitigation strategies, Atmos. Chem. Phys., 8, 1723-1735, doi:10.5194/acp8-1723-2008, 2008.

Quinn, P. K., Bates, T. S., Schulz, K., and Shaw, G. E.: Decadal trends in aerosol chemical composition at Barrow, Alaska: 19762008, Atmos. Chem. Phys., 9, 8883-8888, doi:10.5194/acp-98883-2009, 2009.

Raatz, W. E. and Shaw, G. E.: Long-range tropospheric transport of pollution aerosols into the Alaskan Arctic, J. Clim. Appl. Meteorol., 23, 1052-1064, 1984.

Radke, L. F., Lyons, J. H., Hegg, D. A., Hobbs, P. V., and Bailey, I. H.: Airborne observations of Arctic aerosols. I: Characteristics of Arctic haze, Geophys. Res. Lett., 11, 393-396
doi:10.1029/GL011i005p00393, 1984.

Rahn, K. A.: Relative importances of North America and Eurasia as sources of Arctic aerosol, Atmos. Environ., 15, 1447-1455, 1981.

Rahn, K. A., Borys, R. D., and Shaw, G. E.: The Asian source of Arctic haze bands, Nature, 268, 713-715, 1977.

Rahn, K. A. and McCaffery, R. J.: On the origin and transport of the winter Arctic aerosol, Ann. N. Y. Acad. Sci., 388, 486-503, 1980.

Reda, I., Hickey, J. R., Stoffel, T., and Meyers, D.: Pyrgeometer calibration at the National Renewable Energy Laboratory (NREL), J. Atmos. Terr. Phys., 64, 1623-1629, 2002.

Ricchiazzi, P., Yang, S., Gautier, C., and Sowle, D.: SBDART: A research and teaching software tool for plane-parallel radiative transfer in the Earth's atmosphere, Bull. Amer. Meteor. Soc., 79, 2101-2114, 1998.

Ritter, C., Notholt, J., Fischer, J., and Rathke, C.: Direct thermal radiative forcing of tropospheric aerosol in the Arctic measured by ground based infrared spectrometry, Geophys. Res. Lett., 32, L23816, doi:10.1029/2005GL024331, 2005.

Roberts, G. and Nenes, A.: A continuous-flow streamwise thermalgradient CCN chamber for atmospheric measurements, Aerosol Sci. Technol., 39, 206-221, 2005.

Ryerson, T. B., Buhr, M. P., Frost, G. J., Goldan, P. D., Holloway, J. S., Hübler, G., Jobson, B. T., Kuster, W. C., McKeen, S. A., Parrish, D. D., Roberts, J. M., Sueper, D. T., Trainer, M., Williams, J., and Fehsenfeld, F. C.: Emissions lifetimes and ozone formation in power plant plumes, J. Geophys. Res., 103, 22,56922,583, 1998.

Ryerson, T. B., Huey, L. G., Knapp, K., Neuman, J. A., Parrish, D. D., Sueper, D. T., and Fehsenfeld, F. C.: Design and initial characterization of an inlet for gas-phase $\mathrm{NO}_{\mathrm{y}}$ measurements from aircraft, J. Geophys. Res., 104, 5483-5492, 1999.

Ryerson, T. B., Williams, E. J., and Fehsenfeld, F. C.: An efficient photolysis system for fast-response $\mathrm{NO}_{2}$ measurements, J. Geophys. Res., 105, 26,447-26,461, 2000.

Saha, A., O’Neill, N. T., Eloranta, E., Stone, R. S., Eck, T. F., Zidane, S., Daou, D., Lupu, A., Lesins, G., Shiobara, M., and McArthur, L. J. B.: Pan-Arctic sunphotometry during the ARCTAS-A campaign of April 2008, Geophys. Res. Lett., 37, L05803, doi:10.1029/2009GL041375, 2010.

Scheuer, E., Talbot, R. W., Dibb, J. E., Seid, G. K., DeBell, L., and Lefer, B.: Seasonal distributions of fine aerosol sulfate in the North American Arctic basin during TOPSE, J. Geophys. Res., 108, 8370, doi:10.1029/2001JD001364, 2003.

Schnell, R. C.: Arctic haze and the Arctic Gas and Aerosol Sampling Program (AGASP), Geophys. Res. Lett. 11, 361-364, 1984.

Schwarz, J. P., Gao, R.-S., Fahey, D. W., Thomson, D. S., Watts, L. A., Wilson, J. C., Reeves, J. M., Darbehesti, M., Baumgardner, D. G., Kok, G. L., Chung, S. H., Schulz, M., Hendricks, J., Lauer, A., Kärcher, B., Slowik, J. G., Rosenlof, K. H., Thompson, R. L., Langford, A. O., Loewenstein, M., and Aikin, K. C. : Single-particle measurements of midlatitude black carbon and light-scattering aerosols from the boundary layer to the lower stratosphere, J. Geophys. Res., 111, D16207, doi:10.1029/2006JD007076, 2006.

Serreze, M. and Francis, J. A.: The Arctic amplification debate, Climatic Change, 76, 241-264, 2006. 
Sharma, S., Brook, J. R., Cachier, H., Chow, J., Gaudenzi, A., and Lu, G.: Light absorption and thermal measurements of black carbon in different regions of Canada, J. Geophys. Res., 107, 4771, doi:10.1029/2002JD002496, 2002.

Sharma, S., D. Lavoué, H. Cachier, L. A. Barrie, and S. L. Gong: Long-term trends of the black carbon concentrations in the Canadian Arctic, J. Geophys. Res., 109, D15203, doi:10.1029/2003JD004331, 2004.

Sharma, S., Andrews, E., Barrie, L. A., Ogren, J. A., and Lavoué, D.: Variations and sources of the equivalent black carbon in the high Arctic revealed by long-term observations at Alert and Barrow: 1989-2003, J. Geophys. Res., 111, D14208, doi:10.1029/2005JD006581, 2006.

Shaw, G. E.: The vertical distribution of atmospheric aerosols at Barrow, Alaska, Tellus 27, 39-49, 1975.

Shaw, P. M., Russell, L. M., Jefferson, A., and Quinn, P. K., Arctic organic aerosol measurements show particles from mixed combustion in spring haze and from frost flowers in winter, Geophys. Res. Lett., 37, L10803, doi:10.1029/2010GL042831, 2010.

Shindell, D. and Faluvegi, G.: Climate response to regional radiative forcing during the twentieth century, Nature Geosci., 2, 294 300, doi:10.1038/NGEO473, 2009.

Shindell, D. T., Chin, M., Dentener, F., Doherty, R. M., Faluvegi, G., Fiore, A. M., Hess, P., Koch, D. M., MacKenzie, I. A., Sanderson, M. G., Schultz, M. G., Schulz, M., Stevenson, D. S., Teich, H., Textor, C., Wild, O., Bergmann, D. J., Bey, I., Bian, H., Cuvelier, C., Duncan, B. N., Folberth, G., Horowitz, L. W., Jonson, J., Kaminski, J. W., Marmer, E., Park, R., Pringle, K. J., Schroeder, S., Szopa, S., Takemura, T., Zeng, G., Keating, T. J., and Zuber, A.: A multi-model assessment of pollution transport to the Arctic, Atmos. Chem. Phys., 8, 5353-5372, doi:10.5194/acp-8-5353-2008, 2008.

Slusher, D. L., Huey, L. G., Tanner, D. J., Flocke, F. M., and Roberts J. M.: A thermal dissociation-chemical ionization mass spectrometry (TD-CIMS) technique for the simultaneous measurement of peroxyacylnitrates and dinitrogen pentoxide, J. Geophys. Res., 109, D19315, doi:10.1029/2004JD004670, 2004.

Spackman, J. R., Gao, R. S., Neff, W. D., Schwarz, J. P., Watts, L. A., Fahey, D. W., Holloway, J. S., Ryerson, T. B., Peischl, J., and Brock, C. A.: Aircraft observations of enhancement and depletion of black carbon mass in the springtime Arctic, Atmos. Chem. Phys., 10, 9667-9680, doi:10.5194/acp-10-9667-2010, 2010.

Stark, H., Lerner, B. M., Schmitt, R., Jakoubek, R., Williams, E. J., Ryerson, T. B., Sueper, D. T., Parrish, D. D., and Fehsenfeld, F. C.: Atmospheric in situ measurement of nitrate radical $\left(\mathrm{NO}_{3}\right)$ and other photolysis rates using spectroradiometry and filter radiometry, J. Geophys. Res., 112, D10S04, doi:10.1029/2006JD007578, 2007.

Stohl, A., Eckhardt, S., Forster, C., James, P., and Spichtinger, N.: On the pathways and timescales of intercontinental air pollution transport, J. Geophys. Res. 107, 4684, doi:10.1029/2001JD001396, 2002.

Stohl, A., Forster, C., Eckhardt, S., Spichtinger, N., Huntrieser, H., Heland, J., Schlager, H., Wilhelm, S., Arnold, F., and Cooper, O.: A backward modeling study of intercontinental pollution transport using aircraft measurements. J. Geophys. Res., 108, 4370, doi:10.1029/2002JD002862, 2003.

Stohl, A., Forster, C., Frank, A., Seibert, P., and Wotawa,
G.: Technical note: The Lagrangian particle dispersion model FLEXPART version 6.2, Atmos. Chem. Phys., 5, 2461-2474, doi:10.5194/acp-5-2461-2005, 2005.

Stohl, A.: Characteristics of atmospheric transport into the Arctic troposphere, J. Geophys. Res., 111, D11306, doi:10.1029/2005JD006888, 2006.

Stohl, A., Andrews, E., Burkhart, J. F., Forster, C., Herber, A., Hoch, S. W., Kowal, D., Lunder, C., Mefford, T., Ogren, J. A., Sharma, S., Spichtinger, M., Stebel, K., Stone, R., Ström, J., Tørseth, K., Wehrli, C., and Yttri, K. E.: Pan-Arctic enhancements of light absorbing aerosol concentrations due to North American boreal forest fires during summer 2004, J. Geophys. Res., 111, D22214, doi:10.1029/2006JD007216, 2006.

Stohl, A., Berg, T., Burkhart, J. F., Fj?raa, A. M., Forster, C., Herber, A., Hov, Ø., Lunder, C., McMillan, W. W., Oltmans, S., Shiobara, M., Simpson, D., Solberg, S., Stebel, K., Ström, J., Tørseth, K., Treffeisen, R., Virkkunen, K., and Yttri, K. E.: Arctic smoke - record high air pollution levels in the European Arctic due to agricultural fires in Eastern Europe in spring 2006, Atmos. Chem. Phys., 7, 511-534, doi:10.5194/acp-7-511-2007, 2007.

Stone, R. S., Anderson, G. P., Andrews, E., Dutton, E. G., Shettle, E. P., and Berk, A.: Incursions and radiative impact of Asian dust in northern Alaska, Geophys. Res. Lett., 34, L14815, doi:10.1029/2007GL029878, 2007.

Stone, R. S., Anderson, G. P., Shettle, E. P., Andrews, E., Loukachine, K., Dutton, E. G., Schaaf, C., and Roman III, M. O.: Radiative impact of boreal smoke in the Arctic: Observed and modeled, J. Geophys. Res., 113, D14S16, doi:10.1029/2007JD009657, 2008.

Stone, R., S., Herber, A., Vitale, V., Mazzola, M., Lupi, A., Schnell, R. C., Dutton, E. G., Liu, P. S. K., Li, S.-M., Dethloff, K., Lampert, A., Ritter, C., Stock, M., Neuber, R., and Maturilli, M.: A three-dimensional characterization of Arctic aerosols from airborne Sun photometer observations: PAM-ARCMIP, April 2009, J. Geophys. Res., 115, D13203, doi:10.1029/2009JD013605, 2010.

Stroeve, J., Holland, M. M., Meier, W., Scambos, T., and Serreze, M. C.: Arctic sea-ice decline: faster than forecast, Geophys. Res. Lett., 34, L09501, doi:10.1029/2007GL029703, 2007.

Strunin, M. A., Postnov, A. A., and Mezrin, M. Y, Meteorological potential for contamination of arctic troposphere: Boundary layer structure and turbulent diffusion characteristics, Atmos. Res, 44, 37-51, 1997.

Toon, O. B., Pollack, J. B., and Khare B. N.: The optical constants of several atmospheric aerosol species: ammonium sulfate, aluminum oxide, and sodium chloride, J. Geophys. Res., 81(33), 5733-5748, 1976.

Treffeisen, R., Tunved, P., Ström, J., Herber, A., Bareiss, J., Helbig, A., Stone, R. S., Hoyningen-Huene, W., Krejci, R., Stohl, A., and Neuber, R.: Arctic smoke - aerosol characteristics during a record smoke event in the European Arctic and its radiative impact, Atmos. Chem. Phys., 7, 3035-3053, doi:10.5194/acp-73035-2007, 2007.

Tjernström, M. and Graversen, R. G.: The vertical structure of the lower Arctic troposphere analysed from observations and the ERA-40 reanalysis, Q. J. R. Meteorol. Soc., 135, 431-443, doi:10.1002/qj.308, 2009.

Turpin, B. J. and Lim, H.-J.: Species contributions to $\mathrm{PM}_{2.5}$ 
mass concentrations: Revisiting common assumptions for estimating organic mass, Aerosol Sci. Technol., 35, 602-610, doi:10.1080/02786820119445, 2001.

Vowinckel, E. and Orvig, S.: The climate of the North Polar Basin, in: World Survey of Climatology, Vol. 14: Climates of the Polar Regions, Elsevier, New York, USA, 129-252, 1970.

Walsh, J. E., Kattsov, V. M., Chapman, W. L., Govorkova, V., and Pavlova, T.: Comparison of Arctic climate simulations by uncoupled and coupled global models, J. Clim., 15, 1429-1446, 2002.

Wang, M., Overland, J. E., Kattsov, V., Walsh, J. E., Zhang, X., and Pavlova, T.: Intrinsic versus forced variation in coupled climate model simulations over the Arctic during the twentieth century, J. Clim., 20, 1093-1107, doi:10.1175/JCLI4043.1, 2007.

Warneke, C., Bahreini, R., Brioude, J., Brock, C. A., de Gouw, J. A., Fahey, D. W., Froyd, K. D., Holloway, J. S., Middlebrook, A., Miller, L., Montzka, S., Murphy, D. M., Peischl, J., Ryerson, T. B., Schwarz, J. P., Spackman, J. R., and Veres, P.: Biomass burning in Siberia and Kazakhstan as an important source for haze over the Alaskan Arctic in April 2008, Geophys. Res. Lett., 36, L02813, doi:10.1029/2008GL036194, 2009.

Warneke, C., Froyd, K. D., Brioude, J., Bahreini, R., Brock, C. A., Cozic, J. , de Gouw, J. A., Fahey, D. W., Ferrare, R., Holloway, J. S., Middlebrook, A. M., Miller, L., Montzka, S., Schwarz, J. P., Sodemann, H. , Spackman, J. R., and Stohl A.: An important contribution to springtime Arctic aerosol from biomass burning in Russia, Geophys. Res. Lett., 37, L01801, doi:10.1029/ 2009GL041816, 2010.
Wilson, J. C., Lafleur, B. G., Hilbert, H., Seebaugh, W. R., Fox, J., Gesler, D. W., Brock, C. A., Huebert, B. J., and Mullen, J.: Function and performance of a low turbulence inlet for sampling super-micron particles from aircraft platforms, Aerosol Sci. Technol., 38, 790-802, 2004.

Winton, M.: Amplified Arctic climate change: What does surface albedo feedback have to do with it?, Geophys. Res. Lett., 33, L03701, doi:10.1029/2005GL025244, 2006.

Yttri, K. E., Dye, C., Braathen, O.-A., Simpson, D., and Steinnes, E.: Carbonaceous aerosols in Norwegian urban areas, Atmos. Chem. Phys., 9, 2007-2020, doi:10.5194/acp-9-2007-2009, 2009.

Zhang, Q., Worsnop, D. R., Canagaratna, M. R., and Jimenez, J. L.: Hydrocarbon-like and oxygenated organic aerosols in Pittsburgh: insights into sources and processes of organic aerosols, Atmos. Chem. Phys., 5, 3289-3311, doi:10.5194/acp-5-32892005, 2005. 